\title{
Geothermal Resource Assessment of Western San Luis Valley, Colorado
}

by

Ted G. Zacharakis

Richard Howard Pearl Garles D. Ringrose

$00000000 \%$

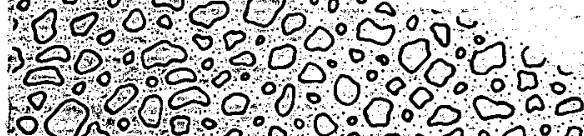
0.000000000000000

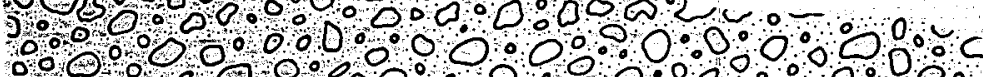

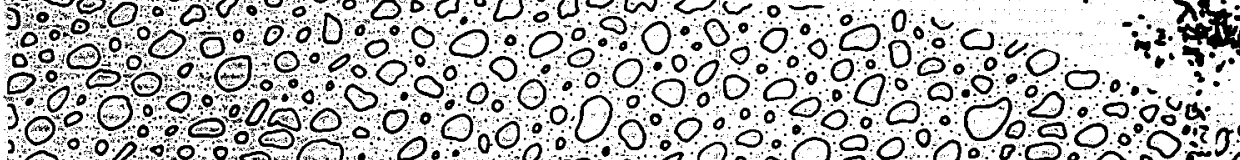

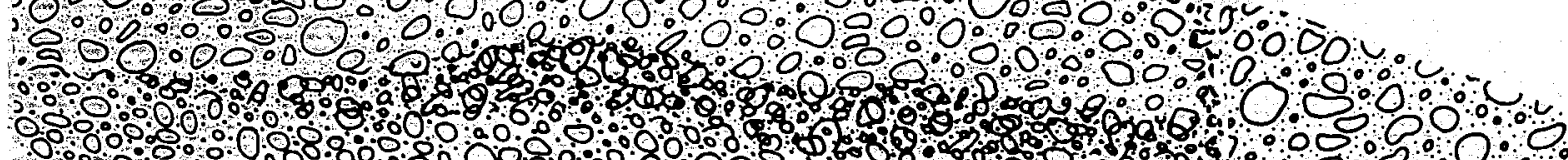

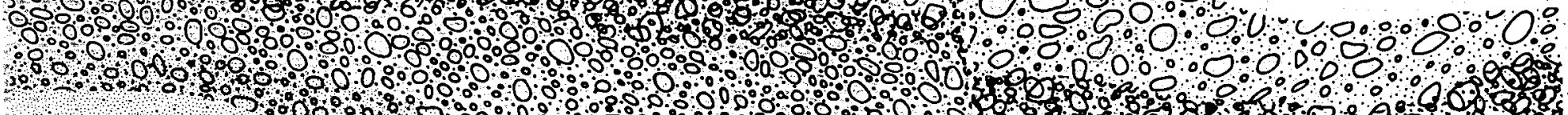

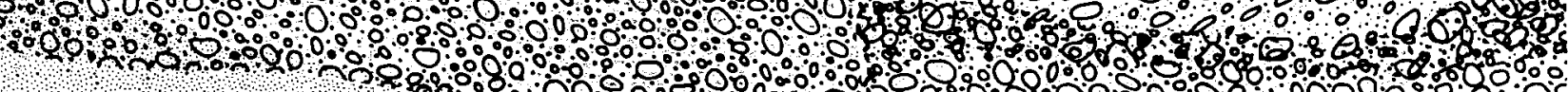

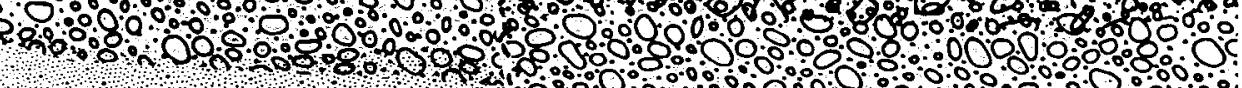

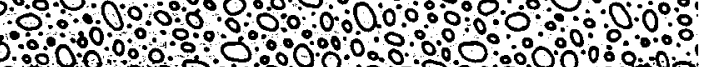


l.


Colorado Geological Survey / Department of Natural Resources / Denver, Colorado / 1983 


\section{DISCLAIMER}

This report was prepared as an account of work sponsored by an agency of the United States Government. Neither the United States Government nor any agency Thereof, nor any of their employees, makes any warranty, express or implied, or assumes any legal liability or responsibility for the accuracy, completeness, or usefulness of any information, apparatus, product, or process disclosed, or represents that its use would not infringe privately owned rights. Reference herein to any specific commercial product, process, or service by trade name, trademark, manufacturer, or otherwise does not necessarily constitute or imply its endorsement, recommendation, or favoring by the United States Government or any agency thereof. The views and opinions of authors expressed herein do not necessarily state or reflect those of the United States Government or any agency thereof. 


\section{DISCLAIMER}

Portions of this document may be illegible in electronic image products. Images are produced from the best available original document. 


\title{
RESOURCE SERIES 19
}

GEOTHERMAL RESOURCE ASSESSMENT OF WESTERN SAN LUIS VALLEY, COLORADO

by

Ted G. Zacharakis, Richard Howard Pearl and Charles D. Ringrose

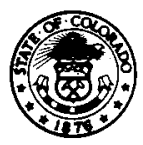

\author{
Prepared by the \\ COLORADO GEOLOGICAL SURVEY \\ in cooperation with the \\ U.S. Dept. of Energy \\ Under Contract No. DE-AS07-77ET28365
}

Colorado Geological Survey

Department of Natural Resources

State of Colorado

Denver, Colorado

1983 


\section{NOTICE}

This report was prepared to document work sponsored by the United States Government. Neither the United States nor its agent the United States Department of Energy, nor any Federal Employees, nor any of their contractors, subcontractors or their employees, makes any warranty, express or implied, or assumes any legal liability or responsibility for the accuracy, completeness, - or usefulness of any information, apparatus, product or process disclosed, or represents that its use would infringe privately owned rights.

\section{NOTICE}

Reference to a company product name does not imply approval or recommendation of the product by the Colorado Geological Survey nor the U.S. Department of Energy to the exclusion of others that may be suitable.

\section{ACKNOWLEDGMENTS}

The authors are very grateful for the assistance of the following competent individuals: Jay Jones, geophysical survey field crew chief; Bob Fargo and Chuck Treska, geophysical field assistants; Michael Glaze, geochemical field crew chief, and his assistants Deborah Wester and James Ross: Becky Nelson, typist; and Cheryl Brchan, who patiently drafted the figures.

We deeply appreciate the time and effort expended by Dr. Duncan Foley and his colleagues at the Earth Science Laboratory, University of Utah Reasearch Institute who reviewed the manuscript. However, all findings and conclusions are the responsibility of the authors. 
Acknowledgments

Abstract

Introduction

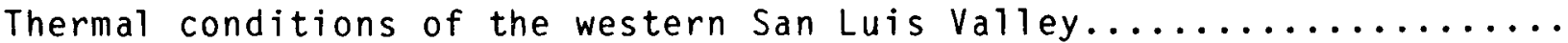

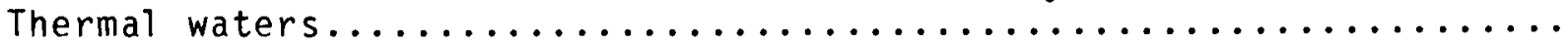

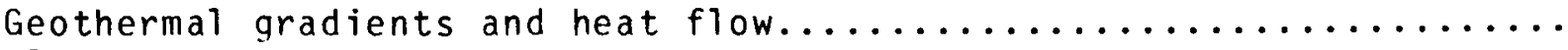

Geology.

Introduction.

Stratigraphy.



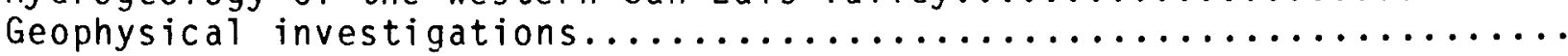

Introduction.

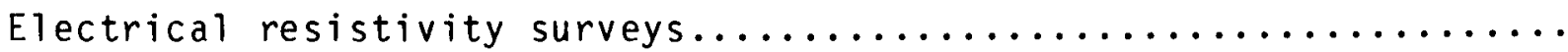

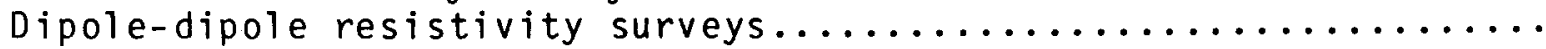

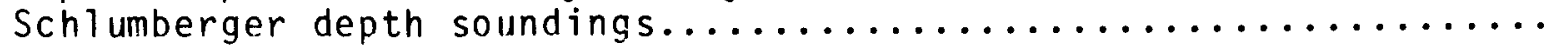

Audio-magnetotelluric and telluric surveys ...................

Geophysical surveys conducted by the Colorado School of Mines.......

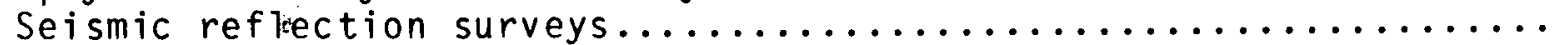

Time-domain electromgnetic sounding surveys $\ldots \ldots \ldots \ldots \ldots \ldots \ldots \ldots$

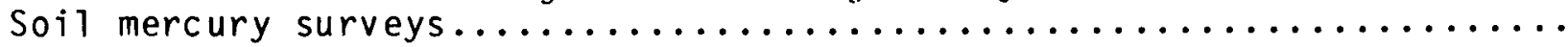

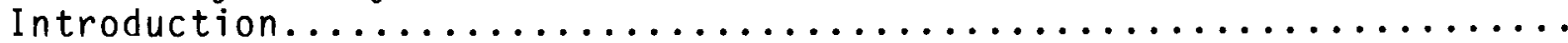

Soil mercury survey in the Shaw Warm Springs area.................

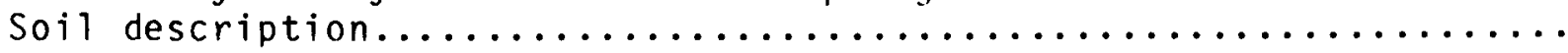

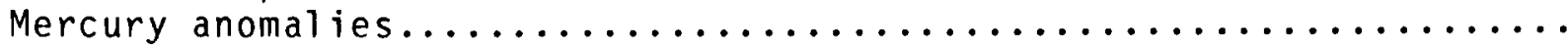

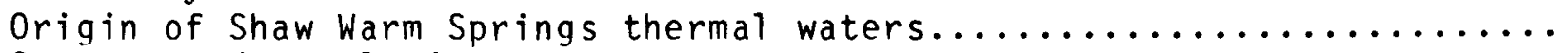

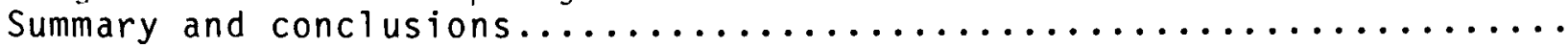

References.



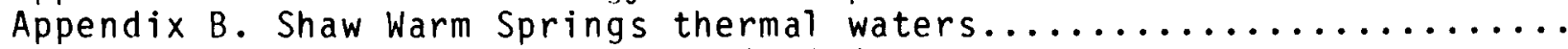

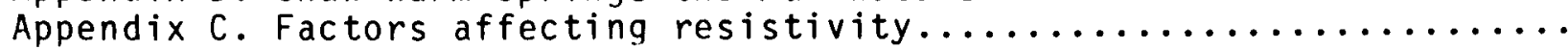

Appendix D. Scintrex RAC-8 low frequency resistivity system..........



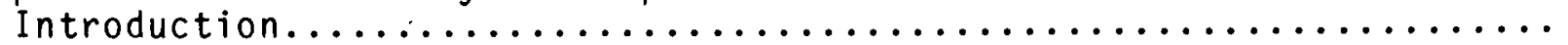

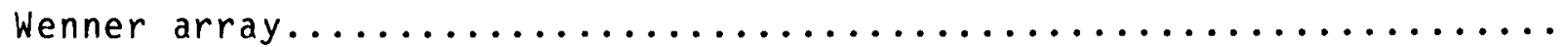

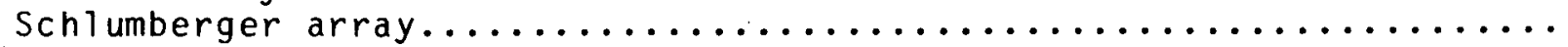

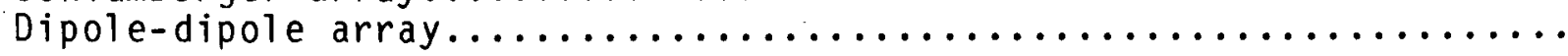

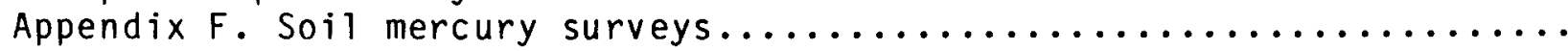

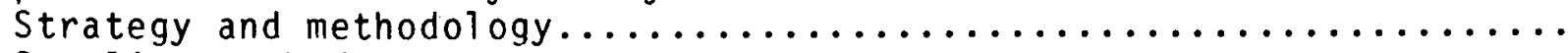



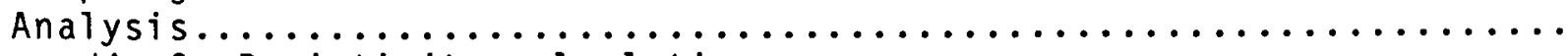



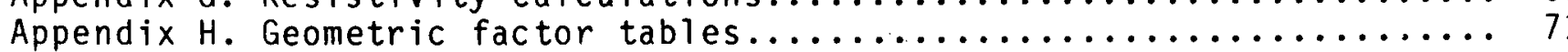



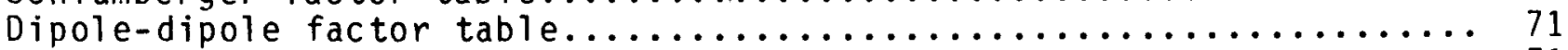




Figure 1. Index $\operatorname{map}$ of Colorado........................ 2

Figure 2. Physiographic subdivisions of the San Luis Valley..........

Figure 3.

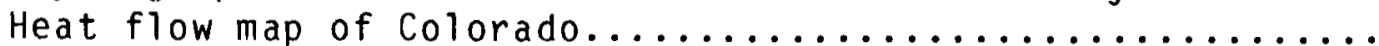

Figure 4.

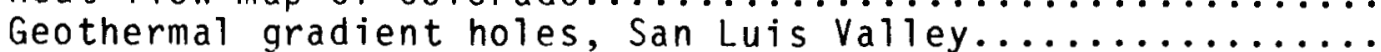

Figure 5 .

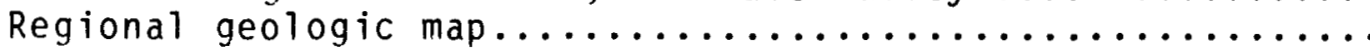

Figure 6 .

Location of dipole-dipole resistivity survey, western

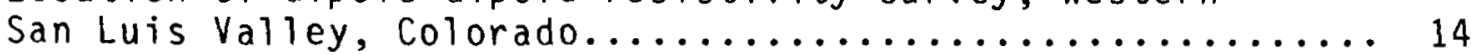

Figure 7 .

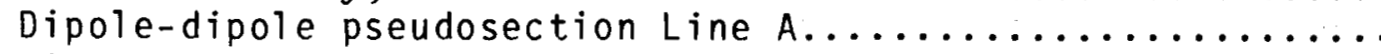

Figure 8 .

Dipole-dipole pseudosection Line B.

Figure 9 .

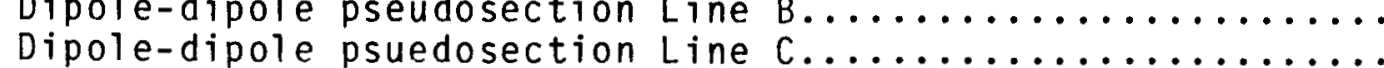

Figure 10 .

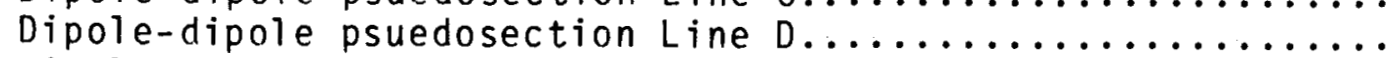

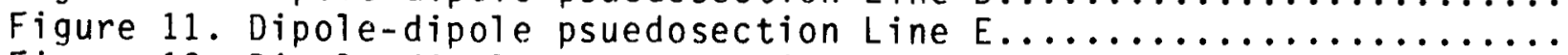

Figure 12. Dipole-dipole psuedosection Line $F \ldots \ldots \ldots \ldots \ldots \ldots \ldots \ldots$

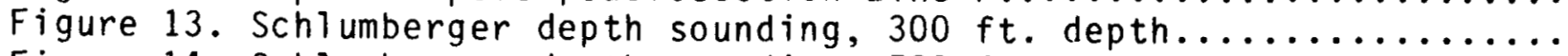

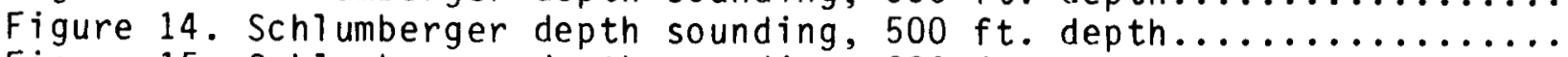

Figure 15. Schlumberger depth sounding, $900 \mathrm{ft}$. depth.............

Figure 16. Telluric profile location map and generalized geology of

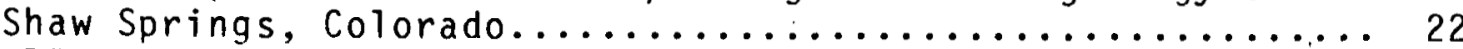

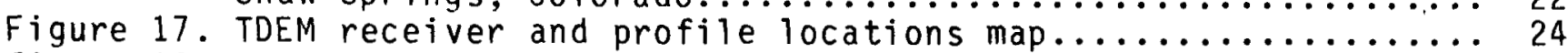

Figure 18. East-west time-domain electromagnetic sounding cross-sec.... 25

Figure 19. North-south time-domain electromagnetic sounding cross-sec.. 25

Figure 20. Location, soil mercury lines, Shaw Warm Springs........... 27

Figure 21. Shaw Warm Springs, Colorado soil mercury histogram........ 28

Figure 22. Shaw Springs, Colorado geothermal resource area map........ 33

Figure 23. Temperature range for some direct uses of geothermal energy. 40

Figure 24 . Schematic diagram for resistivity.................. 46

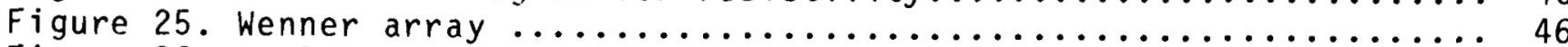

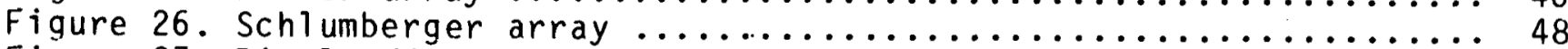

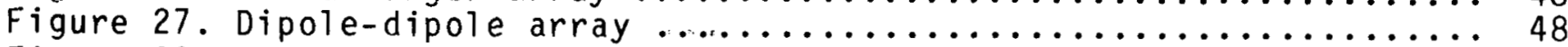

Figure 28. Data plotting scheme for dipole-dipole array ........... 49

Figure 29. Typical dipole-dipole array .................... 49

\section{TABLES}

1. Stratigraphic section, western San Luis Valley............... 9



3. Analytical mercury values, Shaw Warm Springs area.............. 29

4. Physical properties and chemical analysis of Shaw Warm Springs.... 41

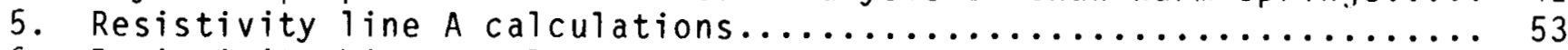

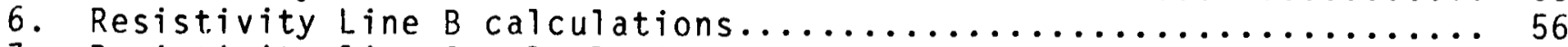

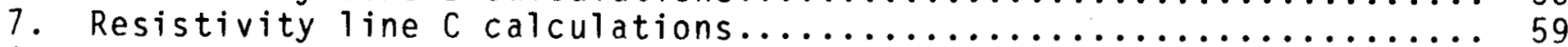

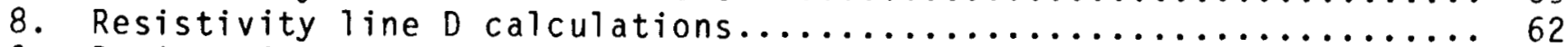

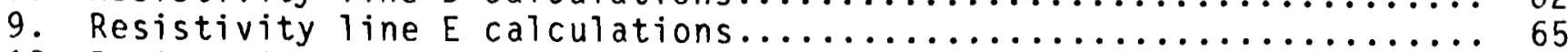

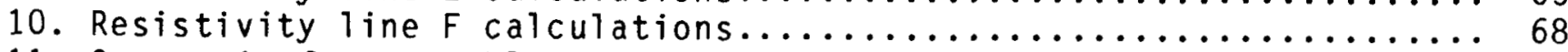

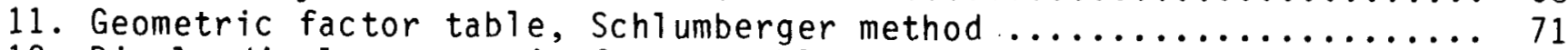



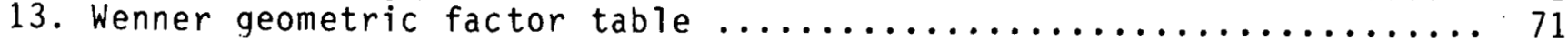


GEOTHERMAL RESOURCE ASSESSMENT OF WESTERN SAN LUIS VALLEY, COLORADO by

Ted G. Zacharakis, Richard Howard Pearl and Charles D. Ringrose

\section{ABSTRACT}

The Colorado Geological Survey initiated and carried out a fully integrated assessment program of the geothermal resource potential of the western San Luis Valley during 1979 and 1980. The San Luis Valley is a large intermontane basin located in southcentral Colorado. While thermal springs and wells are found throughout the Valley, the only thermal waters found along the western part of the Valley are found at Shaw Warm Springs which is a relatively unused spring located approximately 6 miles $(9.66 \mathrm{~km})$ north of Del Norte, Colorado. The waters at Shaws Warm Spring have a temperature of $86^{\circ} \mathrm{F}\left(30^{\circ} \mathrm{C}\right)$, a discharge of $40 \mathrm{gallons}$ per minute and contain approximately $408 \mathrm{mg} / 1$ of total dissolved solids.

The assessment program carried out in the western San Luis Valley consisted of: soil mercury geochemical surveys; geothermal gradient drilling; and dipole-dipole electrical resistivity traverses, Schlumberger soundings, Audio-magnetotelluric surveys, telluric surveys, and time-domain electromagnetic soundings and seismic surveys.

Shaw Warm Springs appears to be the only source of thermal waters along the western side of the valley. From the various investigations conducted the springs appear to be fault controlled and is very limited in extent.

Based on best evidence presently available estimates are presented on the size and extent of Shaw Warm Springs thermal system.. It is estimated that this could have an areal extent of $0.63 \mathrm{sq}$. miles $(1.62 \mathrm{sq} . \mathrm{km})$ and contain 0.0148 $Q$ 's of heat energy.

\section{INTRODUCTION}

In 1979, the Colorado Geological Survey, in cooperation with the U.S. Department of Energy, Division of Geothermal Energy, under Contract No. DE-AS07-77ET28365, initiated a program designed to determine the nature and extent of Colorado's geothermal resources. Priority was given to those areas with the greatest potential for near term development. The areas evaluated under this program were The Animas Valley north of Durango, Canon City Area, Hartsel Hot Springs, Hot Sulphur Springs, Idaho Springs, Ouray, Ranger Hot Springs, the Steamboat Springs-Routt Hot Springs area, and the western San Luis valley in the vicinity of Shaw Warm Springs. This publication reports the findings of the resource assessment program carried out in the area surrounding Shaw Warm Springs in the western San Luis Valley (Fig. 1). As the geological conditions controlling the occurrence of Shaws Warm Spring were not apparent, a multi-faceted exploration program was conducted. The program consisted of literature search, reconnaisance geologic and hydrogeological mapping, geophysical surveys, soil mercury geochemical surveys, and determination of the geothermal gradient of the area. 


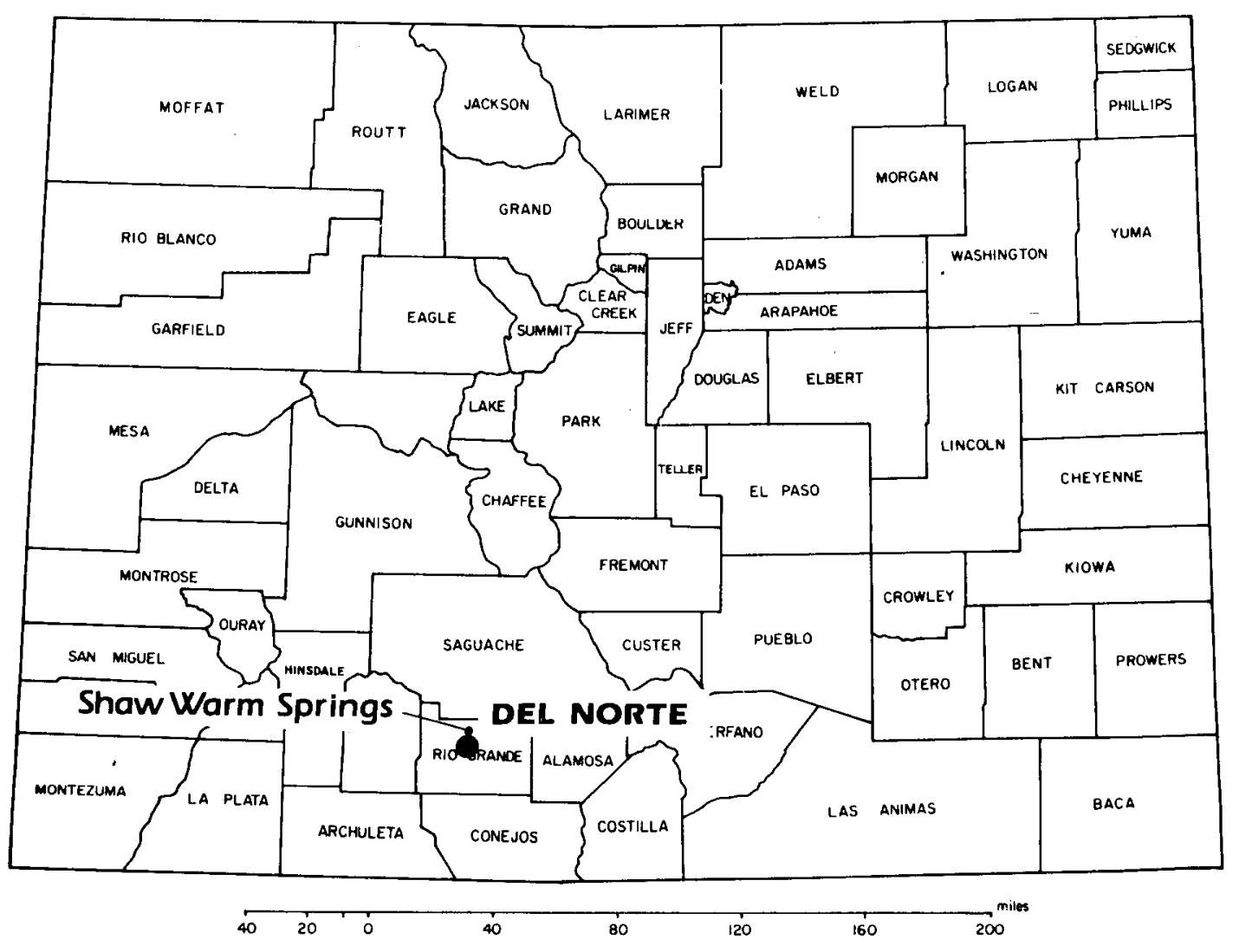

Figure 1. Index map.

The San Luis Valley of southcentral Colorado is a large intermontane basin having an average altitude of approximately $7,600 \mathrm{ft}(2.32 \mathrm{~km})$ above sea 1 evel. Principal industries of the Valley are agriculture, agricultural product processing and mining (Coe, 1980). The San Luis Valley is an energy poor region with $45 \%$ of its electrical energy and $100 \%$ of its petroleum products being imported (Coe, 1980). In her in-depth assessment of the energy needs and consumption in the San Luis Valley, Coe (1980) noted that due to a moratorium on new gas taps, many of the residents of the valley were forced to turn to expensive electricity or propane for heat in the $1970 \mathrm{~s}$. She pointed out that a possible source of energy that could be used to help alleviate the growing energy needs of the Valley is geothermal energy. According to Coe's (1980) calculations, the geothermal resources of the valley have the potential for 
supplying annually more than 2 times the amount of natural gas consumed throughout the Valley in 1977. Mainfestations of geothermal energy in the form of hot water (hydrothermal) springs are found throughout the Valley. From north to south, these hydrothermal areas are: Mineral Hot Springs; Valley View Warm Springs; Sand Dunes Swimming Pool Hot Water Well; Shaw Warm Springs; the Alamosa area; and Dexter and McIntyre Warm Springs. Temperatures of the thermal waters found in the valley range from a low of $68^{\circ} \mathrm{F}\left(20^{\circ} \mathrm{C}\right)$ to a high of $140^{\circ} \mathrm{F}\left(60^{\circ} \mathrm{C}\right)$.

During the last 10 years various aspects of the geothermal resources of the San Luis Valley have been discussed by numerous authors. Some of these papers were authored by: Barrett and Pearl (1976 and 1978); Burroughs (1981); Coe (1980); Coury and Vorum (1978); Goering and Connor (1980); Goering and others (1979a, $1979 \mathrm{~b}$, and 1980); Harder and others (1980); Jordan (1974); Meyer and Roberts (1979); Pearl (1972 and 1979); Pearl and Barrett (1976); Romero and Fawcett (1978); and Vorum and others (1978).

Geothermal energy, the natural heat of the earth, is a source of energy that can, under favorable conditions, be put to a wide range of uses. Under normal conditions geothermal energy is either too diffuse or found at depths too great to be of practical value. In those instances where geothermal energy occurs close to the surface it can be developed and put to practical use. Techniques and equipment for developing and using geothermal energy are readily available today. A brief description of geothermal energy and some of its possible uses are presented in Appendix A. 
Thermal Waters

A number of thermal springs and well s whose water temperatures are in excess of $68^{\circ} \mathrm{F}\left(20^{\circ} \mathrm{C}\right)$ are $10 \mathrm{cated}$ in the San Luis Valley. However, the only thermal waters in the western part of the San Luis Valley are found at Shaw Warm Springs. This are small relatively unused thermal springs located approximately $6 \mathrm{mi}(9.66 \mathrm{~km})$ north of Del Norte, Colorado and $5 \mathrm{mi}(8.05 \mathrm{~km})$ southeast of the Summer Coon volcanic area on the eastern slope of the San Juan Mountains (Fig. $2)$. The waters of Shaw Warm Springs have a temperature of $86^{\circ} \mathrm{F}\left(30^{\circ} \mathrm{C}\right)$, an annual average discharge of 40 gallons per minute (gpm) and contain approximately $408 \mathrm{mg} / 1$ of total dissolved solids. Historically the thermal waters have only been used by the owner for recreational purposes (Barrett and Pear 1, 1978). Chemical analysis of the Shaw Warm Springs waters is presented in Appendix B.

\section{Geothermal Gradients and Heat Flow}

Only one true heat-flow hole has been drilled along the western side of the San Luis valley. Calculations from measurements made in this well, located approximately 3 miles $(4.8 \mathrm{Km})$ north of Shaw Warm Springs, determined that the corrected heat flow for the area is $113 \mathrm{~mW} / \mathrm{m} 2$ (Decker and Bucher, 1979). Based on regional data, Zacharakis (1981) has shown that the heat flow of the Western San Luis Valley ranges from 1 ess than $100 \mathrm{~mW} / \mathrm{m} 2$ to over $120 \mathrm{~mW} / \mathrm{M} 2$

(Fig. 3).

During the winter of 1979-80, 16 temperature gradient holes were drilled throughout the central part of the San Luis Valley (Fig. 4). The depth of these holes ranged up to $300 \mathrm{ft}(91.4 \mathrm{~m})$ (Ringrose, 1980). In order that a complete and representive measurement of the geothermal gradients be made, unperforated, two-inch diameter, black iron pipe was installed in the holes to total depth. The annular space was backfilled with drill cuttings to within $3-4$ $\mathrm{ft}(1-1.2 \mathrm{~m})$ of the surface on which a cement grout seal extending to the surface was placed. The pipe was filled with water and allowed a minimum of two weeks to reach equilibrium temperature conditions before temperature measurements were made (Ringrose, 1980). As shown in Figure 4, gradients measured in these holes ranged from $1.62^{\circ} \mathrm{F} / 100 \mathrm{ft}\left(29.6^{\circ} \mathrm{C} / \mathrm{km}\right)$ to a high of $4.1^{\circ} \mathrm{F} / 100 \mathrm{ft}\left(74.7^{\circ} \mathrm{C} / \mathrm{km}\right)$. The average geothermal gradient for these 16 holes was $3.17^{\circ} \mathrm{F} / 100 \mathrm{ft}\left(57.8^{\circ} \mathrm{C} / \mathrm{km}\right)$. A Fluid Dynamics temperature probe calibrated to an accuracy of $+0.1^{\circ} \mathrm{C}$ with a resolution of at least $.01^{\circ} \mathrm{C}$ was used to measure the temperatures in the holes (Ringrose, 1980). 


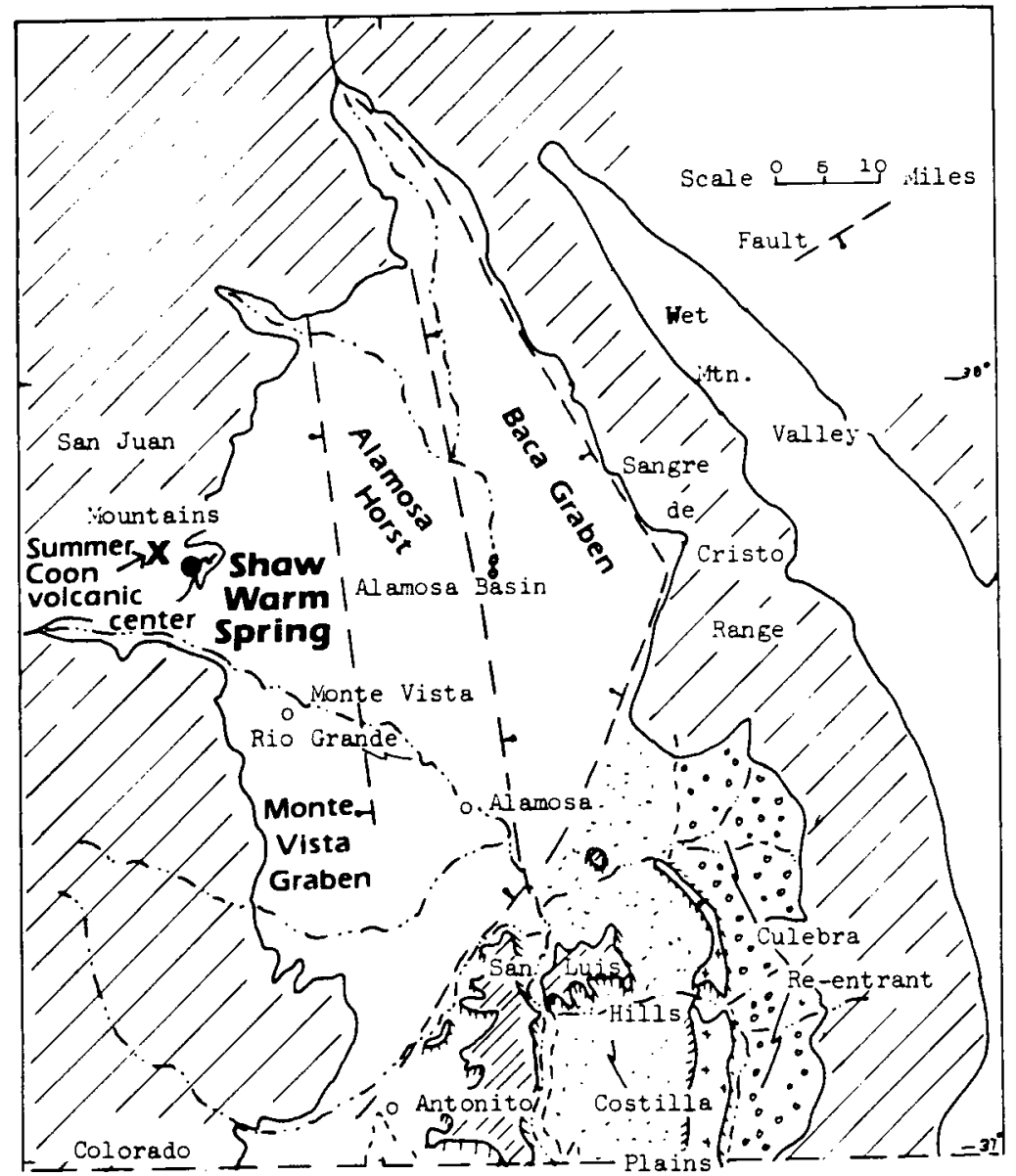

Figure 2. Physiographic subdivisions, San Luis Valley (modified from Burroughs, 1981).

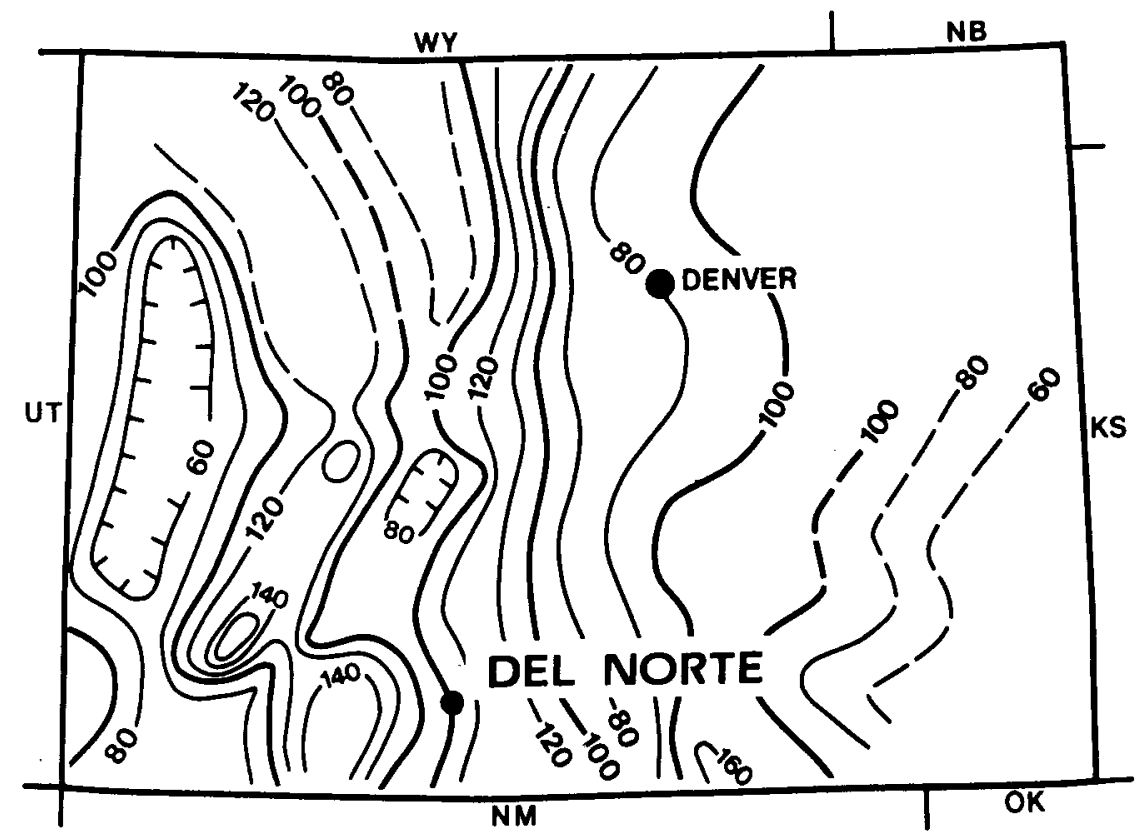

Figure 3. Heat flow map of Colorado (from Zacharakis, 1981). 


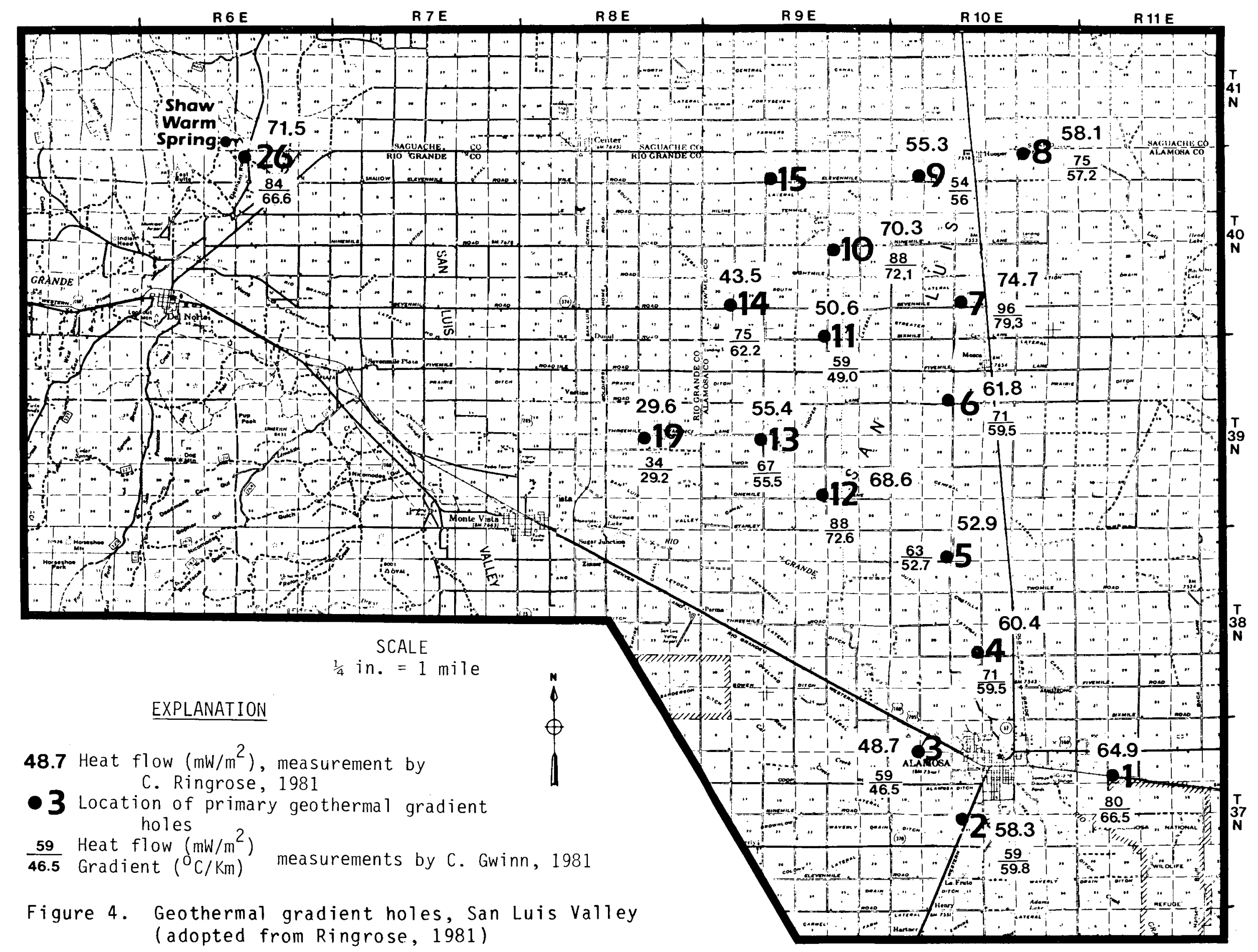


During the summer of 1981, Ms. Cindy Gwinn (Southern Methodist University), remeasured the temperatues in these holes and calculated both the geothermal gradient and heat flow. Her measurments showed that the gradients ranged from $1.24^{\circ} \mathrm{F} / 100 \mathrm{ft}(22.6 \mathrm{C} / \mathrm{km})$ to $4.35^{\circ} \mathrm{F} / 100 \mathrm{ft}\left(79.3^{\circ} \mathrm{C} / \mathrm{km}\right)$ with an average gradient of $3.34^{\circ} \mathrm{F} / 100 \mathrm{ft}\left(59.0^{\circ} \mathrm{C} / \mathrm{km}\right)$ ( $\left.\mathrm{Fig} .4\right)$ (Gwinn, 1981 ).

Using bottom hole temperature measurements from $0 i 1$ wells, plus other data, Reppiier and Fargo (1981) have shown that the regional gradient in the western San Luis Valley is approximately $2.2^{\circ} \mathrm{F} / 100 \mathrm{ft}\left(40^{\circ} \mathrm{C} / \mathrm{km}\right)$.

Gwinn (1981), determined that the heat-flow in the gradient holes she remeasured ranged from $34 \mathrm{~mW} / \mathrm{m} 2$ to $96 \mathrm{~mW} / \mathrm{m} 2$ (Fig. 4), with an average heat flow of $70.5 \mathrm{~mW} / \mathrm{m} 2$. Due to the large number of variables including shallow depth of holes, ground-water movement, and assumed conductivity of sediments which could be influencing the temperature measurements, her results are in fairly close agreement with other published data. 


\section{GEOLOGY}

\section{Introduction}

The following discussion is taken from Burroughs (1981); Chapin, (1979) and Tweto (1975 and 1979) although Corde11, 1978; James, 1971; and Riecker, 1979 have al so published on various aspects of the geological conditions of the valley and its immediate surroundings.

The San Luis Valley is part of the larger Rio Grande Rift Zone, which extends from southern New Mexico northward through the San Luis and upper Arkansas Valleys, and terminates about 12 miles $(19 \mathrm{~km})$ north of Leadville, Colorado. The Valley, which opens southward into New Mexico, is bounded on three sides by mountain ranges: The Sangre de Cristo Range on the east and north; and the San Juan Mountains on the west and northwest (Fig. 2).

Along the east side of the valley block faulting has brought Precambrian age rocks of the Sangre de Cristo Mountains up into contact with the Tertiary age rocks of the valley. On the west side of the valley 01 igocene age volcanic rocks of the San Juan Mountains dip into the Valley where they become interbedded with the valley fill deposits. In the subsurface the valley is broken by two horst blocks. At the southern end of the Valley, near the New Mexico border, as a result of block faulting 01 igocene volcanic rocks have been brought to the surface, forming the San Luis Hills (Fig. 2). Extending north form this structure is a easterly tilted, deeply buried horst, named the Alamosa Horst, which is composed of Precambrian age rocks (Tweto, oral communication, 1982; Zeisloft and Mackelprang, in prep.) (Fig. 2). A geothermal well drilled in the City of Alamosa in 1 ate 1981 encountered the Alamosa Horst at a depth in excess of $5,000 \mathrm{ft}(1.52 \mathrm{~km}$ ) (Zeisloft and Mackelprang, in prep.). On either side of the Alamosa Horst are two deep basins, the Baca Graben on the east and the Monte Vista Graben on the west (Fig. 2). It is estimated that the Baca Graben is approx. 19,000 $\mathrm{ft}(5.8 \mathrm{~km})$ deep and the Monte Vista Graben over $10,000 \mathrm{ft}(3.05 \mathrm{~km})$ deep.

Overlying the Precambrian basement rocks is a thick sequence of Tertiary age valley fill sediments and volcanic rocks. The absence of Paleozoic and Mesozoic age sediments reflects the fact that throughout much of geologic time most of the San Luis Valley area was a positive feature.

While the Rio Grande Rift as a whole started developing between 32 and $27 \mathrm{~m} . \mathrm{y}$. ago (Late 01 igocene), the Colorado segment started developing about $26-27$ m.y. ago (Early Miocene). At this same time igneous activity associated with the rifting occurred. Igneous rocks contemporaneous with the rifting occur as far northward as the Wyoming border. During the rifting phase, and continuing up to the present the crust sagged allowing broad shallow basins to form in which mafic flows and volcanic ash beds were interbedded with alluvial deposits which were later broken by faulting. It is beyond the scope of this paper to present a description of all the various rock units found in the western San Luis valley. Table 1 is a summary description of the various rock units. For a more complete description the reader is refered to papers by Burroughs (1981), Lipman (1968 and 1978), Lipman and Mehnert (1975), and Mertzman (1971). 
TABLE 1. STRATIGRAPHIC SECTION, WESTERN SAN LUIS VALLEY (From Lipman, 1976)

\begin{tabular}{|c|c|c|c|c|}
\hline SYSTEM & SERIES & FORMATION & $\begin{array}{l}\text { THICKNESS } \\
\mathrm{ft}(\mathrm{m})\end{array}$ & DESCRIPTION \\
\hline & & Surficial & & Deposits \\
\hline \multirow[t]{5}{*}{ Quaternary } & Holocene & Alluvium & variable & $\begin{array}{l}\text { Silt, sand, gravel, } \\
\text { peat in valley bottoms }\end{array}$ \\
\hline & Holocene & Colluvium & $"$ & \multirow{4}{*}{$\begin{array}{l}\text { Poorly sorted slope } \\
\text { material. } \\
\text { Angular rock fragments } \\
\text { poorly sorted. } \\
\text { Poor sorted rock } \\
\text { debris. } \\
\text { Well sorted sand and } \\
\text { gravel, rounded } \\
\text { boulders. } \\
\text { Poorly sorted silt and } \\
\text { boulder. }\end{array}$} \\
\hline & & Talus dep. & & \\
\hline & Pleistocene & $\begin{array}{l}\text { Landslide } \\
\text { dep. } \\
\text { Glacial } \\
\text { outwash }\end{array}$ & " & \\
\hline & & Alluvial fan & $"$ & \\
\hline
\end{tabular}

REGIONAL LAVAS AND RELATED ROCKS

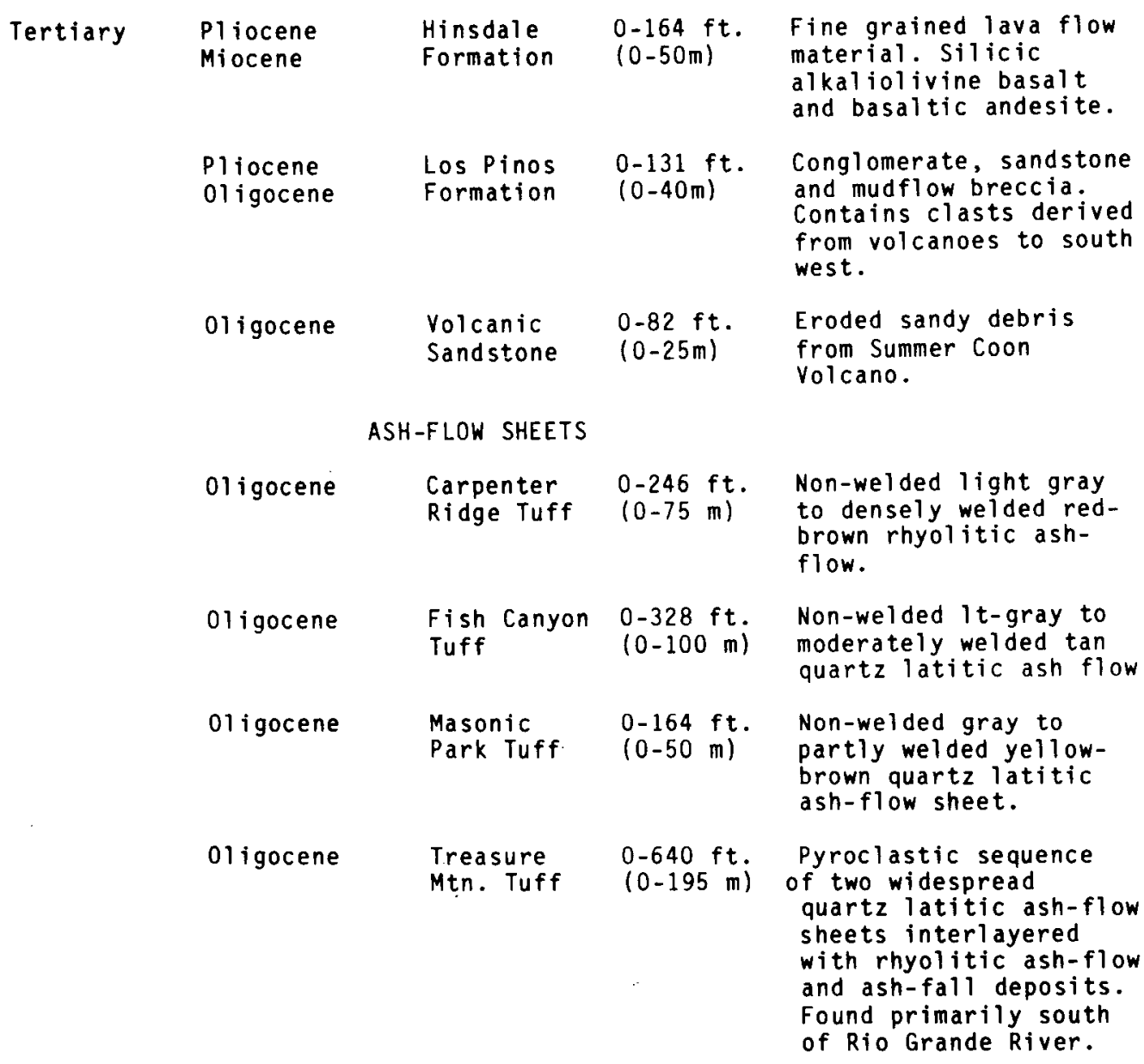

EARLY INTERMEDIATE COMPOSITION ROCK

\begin{tabular}{|c|c|c|c|}
\hline 01 igocene & $\begin{array}{l}\text { Conejos } \\
\text { Formation }\end{array}$ & $\begin{array}{l}0-1.01 \mathrm{mi}) \\
(0-1.64 \\
\mathrm{km})\end{array}$ & $\begin{array}{l}\text { Lava flows and flow } \\
\text { breccias of andesite, } \\
\text { rhyodacite, and quart } \\
\text { latite. Beded. } \\
\text { conglomerate, sandsto } \\
\text { and mudflows. }\end{array}$ \\
\hline 01 igocene & $\begin{array}{l}\text { Flows and } \\
\text { dikes }\end{array}$ & $\begin{array}{l}0-1.11 \mathrm{mi} \\
(0-1.8 \mathrm{~km})\end{array}$ & $\begin{array}{l}\text { Rhyodacite, Quartz } \\
\text { latite, Porphyritic } \\
\text { rhyolite, rhyolite, } \\
\text { and andesite. }\end{array}$ \\
\hline
\end{tabular}


Shaw Warm Springs are located approximately $5 \mathrm{mi}(8.05 \mathrm{Km})$ southeast of, and well down on the southeast flank of the Summer Coon volcanic center (Lipman, 1976). Bedrock of the region consists of rocks ejected from the Summer coon Volcano and other volcanoes located to the west (Fig. 5). Most of these extrusive rocks are predominantly ash flow sheets of Early 01 igocene age called the Masonic Park Tuff, Fish Canyon Tuff and the Carpenter Ridge Tuff (Fig. 5). These units dip eastward into the Valley where they become interbedded with the thick sequence of relatively unconsolidated valley fill material. Intruding these and other rock units are a large number of dikes of varying composition that expand radially from the volcanic complex. Overlying the volcanic rocks are poorly sorted surficial and alluvial deposits ranging from silts to boulders, of Pleistocene and Holocene age.

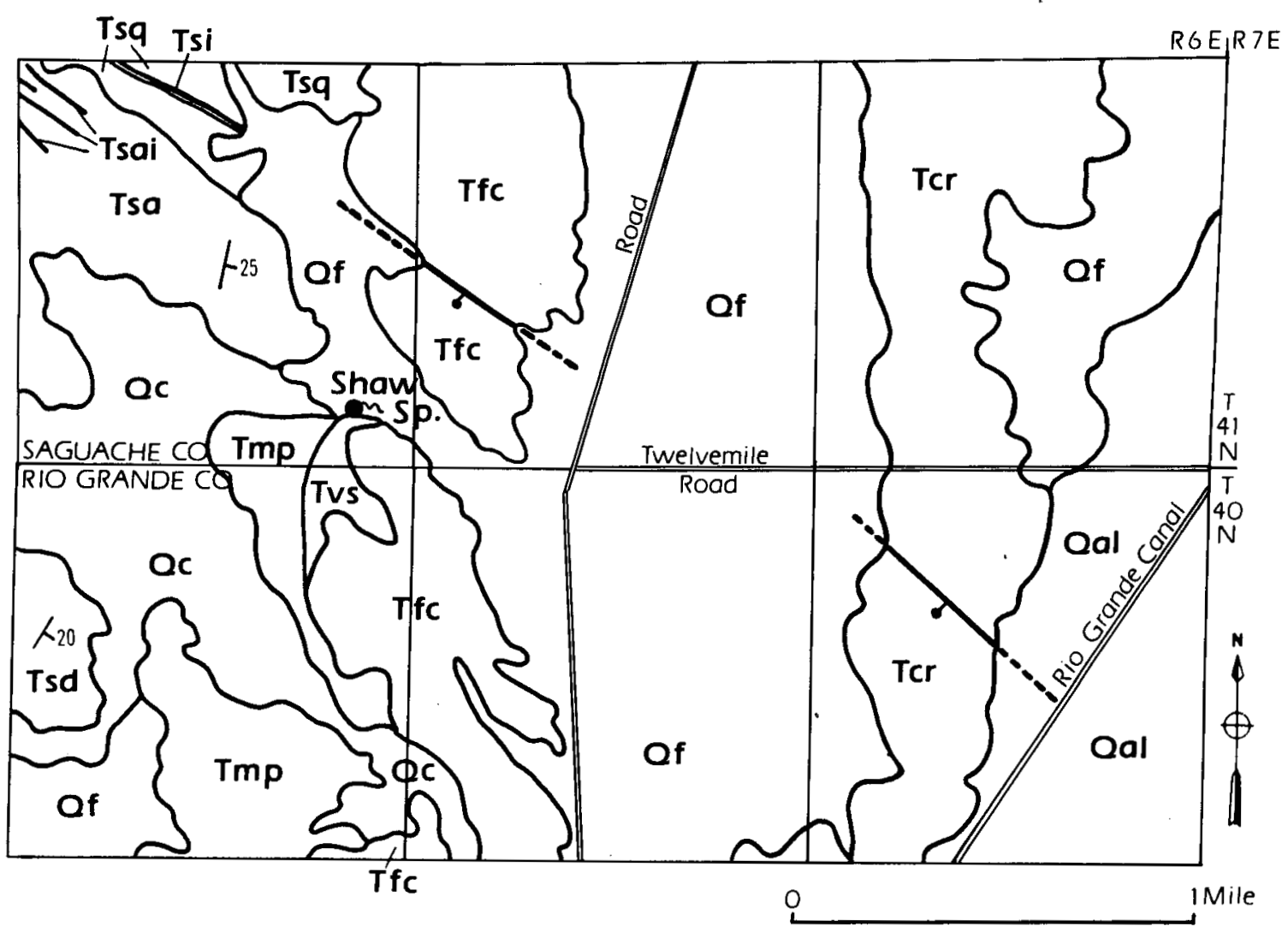

\section{EXPLANATION}

Oal Quaternary alluvium

Oc Quaternary colluvium

Of Quaternary alluvialfan deposits

Tvs Tertiary volcanic sandstone

Tfc Tertiary Fish Canyon Tuff

Tmp Tertiary Masonic Park

Tsq Tertiary quartz latite
Tsa Tertiary andesite

Tsd Tertiary rhyodacite

Tsi Tertiary intermediate composition dike

Tsai Tertiary andesite dike

- Geologic contact

$\perp$ Fault; dashed where inferred, balt on

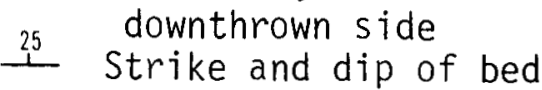

Figure 5. Regional geologic map (adopted from Lipman, 1976) 


\section{HYDROGEOLOGY OF THE WESTERN SAN LUIS VALLEY}

Due to its geologic character the San Luis Valley contains large quantities of non-thermal ground waters at relatively shallow depths. Over the years a successful agricultural industry has developed based on the use of these ground-water supplies. The hydrogeological investigations conducted in the Valley by Emery and others (1971 and 1973), Huntley (1975), and Powel1 (1958) dealt primarily with the nonthermal water of the valley, which are used for irrigation purposes, and not the thermal resources. For the most part these waters have no relationship to the thermal waters and therefore will not be discussed in any detail here.

Emery and others (1972) reported the existence of thermal water wells north and east of Shaws Warm Spring in the more central parts of the Valley. These waters were coming from wells having reported depths ranging from $354 \mathrm{ft}$ ( 108 $\mathrm{m})$ to $4,200 \mathrm{ft}(1.28 \mathrm{~km})$. From an examination of the literature plus field investigations, it appears that the only hydrothermal area along the western side of the San Luis Valley the Shaw Warm Springs area. While no in-depth papers have been published on the hydrothermal conditions of the western San Luis Valley, a number of papers have been published pertaining to the thermal conditions of the Shaw Warm Springs area. These papers have been authored by: Barrett and Pearl (1976 and 1978), Berry and others (1980); George and others (1920); Lewis, (1966); Mallory and Barnett (1973); Pearl (1972 and 1979); and Waring (1965).

George and others (1920) made the first comprehensive appraisal of the thermal waters of colorado and the medicinal values associated with them. Those interested in the historic treatment of this subject will find this report of immense value. In addition to reporting the chemical composition of the thermal waters, George and others (1920) listed such physical parameters as temperature, location, radioactivity, and location of the spring. In 1978 Barrett and Pearl, following up on the work of George and others (1920), reevaluated the thermal waters of of Colorado. They (Barrett and Pearl, 1978) relocated the thermal water sources, measured their temperature, $\mathrm{pH}$, and other field parameters, and had a complete modern chemical analysis of the waters made. In addition they tried through the use of geochemical geothermometer models to estimate the subsurface reservoir temperatures. In 1979 Pearl carried this analysis one step futher and presented estimates of the size and extent of the thermal area (Table 2).

Barrett and Pearl (1978) and Pearl (1979) stated that they believed recharge for Shaw Warm Springs was probably occurring in the higher ground to the west. They felt that as the ground waters moved downdip through permeable interflow units the waters became heated due to residual heat from the Tertiary volcanic activity of the area. 
Table 2. Resource analysis of Shaw Warm Springs

(From Barrett and Pearl, 1978 and Pearl, 1979).

Geothermometer temperature estimates:

Mixing Model (amorphous silica)...... $81^{\circ} \mathrm{F}\left(27^{\circ} \mathrm{C}\right)$

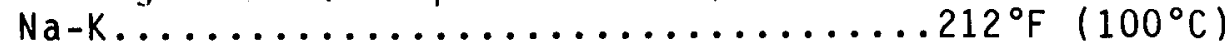

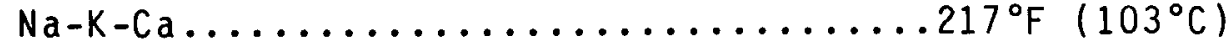

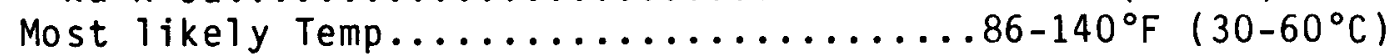

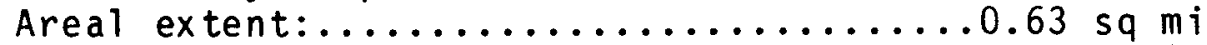



(1 $Q$ of heat energy $=1,000,000,000,000,000$. B.T.U.'s)

Barrett and Pearl (1978) noted that the above reservoir temperature estimates should be used with caution because most the assumptions inherent in their use are violated. Therefore after a review of all the data they stated that the most 1 ikely reservoir temperature for this area is between 86 and $140^{\circ} \mathrm{F}(30$ and $\left.60^{\circ} \mathrm{C}\right)$. 
During the course of this investigation, in an attempt to map the subsurface geological conditions of the western San Luis Valley, the following geophysical surveys were carried out: seismic; electrical resistivity; telluric; Audio-magnetotelluric (AMT); and time-domain electromagnetic soundings by either the Colorado Geological Survey, U.S. Geological Survey, the Colorado School of Mines summer field camp, or by private companies. Most of these investigations were primarily designed to map the geological conditions controlling Shaw Warm Springs, and to that end they were partially successful.

\section{Electrical Resistivity Surveys}

Dipole-Dipole Resistivity Surveys:

In the immediate vicinity of Shaw Warm Springs the Colorado Geological Survey ran 6 dipole-dipole electrical resistivity traverses totalling 20,100 ft $(6.1$ $\mathrm{km})(\mathrm{Fig} .6)$ to determine the boundaries of low resistivity zones. These zones are one of the primary indicators of geothermal systems. A complete description of all the various factors which might affect electrical resistivity measurements are presented in Appendix C. A complete description of the equipment used in these surveys is presented in Appendix $D$.

One of the more common methods of portraying and interperating electrical resistivity data is through the use of pseudosections. These essentially are cross sections drawn for each traverse line showing the measured resistivity values. In the interperation of these sections one must be aware that lateral variations in the subsurface geological conditions may influence the resistivity measurements. Figures 7 to 12 are pseudosections for the various dipole-dipole resistivity traverses. Due to geological conditions and equipment limitations it was only possible to acquire information on the subsurface conditions to a depth of 300 to $400 \mathrm{ft}(91.4$ to $122 \mathrm{~m})$. Another method, which was not used, to interperate electrical resistivity geophysical data are detailed computer models. These models would give a more accurate description of the individual faults.

These surveys were successful in helping to delineate the geological controls of Shaw Warm Springs. A northwest trending fault passing through Shaws Warm Spring was delineated. Unfortunately no data were acquired along the traverse line bisecting the mapped fault approximately $0.5 \mathrm{mi}(0.8 \mathrm{~km})$ to the north.

Schlumberger Depth Soundings:

In addition to the dipole-dipole surveys, three Schlumberger depth sounding surveys were made. Data from 300,500 , and $900 \mathrm{ft}(91,152$, and $274 \mathrm{~m})$ depths were used to prepare subsurface contour maps of the Shaw Warm Springs area delineating the areal extent of the thermal reservoir (Figs $13,14,15$ ). As is noted, the reservoir appears to be located north of Shaw Warm Springs and is bounded by the mapped fault located approx. $0.5 \mathrm{mi}(805 \mathrm{~m})$ north of Shaw Warm springs, in the next valley. 


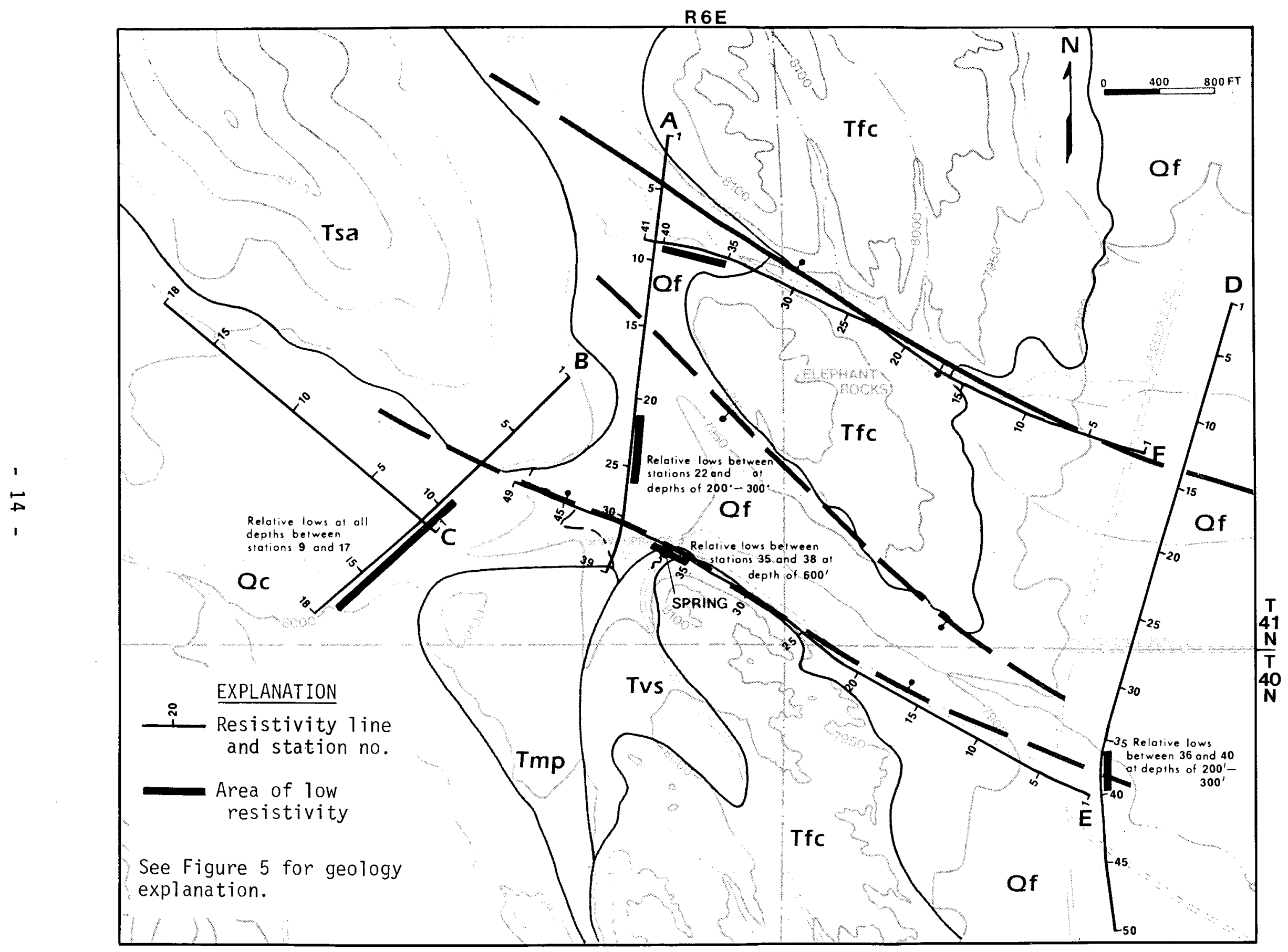

Figure 6. Location of dipole-dipole resistvity survey, western San Luis Valley, Colorado. 
South

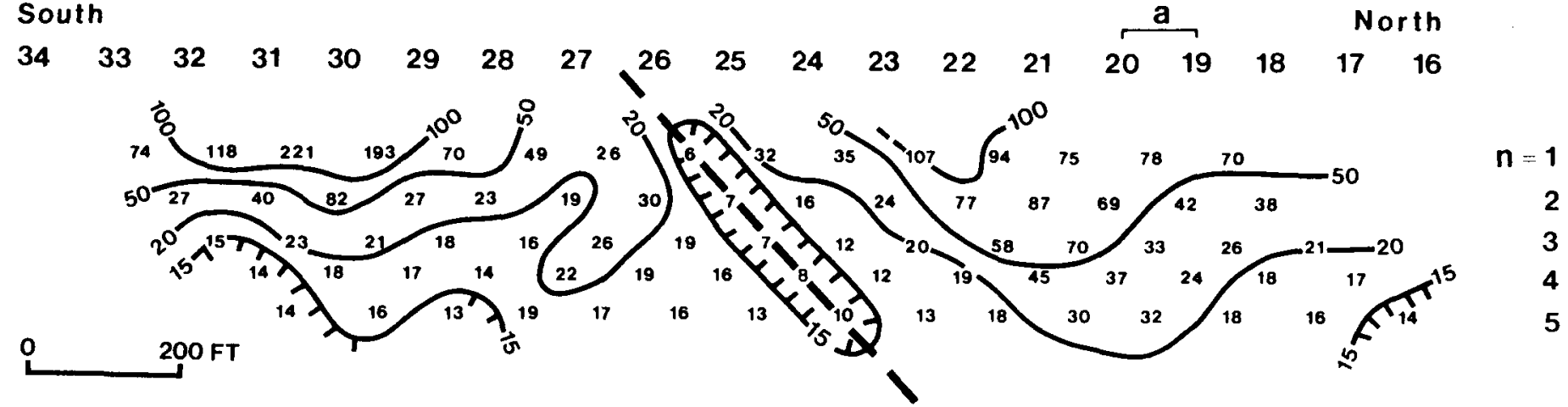

A low resistivity zone was mapped between stations 23 to 27 approximately 400 $\mathrm{ft}$ northwest of the warm springs area. The resistivity values increase north and south of this area. At the surface to the south, the values increase to $221 \mathrm{ohm}$-meters, however, at depth $(n=5)$ the values decrease to approximately 15 ohm-meters. These low values may be attributed to either water saturated alluvium or possibly a fault downthrown to the north. Generally, the values along this line demonstrate a higher resistive surface rock which may be due to a buried stream channel or faulting (data from Stations 1-16 were not obtained).

LENGTH: $1800 \mathrm{ft} \mid 549 \mathrm{~m}$ | SEPARATION: $\mathbf{n}$ Value DATE : $6 / 30 / 80$

TYPE: Dipole - Dipole SPREAD: $a=100 \mathrm{ft}$ RESISTIVITY: In ohm meters POSSIBLE FAULT:

Figure 7. Dipole-dipole pseudosection line A.



A low resistivity zone was mapped between stations 9 to 18 . This zone which may be a fault zone correlates with the low resistivity fault zone mapped on line A. An additional deep-seated low was mapped between stations 4 and 6 .
LENGTH: $1800 \mathrm{ft} \mid 549 \mathrm{~m}$ | SEPARATION: $n$ Value DATE : $6 / 30 / 80$

TYPE: Dipole-Dipole SPREAD: $a=100 \mathrm{ft}$ RESISTIVITY: In ohm meters POSSIBLE FAULT:

Figure 8. Dipole-dipole pseudosection line $B$. 

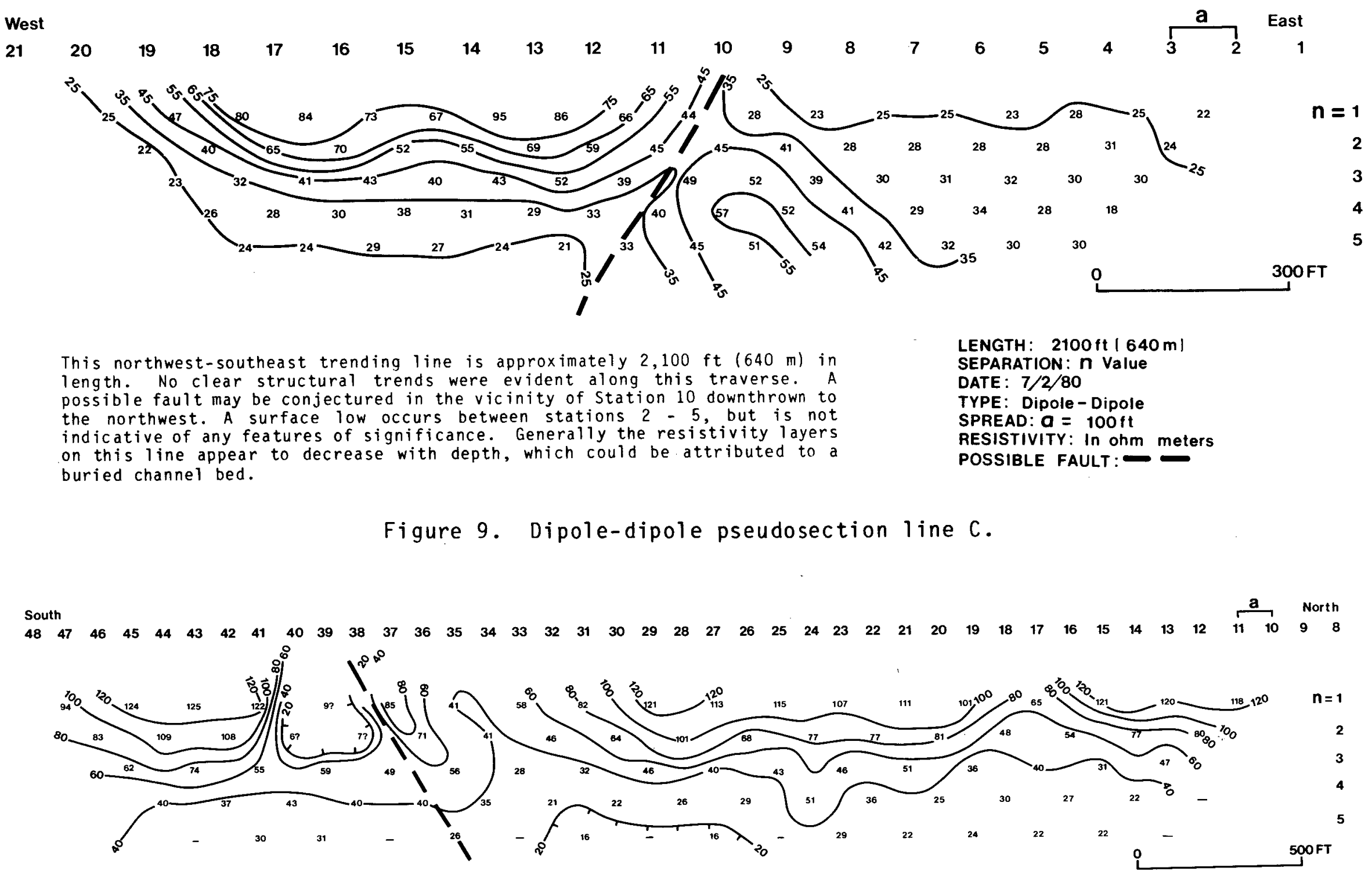

This line, parallel to the north - south county road, was the longest traverse conducted $(5,000 \mathrm{ft}(1.52 \mathrm{~km}))$ during the course of this investigation. A very pronounced low resistivity zone was mapped in the vicinity of stations 37 through 40 with values as low as $5 \mathrm{ohm}$-meters. This low zone, however, does not persist with depth, and the fault depicted is very questionable. The unnamed creek that flows by Shaw Warm Springs could be controlled by this fault. The surface layers reflect higher resistivity values than the deeper

LENGTH: $5000 \mathrm{ft} 11524 \mathrm{~m} \mathrm{r}$

SEPARATION: $n$ Value

DATE : $7 / 8 / 80$

TYPE: Dipole-Dipole

SPREAD: $a=100 \mathrm{ft}$

RESISTIVITY: In ohm meters

POSSIBLE FAULT:

layers.

Figure 10. Dipole-dipole pseudosection line D. 

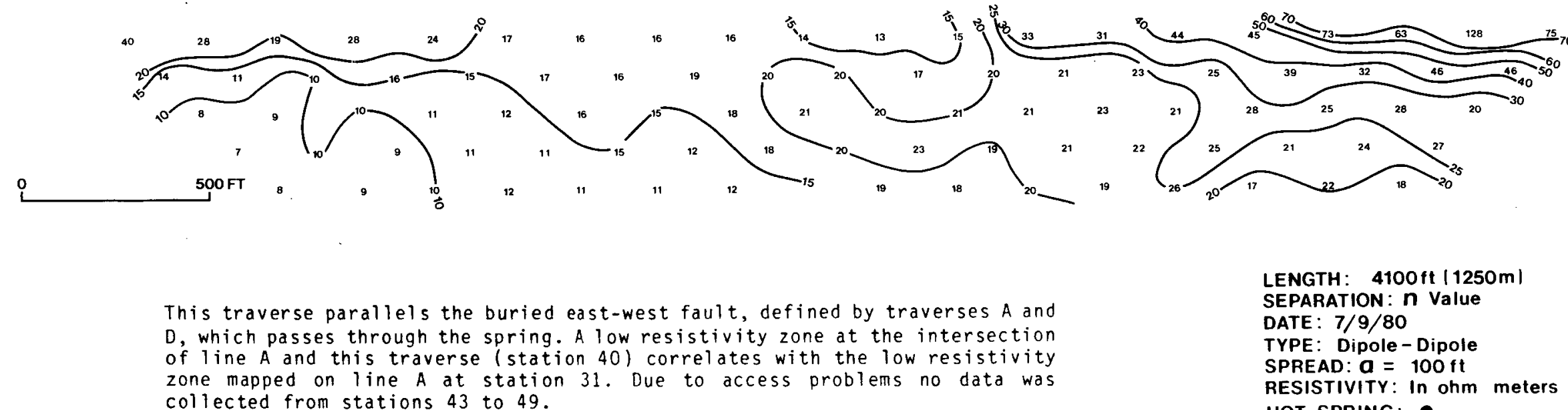

$\mathbf{n}=1$ line $A$ and this traverse (station 40 ) correlates with the low resistivity collected from stations 43 to 49 .

\section{LENGTH: $4100 \mathrm{ft}|1250 \mathrm{~m}|$ \\ SEPARATION: $n$ Value \\ DATE: $7 / 9 / 80$ \\ TYPE: Dipole-Dipole \\ SPREAD: $a=100 \mathrm{ft}$ \\ RESISTIVITY: In ohm meters \\ HOT SPRING:}

Figure 11. Dipole-dipole pseudosection line E.

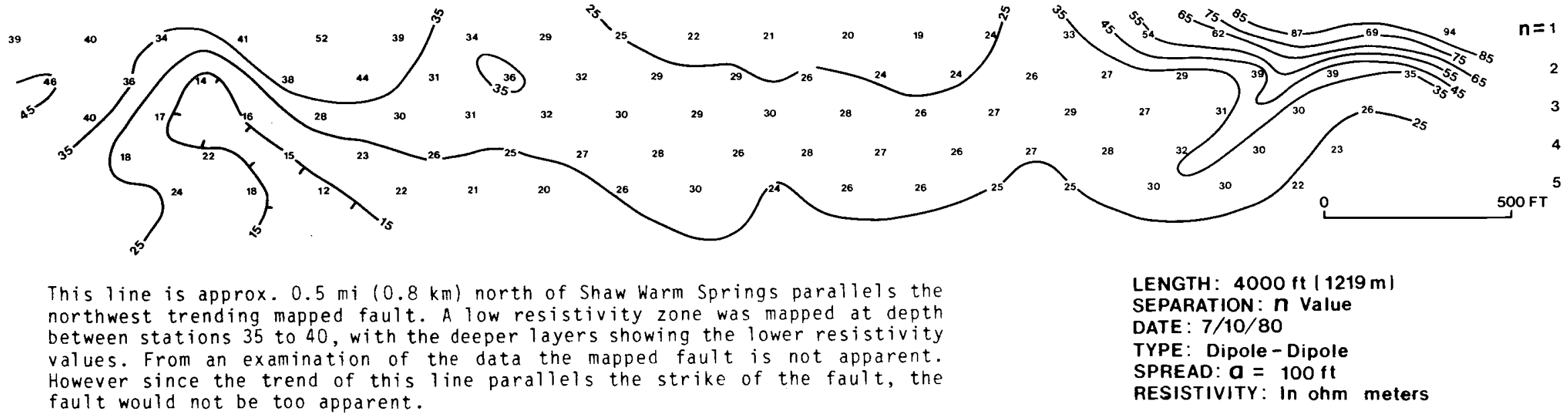

Figure 12. Dipole-dipole pseudosection line F. 


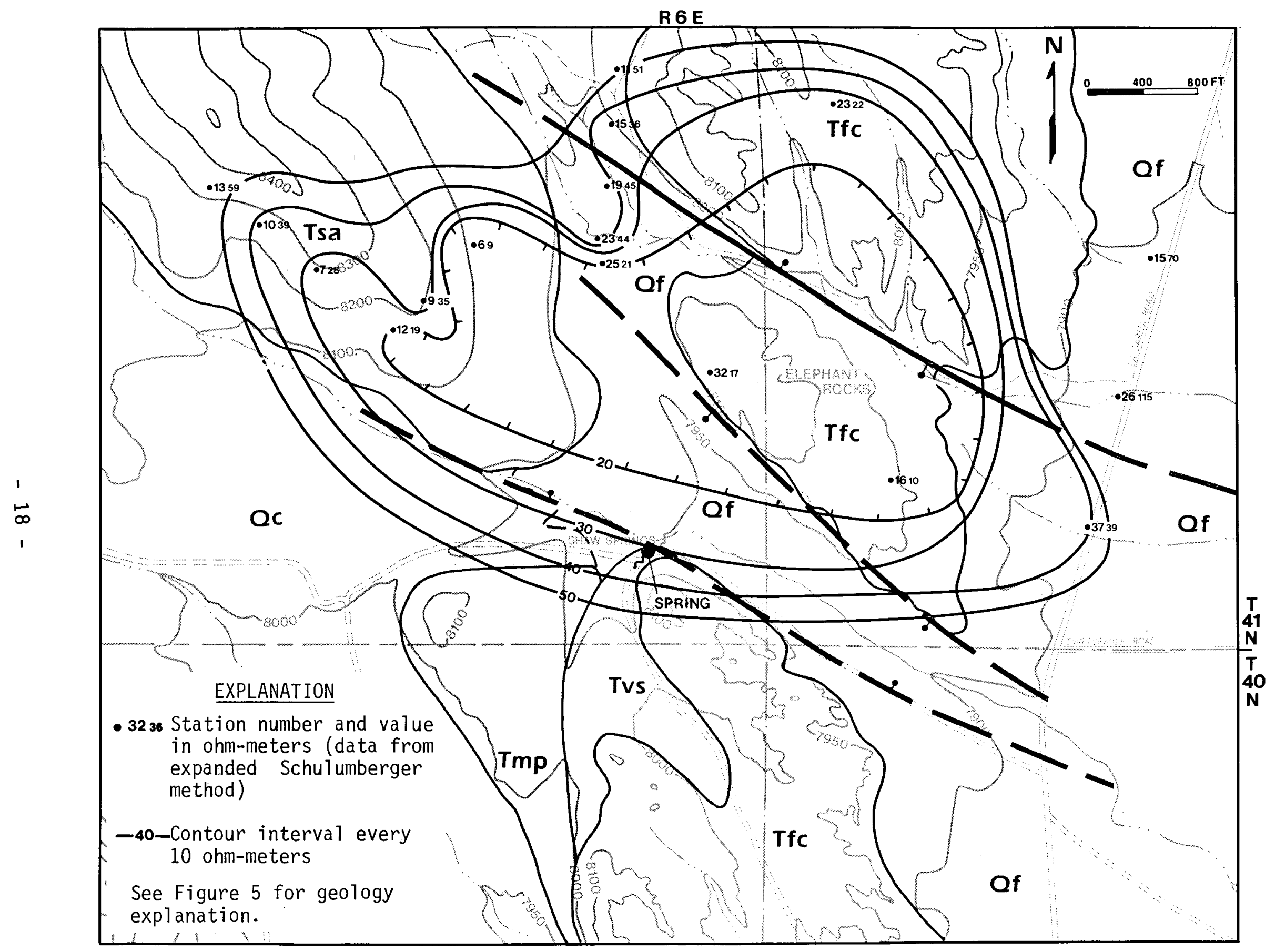

Figure 13. Schlumberger depth sounding, $300 \mathrm{ft}$. depth 


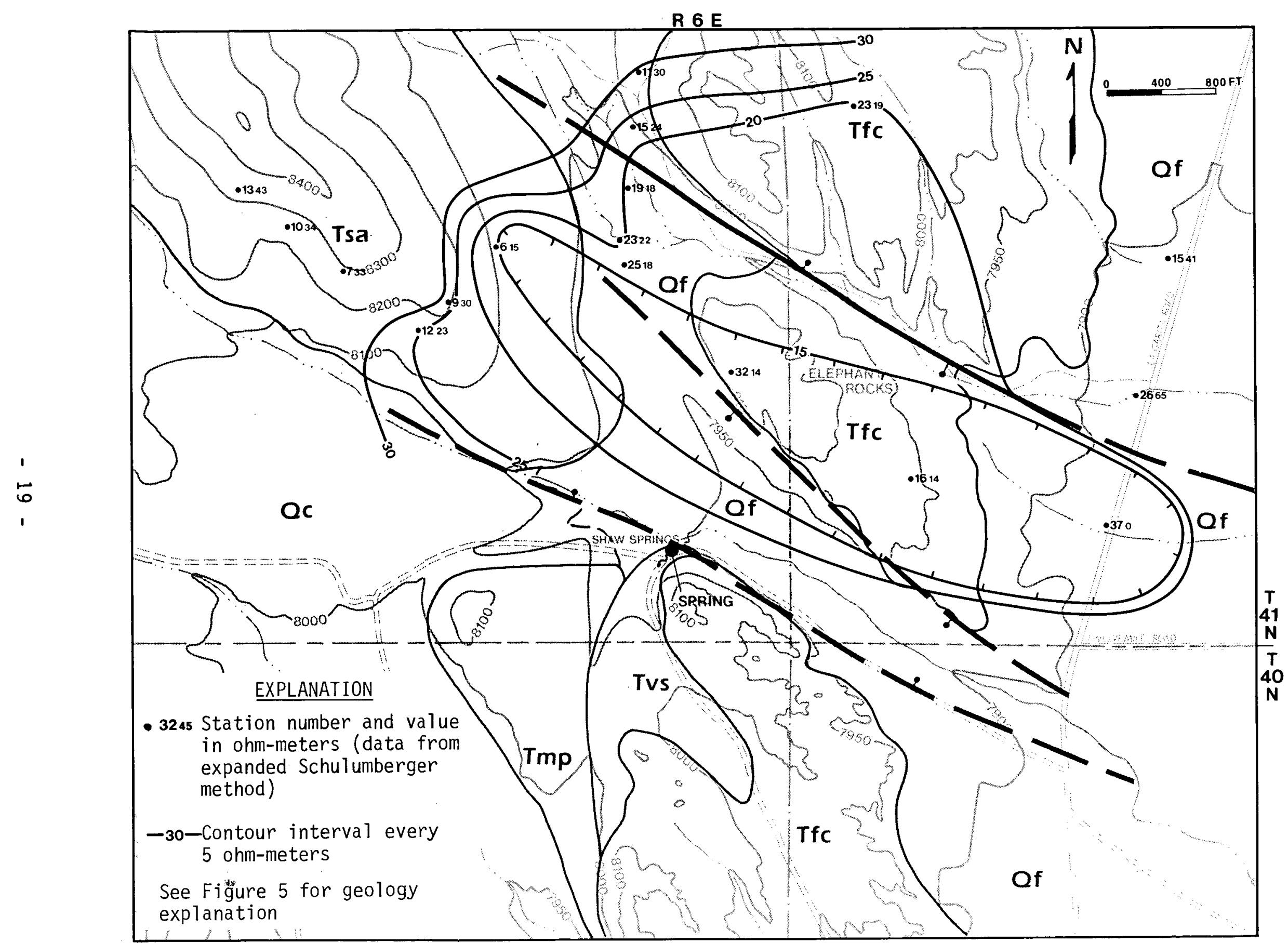

Figure 14. Schlumberger depth sounding, $500 \mathrm{ft}$. depth 




Figure 15. Schlumberger depth sounding, $900 \mathrm{ft}$. depth. 


\section{Audio-magnetotelluric and Telluric Surveys}

During the summer of 1980 personnel from the U.S. Geological Survey ran Audio-magnetotellurics (AMT) and telluric surveys in the Shaw Warm Springs region (Christopherson and others, 1981). The following is a summary of their findings and conclusions.

Two northeast trending telluric profiles were made in the Shaw Warm Springs area using 250 meter dipoles (Fig. 16). These profiles delineated three faults in the region, one of which was known and two previously unmapped faults. Evidence was gathered to extend the fault that Lipman (1976) had mapped approximately $.5 \mathrm{mi}(.8 \mathrm{~km})$ north of Shaw Warm Springs to the west and east. The two previously unmapped faults were in the Shaw Warm Springs valley south of the Elephant Rocks. One of these faults is just south of the Elephant Rocks and the other is in the vicinity of the warm springs that follows the drainage of Shaw Warm Springs.

The AMT surveys showed that there is a lack of warm waters to at least a depth of $1640 \mathrm{ft}(500 \mathrm{~m})$ although there may be some leakage into the valley fill material east of Shaw Warm Springs. The concluded that no significant reservoir is apparent, other that what may be present in the valley fill.

\section{Geophysical Surveys Conducted by the Colorado School of Mines}

During the summer of 1980 the Colorado School of Mines (C.S.M.), Department of Geophysics, conducted seismic reflection and refraction and time-domain electromagnetic sounding as part of its summer field camp in the western San Luis Valley. Bond (1981) evaluated all of the geophysical surveys conducted by C.S.M. and others in the western San Luis Valley area. Bond's studies showed that a low resistivity zone is present in the immediate vicinity north of Shaw Warm Springs, which may be related to the thermal water emerging from the mapped faults in the area.

\section{Seismic Reflection Surveys:}

Geophysics Fund Inc., under contract to the Colorado Geological Survey, attempted seismic reflection surveys along the western side of the San Luis valley. Due to unfavorable geological conditions, namely volcanic flows, the reflective data acquired was poor. James K. Applegate (1981), project leader, noted that it is possible to analyze this problem by looking at seismic data acquired in other portions of the San Luis Valley and from other studies in similar geological provinces and contrasting them to the Shaw Warm Springs data.

Applegate (1981), noted that much better quality seismic data has been acquired on the east side of the San Luis Valley where there is a thicker section of sediments. He postulated that on the west side the thicker volcanic rock sequence, which occurs closer to the surface than on the east side, may act as a scatterer and reflector of the seismic energy. To over come this problem Applegate suggested that maybe a different set of seismic parameters than those used might give useful seismic data on the western side of the valley. 


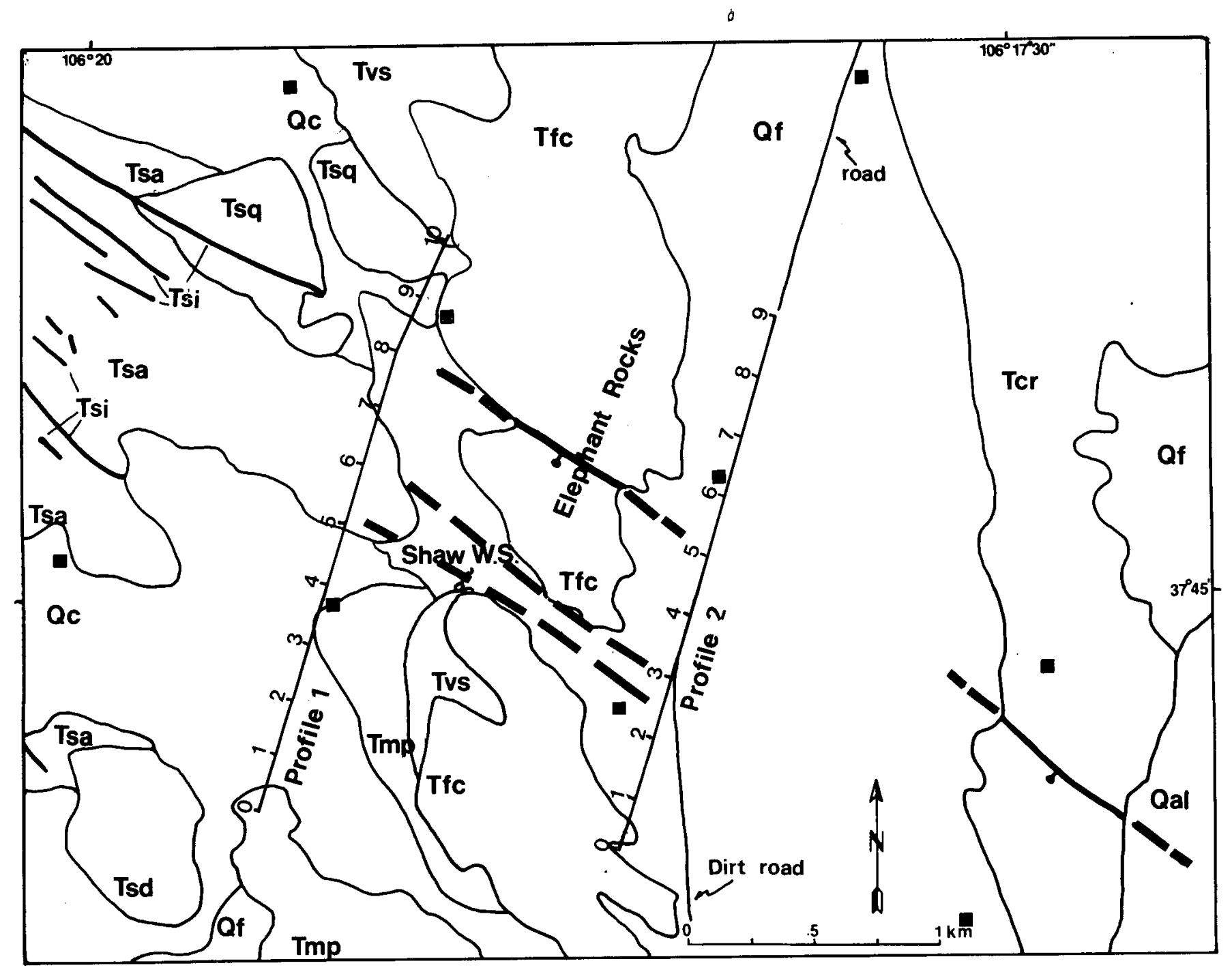

EXPLANATION



Tsd Tertiary rhyodactite

Tsq Tertiary quartz

Tsa Tertiary andesite

Tsi Tertiary dikes

- AMT stations

Fault; dashed where
inferred, ball on
downthrown side

Figure 16. Telluric profile location map and generalized geology of Shaw Springs, Colorado (adopted from Christopherson and others, 1981). 
Applegate (1981), noted that successful seismic surveys have been conducted in other interlayered volcanic rock areas, such as the Snake and Raft River Plains of Idaho and the Nevada Test Site. These surveys were conducted utilizing high resolution seismic methods with very close geophone spacings using "Vibroseis" equipment ("Vibroseis" is a registered trademark of Continental 0il Company).

In summary, Applegate (1981) stated that in light of the geological conditions of the area and equipment limitations, it would appear, that no matter what methods are used, that it would be difficult to acquire quality seismic data on the western flank of the San Luis Valley. It is possible that there are "windows" where one could see through the shallow volcanics. However, it is al so quite possible that these windows are very limited in extent and that it would be very expensive and difficult to locate them.

Applegate (1981) stated that it appears unlikely that, without extensive work, it will be impossible to acquire quality seismic data on the western flank of the valley and, in particular, in the Shaw Warm Springs area. How far one has to go to the east before the data quality improves significantly is an unknown factor which can be determined only by expanded field effort.

Time-Domain Electromagnetic Sounding Surveys:

Students at the Colo. School of Mines geophysical summer camp ran two time-domain electromagnetic sounding. (TDEM) surveys north and east of Shaws Warm Springs (Fig. 17). TDEM is an electrical prospecting technique that provides information about the electrical properties of rocks to a depth of several kilometers. Bond (1981) presents a complete description of the theory and the field techniques employed by this method.

Based on TDEM soundings conducted in the Shaw Warm Springs area Bond (1981), drew an east-west and a north-south section (Figs 18 and 19). According to Bond (1981) these two sections, which represent a complete coverage of the Shaw Warm Springs area, show a zone to a depth of at least $3,281 \mathrm{ft}(1000 \mathrm{~m})$ of saturated volcanic flows, tuffs and alterations. 
R6E,R7E

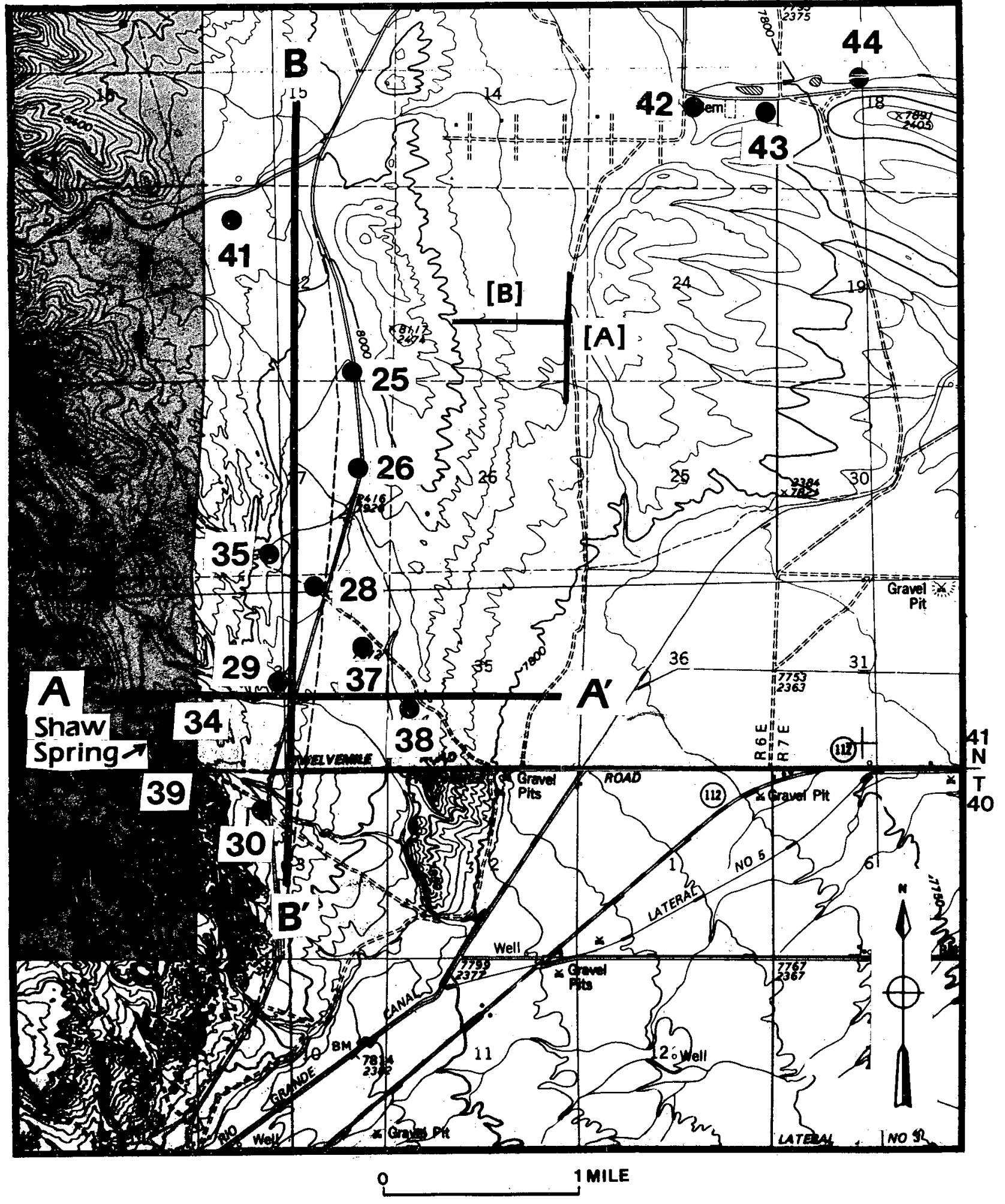

Figure 17. TDEM receiver and profile locations map. Sources (A) and (B). (Adopted from Bond, 1981.) 

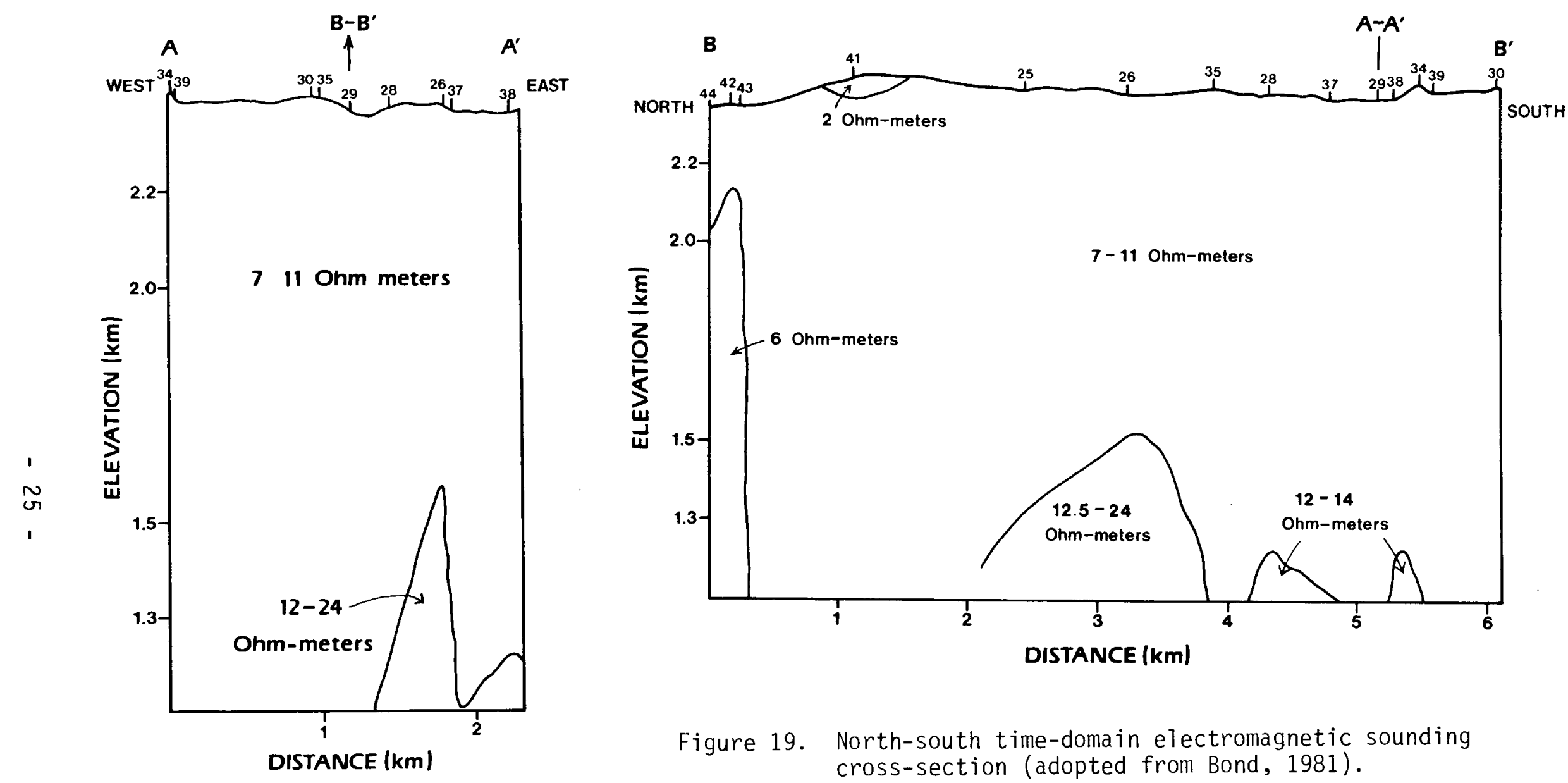

Figure 18. East-west time-domain electromagnetic sounding cross-section (adopted from Bond, 1981).

Figure 19. North-south time-domain electromagnetic sounding cross-section (adopted from Bond, 1981). 


\section{SOIL MERCURY SURVEYS}

\section{Introduction}

The majority of exploration methods used in geothermal exploration are the more common ones such as geology, geophysics, and hydrogeological mapping; however, new methods are beginning to be used. One of these, soil mercury surveys, has proven successful in a number of instances. For example, Capuano and Bamford (1978), Cox and Cuff (1980), K1usman and others, (1977), K1 usman and Landress, (1979), and Matlick and Buseck (1976) have demonstrated the use of soil mercury surveying as a geothermal exploration tool. Both Matlick and Buseck (1976), and more recently Cox and Cuff (1980), have used soil mercury surveys on a regional scale. On a detailed scale, soil mercury surveys can delineate faults or permeable zones in geothermal areas. The association of mercury with geothermal deposits has been shown by White (1967). Matlick and Buseck (1976) stated that areas with known thermal activity, such as: Geysers, California; Wairakei, New Zealand; Geyser, Iceland; Larderello, Italy; and Kamchatka, Russia all contain mercury deposits.

Matlick and Buseck (1976), in presenting the geochemical theory behind the associations of mercury with geothermal deposits, noted that mercury has great volatility, and that the elevated temperatures of most geothermal systems tends to cause the element to migrate upward and away from the geothermal reservoir. In addition, they noted the work of White (1967) and White and others (1970), showed that relatively high concentrations of mercury are found in thermal waters. Matlick and Buseck (1976) pointed out that soils in thermal areas should be enriched in mercury, with the mercury being trapped on the surfaces of clays and organic and organometallic compounds.

Matlick and Buseck (1976) presented four case studies where they used soil mercury concentrations as an exploration tool. Three of the four areas tested, Long Valley, California, Summer Lake and Klamath Falls, Oregon indicated positive anomalies. At the fourth area, East Mesa in the Imperial Valley of California, no anomaly was observed, although isolated elevated values were recorded.

Klusman and others (1977) evaluated the soil mercury concentration in the Glenwood Springs geothermal area. Their sampling and analysis procedures differ from Matlick and Buseck (1976) in that they first decomposed the soils using hydrogen peroxide and sulfuric acid; then a flameless atomic absorption procedure was used to determine the concentration of mercury. Their survey indicated anomalous zones at Glenwood Springs.

Soil Mercury surveys were run by Capuano and Bamford (1978) at the Roosevelt Hot Springs known Geothermal Resource Area, Utah. They analyzed the soil samples with a Jerome Instrument Corp. gold film mercury detector. The results of their investigation showed that mercury surveys can be useful for identifying and mapping faults and other structures controlling the flow of thermal waters and for delineating areas overlying near-surface thermal activity.

\section{SOIL MERCURY SURVEY IN THE SHAW WARM SPRINGS AREA}

Employing sampling methods set forth by Capuano and Bamford (1978), 143 soil samples were collected during the summer of 1979 at $100 \mathrm{ft}(30.48 \mathrm{~m})$ intervals in the Shaw Warm Springs area (Fig. 20). The lines were located to cross any 


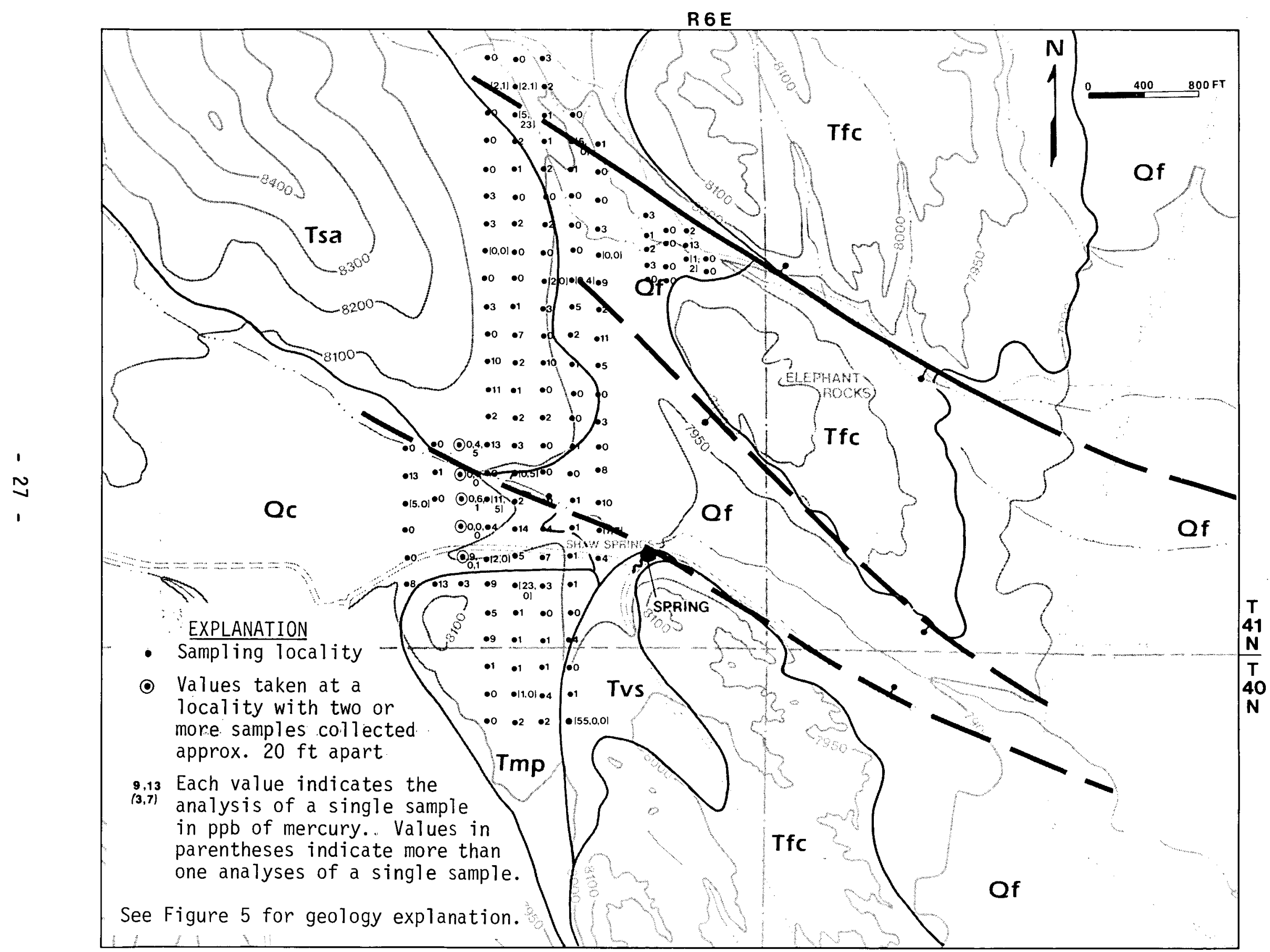

Figure 20. Location, soil mercury lines, Shaw Warm Springs. 
possible controlling faults. Analytical results ranged from a low of 0 ppb to a high of $55 \mathrm{ppb}$. A complete description of the equipment and methodology

- employed by the Colorado Geological Survey for this program at Shaw Warm Springs are presented in Appendix $F$.

\section{Soil Description}

Soil development along the three lines is very thin or nonexistent. For the sample localities located on the Tertiary andesite bedrock, samples were collected just above the bedrock usually at a depth of less than 7 in $(17.78$ $\mathrm{cm})$. For those samples collected in the Quaternary deposits and in the Tertiary tuffs, sands and gravels were consistently found at sampling depth which varied from $4-7$ in $(10.16-17.78 \mathrm{~cm})$.

\section{Mercury Anomalies}

Sixteen samples were collected about one mile south of Shaw Warm Springs to determine the soil mercury background values. Analysis determined that the mercury contained in these samples ranges from less than $1 \mathrm{ppb}$ to $8 \mathrm{ppb}$. These samples were all taken from Quaternary alluvial fan deposits, and thus are not completely representive of the study area. Analysis of the mercury values in the study areas was not so straightforward because there were so many values less than $1 \mathrm{ppb}$.

To aid in determination of background vs anomalous concentration levels the analytical data was graphically plotted and analyzed (Fig. 21). Based on a subjective interperation of the histogram plot of the analytical data, it was decided that all values above 6 ppb should be considered anomalous.

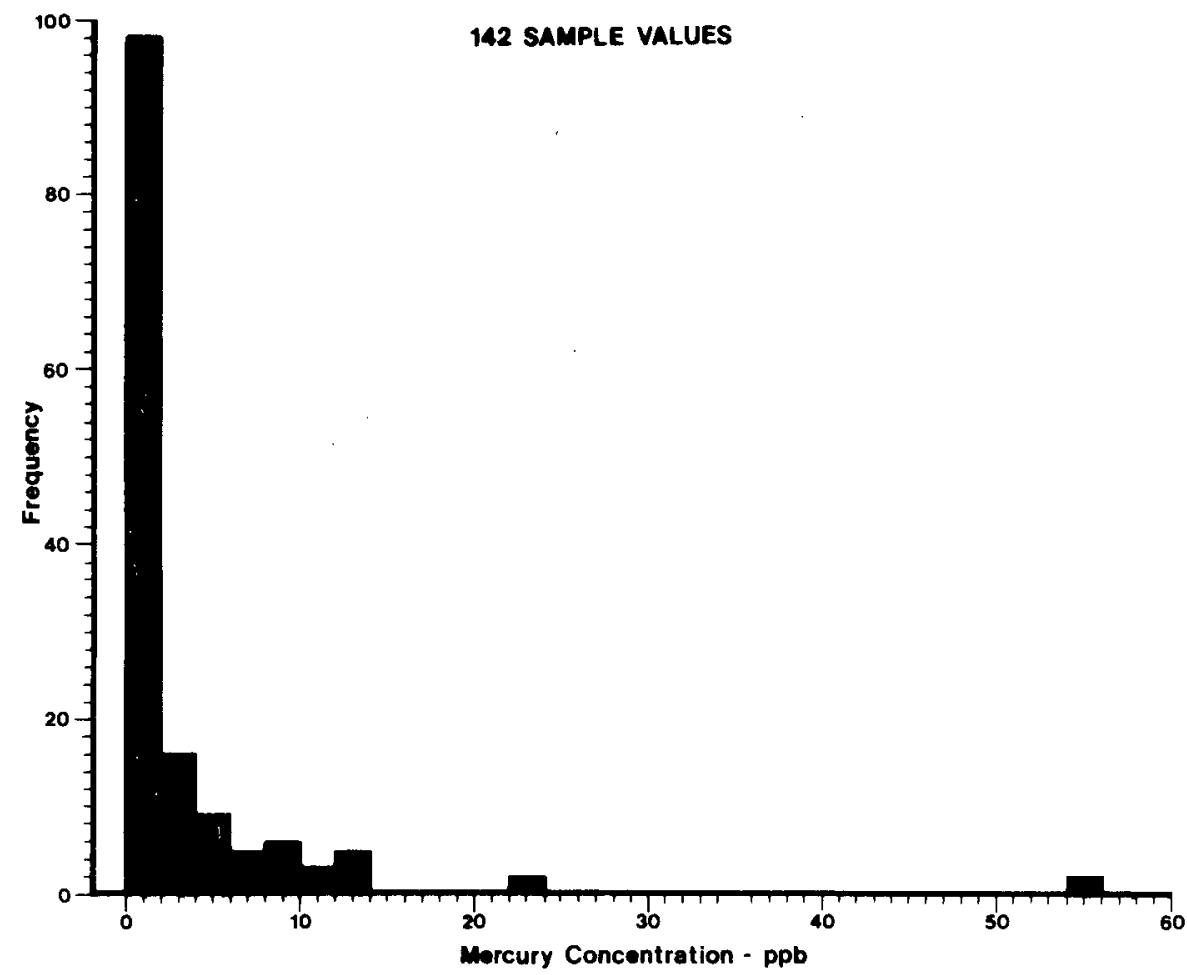

Figure 21. Shaw Warm Springs, Colorado soil mercury histogram 
At numerous sample sites mercury concentrations were measured above the expected background limits ( $F i g .20)$. Upon reanalysis many of these values were determined not to be significant. Cursory observation suggests that variation due to laboratory analysis is contributing a high percentage of the variance between sample localties.

Even though some of the anomalous values upon reanalysis proved to be lower, the presence of several faults is indicated (Fig 20). Prior to the commencement of this study one of these faults was unknown. This fault, which trends in a northwest direction, is located just adjacent to Shaw Warm Springs and is indicated by several high analytical values. Another fault, which had been previously mapped, located in the first valley north of Shaw Warm Springs, is indicated by high analytical values.

One of the problems why more definitive values were not recorded may have been the unfavorable soil media (sand and gravel material) for adsorbing mercury.

Table 3 Analytical mercury values, Shaw Warm Springs area.

$\begin{array}{llllllllll}0 \star & 0 & 0 & 0 & 1 & 1 & 2 & 3 & 5 & 11 \\ 0 \star \star & 0 & 0 & 0 & 1 & 1 & 2 & 3 & 5 & 13 \\ 0 & 0 & 0 & 0 & 1 & 1 & 2 & 3 & 7 & 13 \\ 0 & 0 & 0 & 0 & 1 & 1 & 2 & 3 & 7 & 13 \\ 0 & 0 & 0 & 0 & 1 & 2 & 2 & 3 & 7 & 13 \\ 0 & 0 & 0 & 0 & 1 & 2 & 2 & 3 & 8 & 14 \\ 0 & 0 & 0 & 0 & 1 & 2 & 2 & 4 & 8 & 23 \\ 0 & 0 & 0 & 0 & 1 & 2 & 2 & 4 & 9 & 55 \\ 0 & 0 & 0 & 0 & 1 & 2 & 2 & 4 & 9 & \\ 0 & 0 & 0 & 0 & 1 & 2 & 3 & 4 & 9 & \\ 0 & 0 & 0 & 0 & 1 & 2 & 3 & 5 & 10 & \\ 0 & 0 & 0 & 0 & 1 & 2 & 3 & 5 & 10 & \\ 0 & 0 & 0 & 1 & 1 & 2 & 3 & 5 & 10 & \\ 0 & 0 & 0 & 1 & 1 & 2 & 3 & 5 & 11 & \\ 0 & 0 & 0 & 1 & 1 & 2 & 3 & 5 & 11 & \end{array}$

* Represents first value recorded and no replicated values.

** Zero should be interpreted as less than $1 \mathrm{ppb}$. 


\section{ORIGIN OF THE SHAW WARM SPRINGS THERMAL WATERS}

Due to the lack of any deep water wells or water isotope data in the study area, the authors were limited in their efforts to fully evaluate the thermal conditions of the region and in the preparation of a working model of the thermal conditions. However, based on interpretation of the geologic conditions of the area and the known conditions at other thermal systems of the world, some basic assumptions can be made concerning the origin of the thermal waters of this system.

Thermal waters are of either magmatic or meteoric origin. Magmatic waters are waters driven off from a cooling igneous rock body. Meteoric waters are those waters which have fallen on the surface of the earth in the form of precipitation, then due to natural processes have become part of the ground-water system. Craig (1961) and Craig and others (1956) have demonstrated that most thermal waters are of meteoric origin. To definitely prove that the thermal waters of the study area are of meteoric origin would necessitate sampling and analyzing the waters for various oxygen isotopes, which was not done. There is a remote possibility that the thermal waters of Shaw Warm Springs could be of magmatic origin, however on a world wide basis waters of this origin are very rare and until proven otherwise it will be assumed that the thermal waters of the study area are of meteoric origin.

As is normal, most of the precipitation falling upon the surface of the land in the form of snow or rain runs off and becomes part of the rivers and streams of the area. However, a small part of this precipitation flows into the earth and becomes part of the ground-water regime. As this water circulates downward to depth along the many faults and fractures in an area of above normal geothermal gradients it becomes heated.

One of the problems left unanswered by this investigation is the mechanism by which the ground waters are heated. The several possible means by which the waters could become heated are volcanic rocks, high heat flow, and decay of radioactive minerals. While the San Juan volcanic field is composed of Tertiary age volcanic rocks (Table 2) theoretically these rocks are too old (>20 million years) to be the source of the heat. Another mechanism by which the waters could become heated is by the regional heat-flow of the area. Heat-flow calculations have shown that the San Luis Valley has above normal heat-flow (Edwards and others, 1978, Reiter and others, 1975, and Zacharakis, 1981). The regional heat-flow of the western San Luis Valley ranges from less than 100 $\mathrm{mW} / \mathrm{m} 2$ to over $120 \mathrm{~mW} / \mathrm{m} 2$. This is above the state wide average of approximately $100 \mathrm{~mW} / \mathrm{m} 2$ (Fig. 3). Cordell (1978), in his geophysical assessment of the Rio Grande Rift, stated that the high heat-flow along the Rift is probably of magmatic and subcrustal origin rather than radiogenic. He (Corde11, 1978) believed that the high heat-flow is probably associated with a Pliocene age high-temperature anomaly at depth. Therefore, until proven other wise, it is assumed by the authors that the thermal waters of Shaws Warm Spring are of meteoric origin and are being heated by deep circulation in an area having above normal geothermal gradients.

An estimate to what depth these thermal waters might have circulated too can be made based on the geothermal gradient of the area plus the estimated reservoir temperature. It has been estimated that Shaw Warm Springs thermal system has a maximum subsurface reservoir temperature of $140^{\circ} \mathrm{F}$ (Barrett and Pearl, 1978). 
As noted earlier the geothermal gradient for this area is $1.9^{\circ} \mathrm{F} / 100 \mathrm{ft}$ $\left(35^{\circ} \mathrm{C} / \mathrm{km}\right)$. Therefore to reach these temperatures, it can be calculated that the waters would need to circulate to a depth of approximately 5,526 ft. $(1.7$ $\mathrm{km})$ below the recharge area.

In summary it can be concluded that the thermal waters of Shaw Warm Springs most likely are of meteoric origin. Some of the precipitation that fell on the surface of the 1 and became part of the ground waters of the area which migrated to depth along faults or other permeable channels in an area of above normal gradients. In so doing the waters became heated, then returned to the surface via fault zones or other permeable zones. 
An extensive geothermal energy resource assessment program was carried out in the vicinity of Shaws Warm Spring. Shaw Warm Springs, is located about 6 mi $(9.66 \mathrm{~km})$ north of Del Norte along the western side of the San Luis Valley in southcentral colorado. While thermal waters have been produced from water well s east of Del Norte, in the central part of the Valley, other than Shaw Warm Springs, no thermal waters have been reported along the west side of the Valley.

With the exception of the seismic geophysical survey, all the other surveys conducted in the vicinity of Shaw Warm Springs were successful, to one degree or another, in delineating the geological conditions controlling its occurrence. Shaws Warm Spring appear to be coming up from depth along a buried fault having no surface expression. Two of the electrical geophysical surveys gave contradictory interpretations of the geothermal conditions. The Schlumberger depth soundings demonstrated a shallow (<900 $\mathrm{ft}(274 \mathrm{~m})$ ) fault bounded reservoir located north of Shaw Warm Springs. On the other hand the deeper reading $(1,640 \mathrm{ft}(500 \mathrm{~m}))$ AMT survey did not locate any reservoir. As this contradiction was not apparent until after all field work had been completed no other measurements were made which might have resolved the problem.

From the best evidence available it appears that the thermal waters of Shaw Warm Springs are of meteoric origin, and became heated due to deep circulation $(<5,526 \mathrm{ft}, 1.7 \mathrm{~km})$ in an area having above normal geothermal gradients. The reservoir is probably small and limited in extent. Earlier estimates suggested that this thermal area might encompass no more than $0.63 \mathrm{sq} \mathrm{mi}(1.62 \mathrm{sq} \mathrm{km})$ and contain approx. $0.0148 \mathrm{Q}^{\prime} \mathrm{s}$ of heat energy at a temperature of $113^{\circ} \mathrm{F}\left(45^{\circ} \mathrm{C}\right)$. In light of the findings of this present study it is believed that those estimates are probably correct. Figure 22 summarizes findings of all the surveys conducted.

From all evidence gathered during the course of this investigation it appears that the only thermal waters along the western side of the San Luis Valley are those at Shaw Warm Springs. While this investigation centered on Shaw Warm Springs and the immediate adjacent area, no evidence was obtained to suggest that other thermal waters would be found at relatively shallow depths along the west side of the San Luis Valley. It was beyond the scope of this project to investigate the geothermal resources of the deep Monte Vista Graben, east of Shaw Warm Springs. From a cursory examination of the geological conditions of the Monte Vista Graben it appears that one could expect to find geothermal fluids in it at depth. 


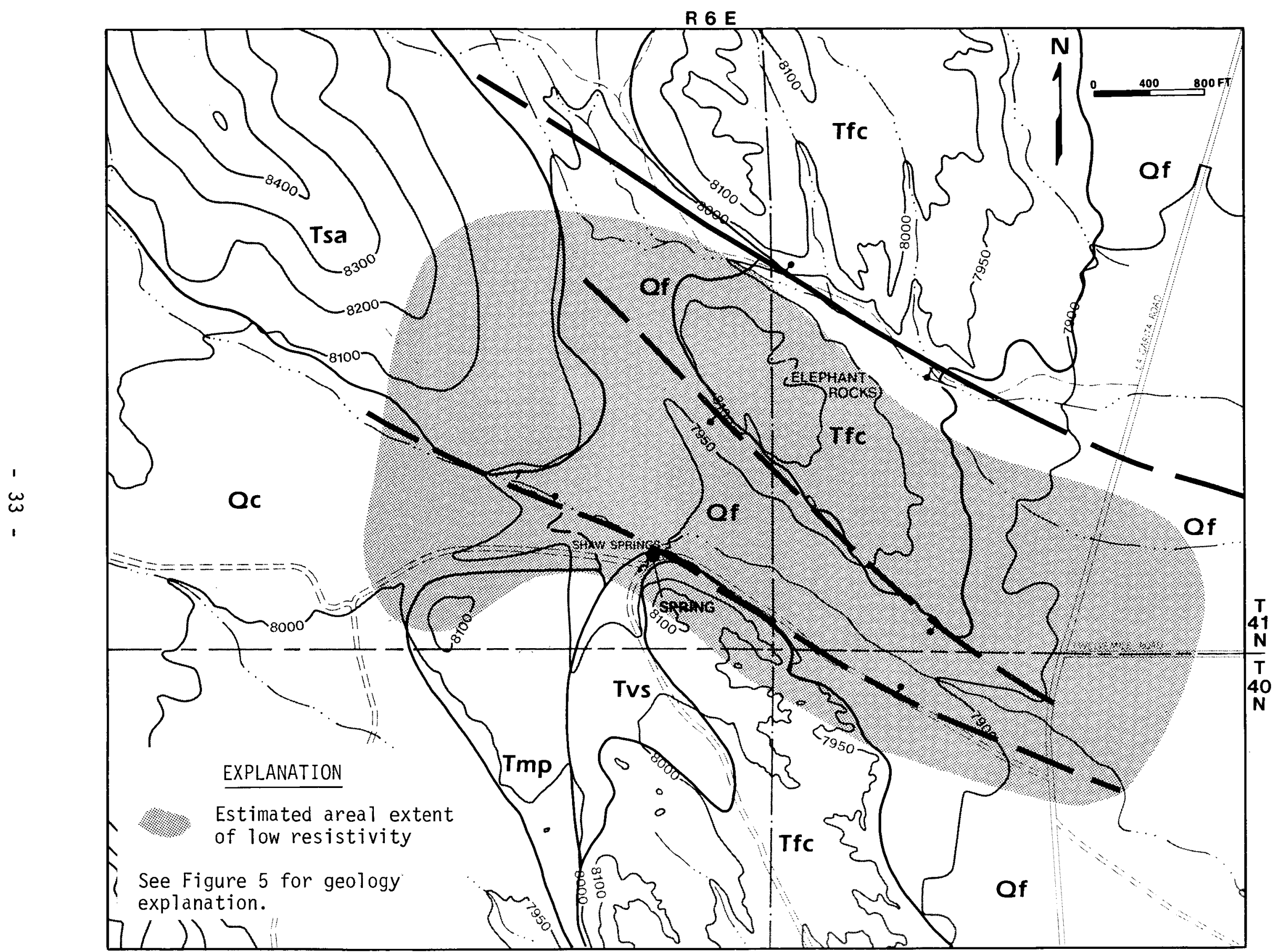

Figure 22. Shaw Springs, Colorado geothermal resource area map. 


\section{REFERENCES}

Anderson, D.N. and Lund, J.W., eds. (1979), Direct utilization of geothermal energy: A Technical Handbook: Geothermal Resources Council Spec. Rept. No. 7.

Applegate, J.K., 1981, Seismic reflection survey in the vicinity of Canon City, Colorado, and a review of seismic data gathered in the San Luis Valley; Final Report to Geophysics Fund, Inc.: Colorado School Mines, Explo. Research Lab., Unpublished report.

Barrett, J.K., and Pearl, R. H., 1976, Hydrogeological data of thermal springs and wells in Colorado: Colorado Geol. Survey Info. Series $6,124 \mathrm{p}$.

1978, An appraisal of Colorado's geothermal resources: Colorado Geo1. Survey Bul1. 39, 229 p.

Berry, G.W., Grim, P.J., and Ikelman, J.A., 1980, Thermal springs list for the United States: Nat. Oceanic and Atmospheric Adm, Key to geophysical records documentation No. 12, Boulder, C0., $59 \mathrm{p}$.

Bond, M. A., 1981, An integrated geophysical study of the Shaw Warm Springs area, San Luis Valley, South Central Colorado: Colorado School of Mines, Dept. of Geophysics, Unpub. MS Thesis T-2400, $162 \mathrm{p}$.

Burroughs, R.L, 1981, A summary of the geology of the San Luis Basin, Colorado-New Mexico with emphasis on the geothermal potential for the Monte Vista Graben: Colorado Geol. Survey Spec. Pub. 17, 30 p.

Capuano, R.M., and Bamford, R. W., 1978, Initial Investigation of Soil Mercury Geochemistry as an Aid to Drill Site Selection in Geothermal Systems, Contract EG-78-C-07-1701: Earth Science Lab., University of Utah Research Institute, Salt Lake City, Utah.

Chapin, C.E., 1979, Evolution of the Rio Grande Rift--A summary, in Rio Grande Rift: Tectonics and Magmatism, R.E. Riecker (ed): American Geophysical Union, Washington, D.C., pp. 1-5.

Christopherson, K.R., Nervick, K.H., Heran, W.D. and Pringle, Laure1, 1981, Audio-magnetotelluric and telluric profiling studies in the Shaw Warm Springs Region, Colorado: U.S. Geol. Survey Open-File Report.

Coe, B.A., 1978, Geothermal energy development in Colorado: Processes, Promises and Problems: Colo. Geol. Survey Info. Series 9, 52 p.

, 1980, Geothermal energy potential in the San Luis Valley, Colorado: Colorado Geol. Survey Open-File Report $80-13,44 \mathrm{p}$.

, 1982, Industrial market opportunities for geothermal energy in Colorado: Colorado Geol. Survey Spec. Pub. 20, 66 p.

Combs, James, 1981, Geothermal Exploration Strategy and Techniques, 1981: Geothermal Services Inc., San Diego, CA, $41 \mathrm{p}$. 
Corde11, Lindrith, 1978, Regional geophysical setting of the Rio Grande rift: Geo1. Soc. America Bu11. v. 89, p 1073-1090

Coury, G.E. and Vorum, Martin, 1978, San Luis Valley, Colorado: A region of high potential for geothermal development; in Direct Utilization of Geothermal Energy: A Symposium: Geothermal Resources Council, Davis, CA, pp. $71-78$.

Cox, M. E., and Cuff, K. G., 1980, Rn and Hg Surveys: Geothermal Exploration in N.E. Maui Hawaij in Geothermal: Energy for the Eighties, Transactions GeothermaT Resources Council Annual Meeting, Salt Lake City, UT: Geothermal Res. Council, Davis, CA, p. 451-454.

Craig, H.G., 1961, Isotopic variations in meteoric waters: Science, v. 133 , pp. 1702-1703.

Craig, H.G., Boato, G., and White, D.E., 1956, Isotopic geochemistry of thermal waters: National Research Council, Nuclear Science Series Report 19, pp. 29-38.

Decker, E.R. and Bucher, G.J., 1979, Thermal gradients and heat flow in Colorado and Wyoming: Loas Alamos Sci. Lab., LA 7993-MS, p. 1-9

Emery, P.A., Boettcher, A.J., Snipes R.J. and McIntyre, H.J., Jr., 1971, Hydrology of the San Luis Valley, south-central Colorado: U.S. Geol. Survey Hydro. Inv. Atlas HA-381.

Emery, P.A., Snipes, R.J., Dumyer, J.M., and Klein, J.M., 1973, Water in the San Luis Valley, south-central Colorado: Colorado Water Conserv. Board, Circ. No. 18, 26 p.

George, R. D., Curtis, H. A., Lester, 0. C., Crook, J. K., and Yeo, J. M., 1920, Mineral waters of Colorado: Colorado Geol. Survey Bull. $11,474 \mathrm{p}$.

Goering, S.W. and Connor, F.R., 1980, Geothermal-based industrial park development in south-central Colorado; in Geothermal Energy for the Eighties, Transactions Geothermal Resources Council Annual Meeting, Salt Lake City, UT: Geothermal Res. Council, Davis, CA, pp. 565-567.

Goering, S.W., Coury, G.E. and Garing, K.L., 1979a, An analysis of the design, economics and federal tax impacts of proposed geothermal greenhouse operations near the Baca Grande development, San Luis Valley, Colorado; in Expanding the Geothermal Frontier, Transactions Geothermal Resources Council Annual Meeting, Reno, NV: Geothermal Resources Council, v. 3, Davis, CA, pp. 253-256. ,1979b, Geothermal energy applications to the barley malting industry in the San Luis Valley, Colorado: ASHRAE Transactions, 85(1), pp. 951-964. 
Goering, S.W., Garing, K.L. Coury, G.E. and Fritzler, E.A., 1980 , Residential and commercial space heating and cooling with possible greenhouse operation; Baca Grande development, San Luis Valley, Colorado, Final Report: U.S. Dept. of Energy ID/78-ET28455-3, Idaho Falls, ID, $282 \mathrm{p}$.

Gwinn, Cindy, 1981, Heat flow measurements in the San Luis Valley and Canon City areas, Colorado: Dept. of Geol. Sciences, Southern Methodist Univ., Dallas, TX, Unpublished Report,

Harder, Vicki, Morgan, Paul and Swanberg, C.A., 1980, Geothermal resources in the Rio Grande Rift: Origins and Potential; in Geothermal Energy for the Eighties; Transactions Geothermal Resources Council Annual Meeting, Salt Lake City, UT: Geothermal Resources Council, Davis, CA., pp. $61-64$.

Huntley, David, 1975, Evaluation of the Skylab photography for water resources San Luis Valley, Colorado: Remote sensing report 75-7, Dept. of Geol., Colorado School Mines, 38 p.

James, H.L. (ed.), 1971, Guidebook of the San Luis Basin, Colorado: New Mexico Geological Society Twenty-second Field Conference, $325 \mathrm{pp}$.

Jordan, J.M., 1974, Geothermal investigations in the San Luis Valley, Colorado: Colorado School Mines, Dept. of Geological Eng., Master Sci. Thesis, $89 \mathrm{p}$.

Klusman, R. W., and Landress, R. A., 1979, Mercury in soils of the Long Valley, California, Geothermal System: Jour. Volcanology, Geothermal Res., v. 5, pp. 49-65.

Klusman, R. W., Cowling, S., Culvey, B., Roberts, C., and Schwab, A. P., 1977, Preliminary evaluation of secondary controls on mercury in soils of geothermal districts: Geothermics, v. 6, pp. 1-8.

Kruger, Paul, and 0tte, Carl, eds., 1973, Geothermal energy--resources, production, stimulation: Stanford Univ. Press, $360 \mathrm{p}$.

Lepeltier, Clande, 1969 , A simplified statistical treatment of geochemical data by graphical representation: Economic Geology, vo1. 64 , pp. 538-550.

Levinson, A. A., 1974, Introduction to exploration geochemistry: Applied Publishing Ltd., Calgary, pp. 561-568.

Lewis, E. L., 1966, The thermal springs of Colorado--A resource appraisal: Univ. of Colorado Dept. Geography, Master Sci. Thesis. 91 p.

Lipman, P. W., 1976, Geology of the Summer Coon volcanic center, eastern San Juan Mountains, Colorado; in Cenozoic volcanism in the southern Rocky Mountains, Epis, R.C. (edT: Colorado School Mines Quart., v v. 63, , no. 3, p 211-236. 
Lipman, P.W., 1976, Geologic map of the Del Norte area, eastern San Juan Mountains Colorado: U.S. Geol. Survey Misc. Inv. Series, Map I-952 Scale $1: 48,000$.

Lipman, P.W. and Mehnert, H.H., 1975, Late Cenozoic basaltic volcanism and development of the Rio Grande Depression in the Southern Rocky Mountains; in Cenozoic History of the Southern Rocky Mountains, B.F. Curtis (ed): Geol. Soc. America Memoir 144, pp. 119-154.

Mallory, E. C., Jr., and Barnett, P. R., 1973, Chemistry and spectrochemical analysis of selected groundwaters in Colorado: U.S. Geol. Survey Open-File Report, $47 \mathrm{p}$.

Matlick, J. S. III, and Buseck, P. R., 1976, Exploration for geothermal areas using mercury - a new geochemical technique; in Proceedings Second United Nations Symposium on the Development and Use of Geothermal Resources, San Francisco, CA.: U.S. Gov. Printing office, v. 1, pp. 785-792.

Mertzman, S.A., Jr., 1971, The Summer Coon volcano, eastern San Juan Mountains, Colorado; in Guidebook of the San Luis Basin, Colorado: New Mexico Geol. Soc. 22nd Field Conference, p. 265-275.

Miesh, A. T., 1976, Sampling Designs for Geochemical Surveys - syllabus for a short course: U.S. Geol. Surv. Open-File Report 76-772.

Muffler, L.J.P., ed., 1979, Assessment of geothermal resources of the United States--1978: U.S. Geol. Survey Circular 790, 163 p.

Meyer, R.T. and Roberts, S.G., 1979, Economic analysis of geothermal energy options for the Baca Grande development: Western Energy Planners, Denver, CO.

Pearl, R. H., 1972, Geothermal resources of Colorado: Colorado Geol. Survey Spec. Pub. 2, 54 p.

1979, Colorado's hydrothermal resource base--An assessment: Colorado Geol. Survey Resource Series 6, $144 \mathrm{p}$.

Pear1, R.H. and Barrett, J.K., 1976, Geothermal resources of the upper San Luis Valley and Arkansas Valley, Colorado; in Studies in Colorado

Field Geology, R.C. Epis and R.J. Weimer (eds.): Colorado School Mines, Prof. Contributions No. 8, Golden, CO, pp. 439-445.

Powell, W.J., 1958, Ground water resources of the San Luis Valley, Colorado: U.S. Geol. Survey Water Supply Paper 1379, 284 p.

Riecker, R.E. (ed)., 1979, Rio Grande rift: Tectonics and magmatism: American Geophysical Union, Wash. D.C., 438 pp.

Ringrose, C.D., 1980, Temperature--depth profiles in the San Luis Valley and Canon City areas, Colorado: Colorado Geol. Survey Open-File Rept. $80-12,18 \mathrm{p}$. 
Repplier, F.N. and Fargo, R.L., 1981, Geothermal gradient map of Colorado: Colorado Geo1. Survey Map Series 20, Scale 1:1,000,000.

Romero, John and Fawcett, Donald, 1978, Geothermal resources of southcentral Colorado and their relationship to ground and surface water: Colorado Div. of Water Resources, $127 \mathrm{p}$.

Scintrex, 1971, RAC-8 10w frequency A.C. resistivity system operation manua 1: Concord, Ontario, Canada, $22 \mathrm{p}$.

Soil Test Inc., 1968, Earth resistivity manual: Evanston, I1linois, 52 p.

Sumner, J. S., 1976, Principles of induced polarization for geophysical exploration: Elsevier Scientific Publishing Company, pp. 1-47.

Tweto, Ogden, 1975, Laramdide (Late Cretaceous-Early Tertiary) orogeny in the Southern Rocky Mountains; in Cenozoic History of the Southern Rocky Mountains, B.F. Curtis ( $\overline{e d})$ : Geol. Soc. America Memoir 144, pp. 1-44.

, 1979, The Rio Grande Rift System in Colorado; in Rio Grande Rift: Tectonics and Magmatism, R.E. Riecker (ed): American Geophysical Union, Washington, D.C., pp. 33-56.

Vorum, Martin, Coury, G.E., Goering, S.W., and Fritzler, E.A., 1978, Non-electric utilization of geothermal energy in the San Luis Valley, Colorado, Final Report: U.S. Dept. of Energy Report No. ID/1626-3, Idaho Fails, ID, $157 \mathrm{p}$.

Waring, G. A., 1965, Thermal springs of the United States, and other countries of the world- -A summary, revised by R.F. Blankenship and Ray Bentall: U.S. Geol Survey Prof. Paper 492, 383 p.

White, D. E., 1967, Mercury and base-metal deposits with associated thermal and mineral waters, in Geochemistry of Hydrothermal Ore Deposits, H.L. Barns, (ed.): Holt, Rinehart and Winston, New York, pp. 575-631.

White, D.E. and Williams, D.L., eds., 1975, Assessment of geothermal resources of the United States--1975: U.S. Geo1. Survey Circular 726, $155 \mathrm{p}$.

White, D. E., Hinkle, L. G., and Barnes, I., 1970, Mercury content of natural thermal and mineral fluids: U.S. Geol. Survey Prof. Paper 713 , pp. $25-28$.

Zacharakis, T. G., 1981, Revised heat flow map of Colorado: Colorado Geol. Survey Map Series 18, scale 1:1,000,000.

Zeisloft, Jon and Mackelprang, C.E. (in prep), Case study of User Coupled Confirmation Drilling Project (D.O.E) at Alamosa, Colorado: Earth Science Lab, Univ. of Utah Research Inst., Salt Lake City, UT. 


\section{APPENDIX A}

\section{GEOTHERMAL ENERGY AND ITS POSSIBLE USES}

Geothermal energy, the heat generated by natural processes beneath the earth's surface normally occurs at great depths. In some places, however it $c$ an be found close to or at the surface in the form of volcanoes, geysers or hot springs. Where it occurs near the surface it can be developed and put to beneficial use. Geothermal energy in the form of hot springs has been used by mankind for medicinal and cooking purposes since the earliest days of recorded history. In the last 100 years development of this energy source for other uses has occurred, and it is now used for such purposes as: Generation of electricity; heating and cooling of buildings; processing of food and other goods; heating cattle barns, greenhouses and fish ponds; milk pasteurization; and recreation and medicinal purposes. Due to declining petroleum reserves it is anticipated that in years to come development of this energy source will increase. Figure 23 lists some of the uses geothermal energy could be put to and the temperatures required.

Coe (1978 and 1982) has presented a discussion on the possible uses, of geothermal energy development in Colorado and some of the problems associated with its development. For those interested in learning more about geothermal enery and its possible development they are referred to papers by: Anderson and Lund (1979); Kruger and 0tte (1973); Muffler (1979); and White and Williams (1975). Listed on the back cover is a complete listing of all papers and reports published by the Colorado Geological Survey relating to the geothermal resources of Colorado. 


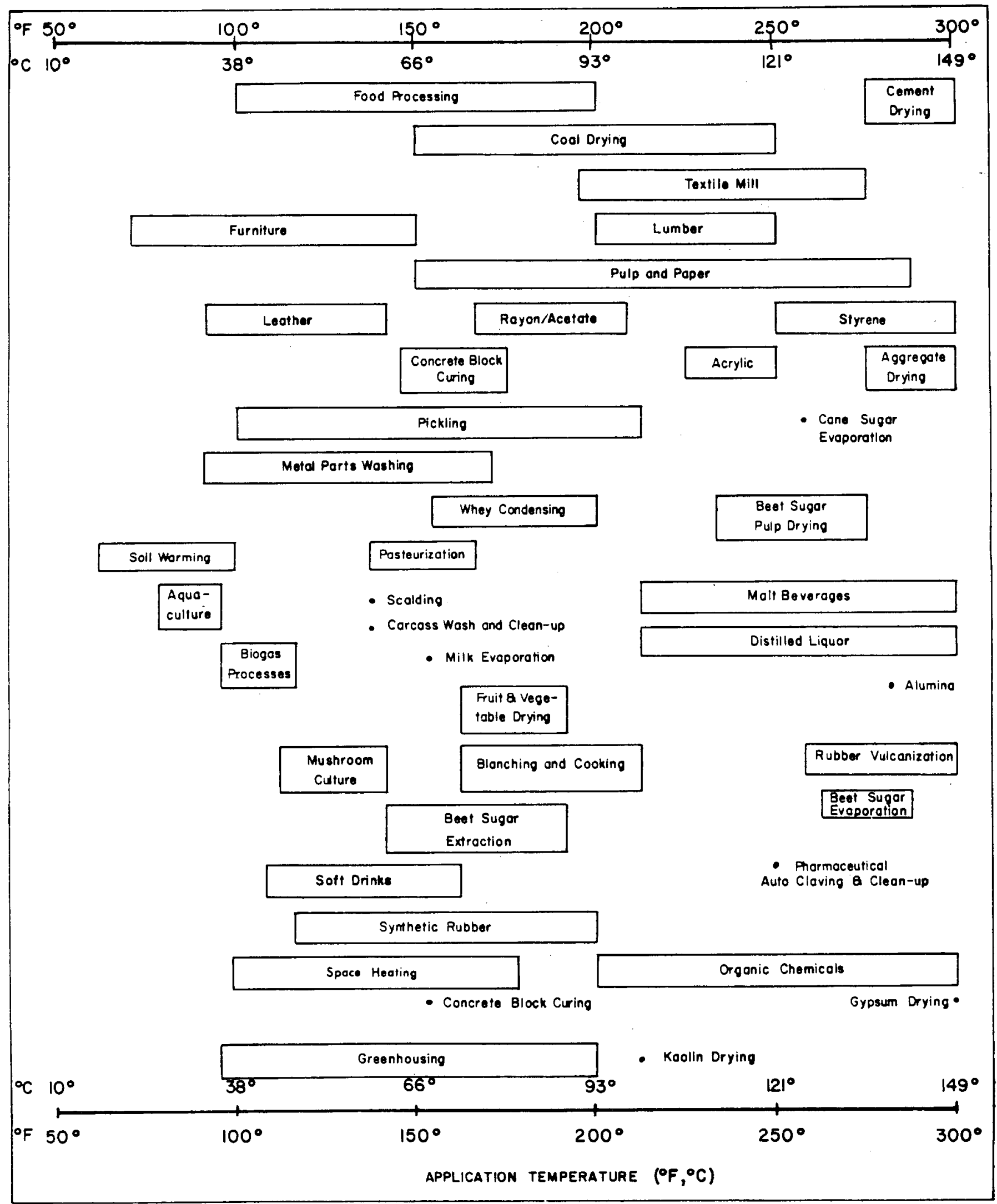

Figure 23. Temperature range for some direct uses of geothermal energy. (Adopted from Anderson and Lund, 1979). 
APPENDIX B. SHAW WARM SPRINGS THERMAL WATERS

Table 4. Physical properties and chemical analysis of Shaw Warm Springs.

\begin{tabular}{|c|c|c|c|c|}
\hline & \multicolumn{4}{|c|}{ Date Sampled } \\
\hline & $8 / 75$ & $10 / 75$ & $1 / 76$ & $4 / 76$ \\
\hline Arsenic, $(U G / L)$ & 0 & 0 & & - \\
\hline Boron, $(U G / L)$ & 130 & 140 & 120 & 270 \\
\hline Cadium, (UG/L) & 0 & 0 & - & - \\
\hline Calcium, (MG/L) & 0.9 & 0.5 & 2.7 & 0.9 \\
\hline Chloride, $(M G / L)$ & 7.5 & 7.2 & 7.3 & 7.0 \\
\hline Fiuoride, (MG/L) & 3.1 & 2.9 & 3.0 & 4.2 \\
\hline Iron, $(U G / L)$ & 40 & 20 & 10 & 0 \\
\hline Lithium, (UG/L) & 10 & 10 & - & - \\
\hline Magnesium, (MG/L) & 0.6 & 0.3 & 0.7 & 0.1 \\
\hline Manganese, (UG/L) & 0 & 0 & 0 & 10 \\
\hline Mercury, (UG/L) & 0 & 0 &  & \\
\hline Nitrogen, (MG/L) & 0.01 & 0.02 & 0.02 & 0.01 \\
\hline \multicolumn{5}{|l|}{ Phosphate } \\
\hline Ortho diss. as $P,(M G / L)$ & 0.04 & 0.03 & 0.05 & 0.04 \\
\hline Ortho, (MG/L) & 0.12 & 0.09 & 0.15 & 0.12 \\
\hline Potassium, (MG/L) & 1.5 & 1.4 & 1.5 & 1.5 \\
\hline Selenium, (UG/L) & 0 & 0 & & -0 \\
\hline Silica, (MG/L) & 83 & 73 & 100 & 76 \\
\hline Sodium, (MG/L) & 130 & 130 & 130 & 130 \\
\hline Sulfate, $(M G / L)$ & 50 & 53 & 46 & 46 \\
\hline Zinc, $(U G / L)$ & 0 & 0 & ro & ro \\
\hline \multicolumn{5}{|l|}{ Alkalinity } \\
\hline As Calcium Carb., (MG/L) & 214 & 222 & 221 & 219 \\
\hline As Bicarbonate, $(M G / L)$ & 121 & 114 & 154 & 127 \\
\hline \multicolumn{5}{|l|}{ Hardness } \\
\hline Noncarbonate, (MG/L) & 0 & 0 & 0 & 0 \\
\hline Total, (MG/L) & 5 & 2 & 10 & 3 \\
\hline \multirow{2}{*}{\multicolumn{5}{|c|}{$\begin{array}{l}\text { Specific Conductance } \\
\text { (Micromohs) }\end{array}$}} \\
\hline & 550 & 540 & 569 & 556 \\
\hline $\begin{array}{l}\text { lotal Dissolved } \\
\text { Solids (MG/L) }\end{array}$ & 406 & 402 & 424 & 398 \\
\hline ph, Field & 9.3 & 9.3 & 9.0 & 8.9 \\
\hline Discharge (gpm) & 34 & 34 & 52 & 40 \\
\hline Temperature $\left({ }^{\circ} \mathrm{C}\right)$ & 30 & 30 & 30 & 30 \\
\hline
\end{tabular}

Location: SE, SE, Sec. 33, T. 41 N., R. 6 E., New Mexico Principal Meridan.

Remarks: Carbonate content: $69 ; 77 ; 57$; and $69 \mathrm{mg} / 1$ respectively. Source of data: Barrett and Pearl (1976) 


\section{APPENDIX C}

\section{FACTORS AFFECTING RESISTIVITY}

One of the more favorable techniques used in geothermal resource exploration are electrical geophysical surveys. The basic prinicipal behind this method is that the resistence of the subsurface rocks to the passage of an electrical current can be measured. The method used by the Colorado Geological Survey involves inducing a man made electrical current into the subsurface and measuring the resultant potential at two receiving electrodes (Soil Test Inc., 1968). A complete description of the equipment and field procedures used is presented in Appendecies $D$ and $E$.

The transmission of the electrical current is dependent upon such factors as: 1) subsurface temperature; porosity of the rocks; 2) salinity of fluids contained in the rocks; and 3) clay content of the rocks. As these factors tend to be higher in geothermal systems than non geothermal systems the geothermal systems are distinguished by lower resistence measurements than the surrounding areas. However, it must be kept in mind that under favorable conditions non thermal areas may be confused with thermal area. For example a low temperature, highly saline ground water can provide the same readings as a high temperature, moderately saline geothermal fluid. Therefore, to be most effective, electrical resistivity surveys should be used in conjuction with other methods, such as gradient temperature measurements, that are of value in determining the reason for the resistivity measurements recorded.

During the course of its investigations The Colorado Geological Survey, employed the method of man induced electrical currents. A complete description of the equipment and field procedures used are presented in Appendecies $D$ and E. 


\section{APPENDIX D}

\section{SC INTREX RAC-8 LOW FREQUENCY RESISTIVITY SYSTEM}

The following description of the Scintrex RAC-8 electrical resistivity equipment used by the Colorado Geological Survey is taken from the Scintrex Manual (1971). The Scintrex RAC -8 is a very low frequency AC resistivity system with high sensitivity over a wide measuring range. The transmitter and receiver operate independent of each other, requiring no references wires between them. This allows a great deal of efficiency and flexibility in field procedures and eliminates any possibility of interference from current leakage or capacitive coupling within the system.

The transmitter produces a $5 \mathrm{~Hz}$ square wave output at a preset electronically stabilized, constant current amplitude. The output current level is switch selectable at any one of five values ranging from 0.1 to 333 milliamps.

The receiver is a high sensitivity phase lock, synchronous detector which locks onto the transmitter signal to make the resistivity measurement. When set at the same current setting as the transmitter, the receiver gives a direct readout of $V / I$ ratio.

The $\mathrm{RAC}-8$, with a measuring range from .0001 to 10,000 ohms, high sensitivity to weight ratio, gives fast, accurate resistivity data. With the low $A C$ operating frequency, good penetration may be obtained in excess of $1500 \mathrm{ft}$ under favorable conditions. The system has an output voltage maximum $1000 \mathrm{~V}$ peak to peak. However, the actual output voltage depends on the current level and load resistance. The output power under optimum conditions approaches 80 watts.

In areas of very low resistive 1 ithology, the penetration power was reduced by a sizeable amount. Realizing the aforementioned constraint, the intent was to del ineate gross differences in resistivity. In some areas where the lithology reflected small differences in resistivity, the RAC-8 system appeared to average the penetrated lithologic sequences rather than picking up distinct breaks. Considering cost and time constraints, the system performed as indicated and performed best in areas of high resistivity. 


\section{APPENDIX E \\ RESISTIVITY FIELD PROCEDURES}

Introduction

One of the most widely used electrical processing techniques for geothermal resource exploration is the resistivity profiling and sounding method. The method utilizes various arrays, but the most common are the Wenner, the Schlumberger and the Dipole-Dipole schemes. The Colorado Geological Survey extensively employed the latter method primarily because of the ease of use and also being able to obtain horizontal and vertical sections.

Before discussing the various electrode methods used, it is necessary to consider what is actually measured by an array of current and potential electrodes (Fig. 24). By measuring (V) and current (I) and knowing the electrode configuration, a resistivity $(p)$ is obtained. Over homogeneous isotropic ground this resistivity will be constant for any current and electrode arrangement. That is, if the current is maintained constant and the electrodes are moved around, the potential voltage (V) will adjust at each configuration to keep the ratio (V/I) constant (Sumner, 1976).

If the ground is nonhomogeneous, however, and the electrode spacing is varied, or the spacing remains fixed while the whole array is moved, then the ratio will in general change. This results in a different value of $P$ for each measurement. Obviously, the magnitude is intimately involved with the arrangement of electrodes.

This measured quantity is known as the apparent resistivity, Pa. Although it is diagnostic of the actual resistivity of a zone in the vicinity of the electrode array, this apparent resistivity is definitely not an average value. Only in the case of homogeneous ground is the apparent value equivalent to the actual resistivity (Sumner, 1976).

The following formula is used by all methods to calculate the apparent resistivity at a site.

General Resistivity Formula

$$
P_{a}=2 P I a V / I
$$

$$
\begin{aligned}
\mathrm{a} & =\text { Spread length } \\
\mathrm{V} / \mathrm{I} & =\text { Voltage current ratio } \\
\mathrm{Pa} & =\text { apparent resistivity } \\
2 \mathrm{PI} & =6.2
\end{aligned}
$$


In the Wenner Spread (Fig. 25) the electrodes are uniformly spaced in a line (Sumner, 1976). In spite of the simple geometry, this arrangement is often quite inconvenient for field work and has some disadvantages from the theoretical point of view as well. For depth exploration using the Wenner Spread, the electrodes are expanded about a fixed center, increasing the spacing in steps. For lateral exploration or mapping the spacing remains constant and all four electrodes are moved along the line, then along another line, and so on. In mapping, the apparent resistivity for each array position is plotted against the center of the spread.

\section{Schl umberger Array}

For the Schlumberger array, the current electrodes are spaced much further apart than the potential electrodes (Fig. 26).

In depth probing the potential electrode remains fixed while the current electrode spacing is expanded symmetrically about the center of the spread. For large values of $L$ it may be necessary to increase $2 \times 1$ also in order to maintain a measurable potential. This procedure is more convenient than the Wenner expanding spread because only two electrodes need move. In addition, the effect of shallow resistivity variations is constant with fixed potential spread (Sumner, 1976 ).

In summary, short spacing between the outer electrodes assumes shallow penetration of current flow and computed resistivity will reflect properties of shallow depth. As the electrode spacing is increased, more current penetrates to greater depth and conducted resistivity will reflect properties of each material at greater depth. This method was used on a few lines for sampling purposes in array. 


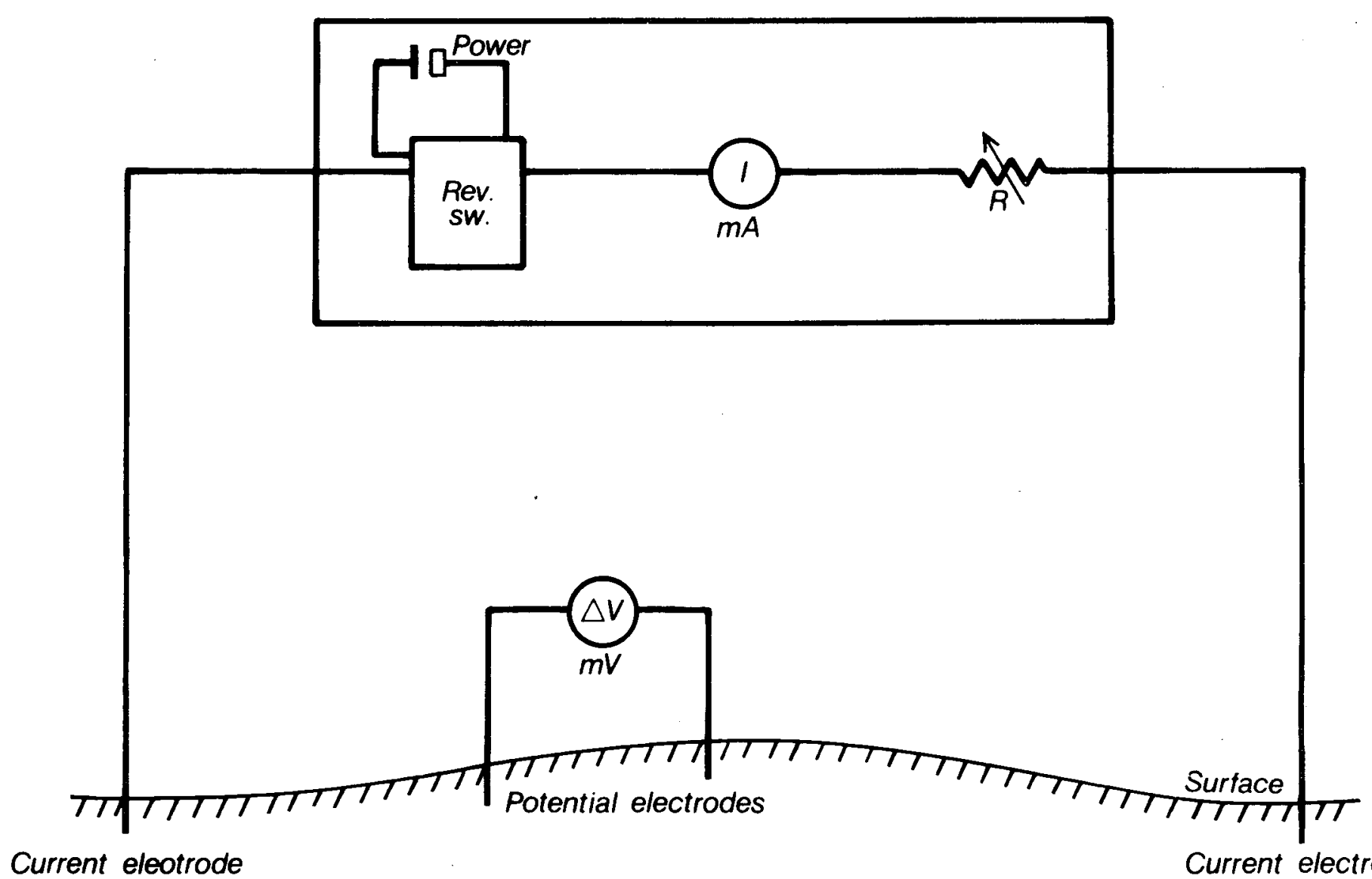

Current eleotrode

Current electrode

Figure 24. Schematic diagram for resistivity (from Combs, 1980).

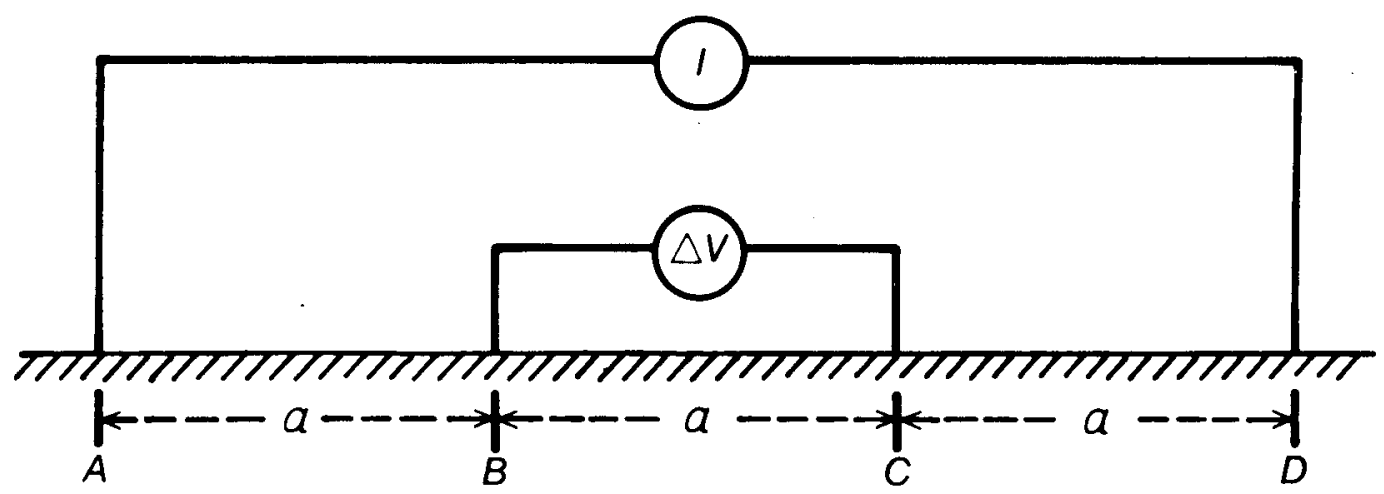

Current electrode Potential electrode Potential electrode Current electrode

$$
\rho_{a=2 \pi a(\Delta v / I)}
$$

Figure 25. Wenner array (from Combs, 1980). 


\section{Dipole-dipole Array}

The potential electrodes are closely spaced and remote from the current electrodes which are close together. There is a separation between $C$ and $P$, usually 1 to 5 times the dipole lengths (Fig. 27).

Inductive coupling between potential and current cables is reduced with this arrangement. This method was primarily used throughout all study areas because of reliability and ease of field operation. A diagram of this method is depicted in Figures 28 and 29.

With reference to Figures 28 and 29 , an in-line 100 foot dipole-dipole electrode geometry was used. Measurements were made at dipole separations of $n$ $=1,2,3,4,5$. The apparent resistivities have been plotted as pseudosections, with each data point being plotted at the intersections of two lines drawn at $45^{\circ}$ from the center of the transmitting and receiving dipoles. This type of survey provides both resolution of vertical and horizontal resistivity contrasts since the field procedures generate both vertical sounding and horizontal profile measurements. The principal advantage of this technique is that it produces better geologically interpretable results than the other two methods (Wenner, Schlumberger). In addition, the dipole-dipole array is easier to maneuver in rugged terrain than either of the other methods. Its main disadvantage compared to the Schlumberger array is that is usually requires more current, and therefore a heavier generator for the same penetration depth. Another disadvantage of this method is that it is very difficult to make an accurate interperation from the data collected (Sumner, 1976 ). 


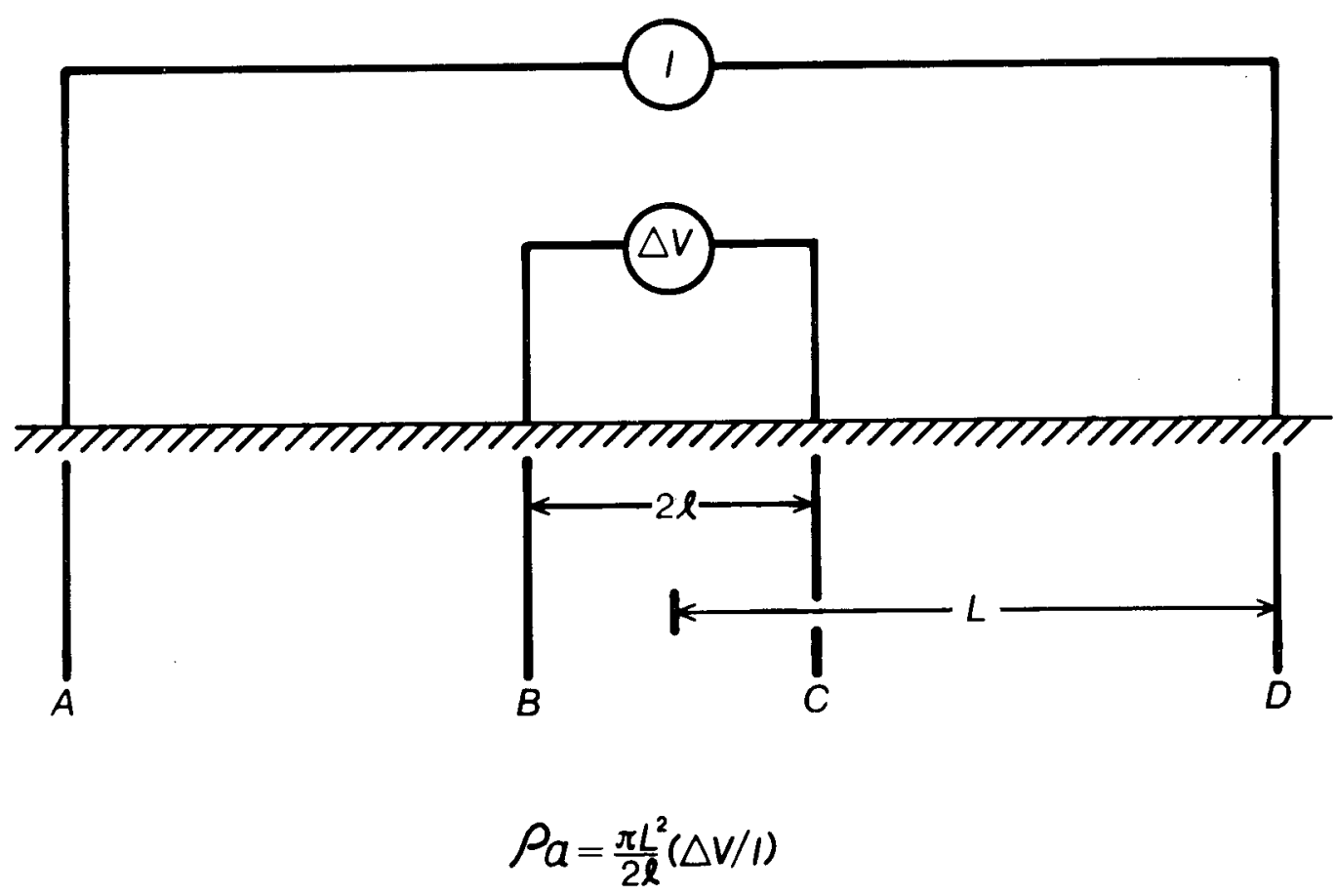

Figure 26. Schlumberger array (from Combs, 1980).
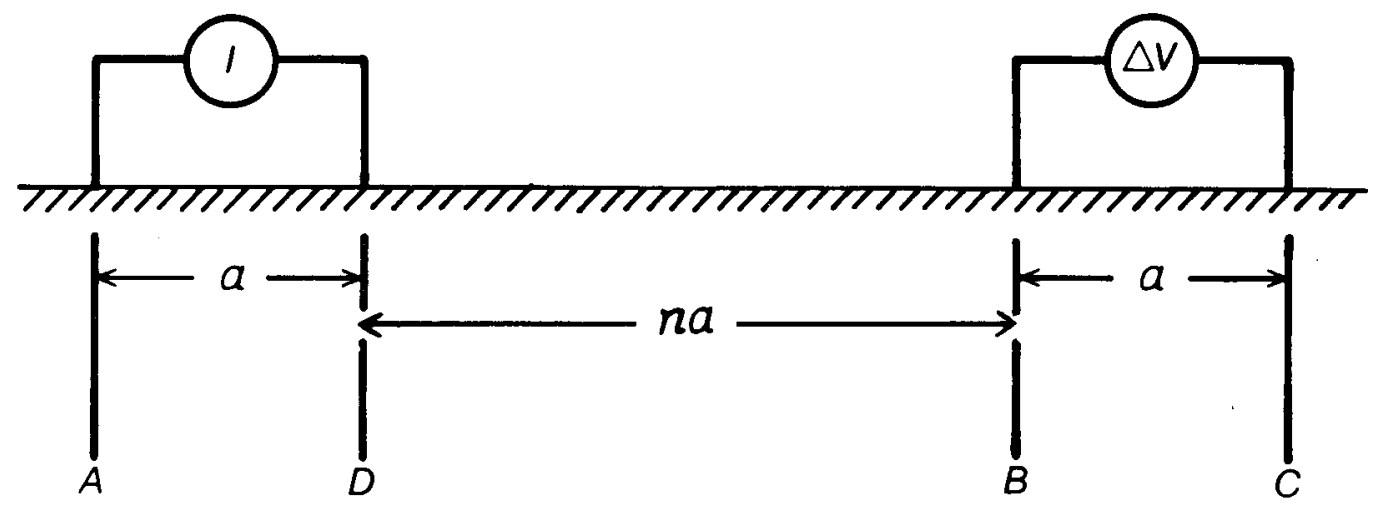

$\rho_{a=\pi n(n+1)(n+2) a(\Delta V / l)}$

Figure 27. Dipole-dipole array (from Combs, 1980). 




Figure 28. Data plotting scheme for dipole-dipole array (from Combs, 1980).
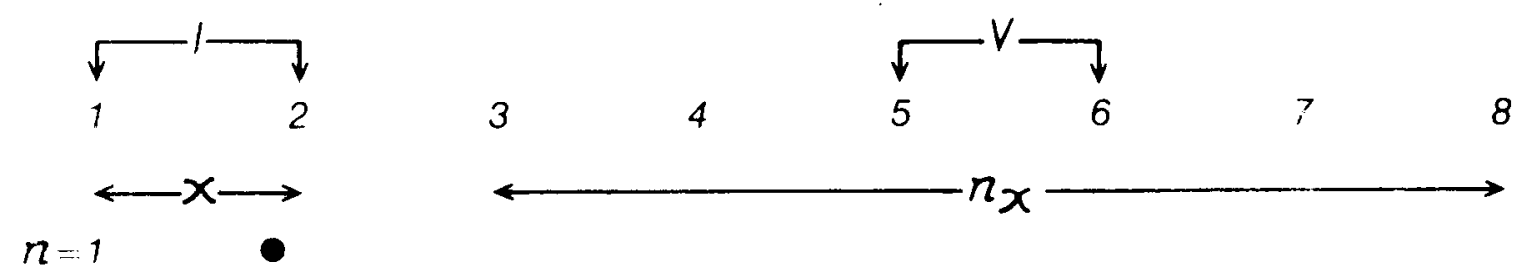

9

10

$n=1$

2

3

4

.

$x$ Electrode Spread

$n$ Electrode Seperation

1 Transmitter

$\checkmark$ Receiver

5

Figure 29. Typical dipole-dipole array (from Combs, 1980 ). 


\section{APPENDIX F \\ SOIL MERCURY SURVEYS \\ Strategy and Methodology}

The aim of the geochemical sampling program by the Colorado Geological Survey was to evaluate those thermal areas deemed to have high commercial development potential. As the time allotted for this program was limited, the soil mercury surveys had to be preliminary in nature. The geochemical sampling program started in 1979 and continued into 1980. The surveys conducted during the summer of 1979 were aimed at determining the structural conditions controlling the hot springs. This approach was strongly influenced by the work of Capuano and Bamford (1978). In 1980 a broader sampling target was selected. Rather than just sampling along traverses located over suspected faults, grid sampling patterns were used. If anomalous mercury concentrations were detected, then follow-up samples were collected at a more detailed level. For those thermal areas where grid sampling was not possible due to lack of access, soil disturbance, or urban development, traverses were chosen in a similar method to the procedure used in 1979.

During the course of the investigations the following restrictions became apparent: urban development; alluvial and colluvial deposits; and mining areas. In urban developments one cannot really be sure whether the surface deposits in the back streets and lawns are original or have been brought in. In sampling alluvial and colluvial surficial deposits such deposits because of their origin, age and mineral content tend to mask, dilute, and/or distort any anomalies. In old mining area the problem becomes whether the mercury concentrations found are caused by mineralization or by geothermal actitivty.

\section{Sampling Methods}

At selected sample sites, one to eight samples were taken at points within 15 to $20 \mathrm{ft}$ of each other. The notation of sampling locality is explained in Miesch (1976). The interval between sampling sites depends on the target being considered. For areas investigated, the sample site interval was either $100 \mathrm{ft}$ to $200 \mathrm{ft}$ or $400 \mathrm{ft}(30 \mathrm{~m}$ to $61 \mathrm{~m}$ or $122 \mathrm{~m})$. When using a $400 \mathrm{ft}(122 \mathrm{~m})$ interval, the area in the immediate vincinity of the hot spring was considered the target rather than any particular fault. Sampling intervals of $200 \mathrm{ft} / 61$ $\mathrm{m})$ or less were used where attempts were made to delineate controlling faults. This spacing was used by Capuano and Bamford (1978). However, Klusman and Landress (1979) seem to think that the sample must be taken directly over the faulting for detection. Considering the empirical result of Capuano and Bamford (1978), it was believed that some anomalous mercury values should be encountered if a grid pattern encompassing the hot spring area was used. A definite structural pattern may be obvious, but if the study area is being influenced by geothermal activity, the trend should indicate that the hot sprins area entirely or partially is high in mercury relative to surrounding area.

The sampling procedure used during 1979 consisted of laying out a series of samples lines across suspected faults in the thermal areas. Samples were collected at predetermined intervals (usually $100 \mathrm{ft}$ ) along the lines. 
In most of the areas investigated during 1980, three or more samples were taken at random sample localities. This was done to get an estimate of how the variance between sample localities compared with the variance at a sample locality. If the comparison suggested that there is as much variance at a sample locality as there is between sample localites, then the data would than likely lead to false interpretation.

Two rationales have been used for determining the sampling depth. The method recommended by Capuano and Bamford (1978) is to determine the profile of mercury down to a depth of approximately 16 in $(40 \mathrm{~cm})$, the depth at which the profile peaks determines the sampling depth. The other method consistently samples a soil horizon, such as the $A$ or B horizon. The problem with using the A horizon is that its normally high organic content has been shown to have strong secondary effects in controlling mercury in the soil. Also, the sampling depth in the $A$ horizon may not be deep enough to avoid the "baking" effect of the sun.

The method used during 1979 consisted of using profiles to determine sampling depths. A sampling depth of approximately 6 in $(15 \mathrm{~cm})$, with an interval of about 0.4 in $(1 \mathrm{~cm})$, was used for most of the profiles. During 1980 each sample was taken over an interval of 5 to 7 in $(13$ to $18 \mathrm{~cm})$. It was hoped that some of variance due to depth would be smoothed out by sampling over a wider interval. Also, at that depth it was hoped that the sun would not be affecting the soil's ability to retain mercury.

To collect a sample, the ground was broken with a shovel to a depth of 9 to 10 in $(20$ to $25 \mathrm{~cm})$. Then a spatula and metal cup were used to collect approximately 100 grams of material. The contents of the cup were then put in a marked plastic bag. At the end of the day the material in each bag was laid out and allowed to dry overnight. Sometimes it would take more than one night to dry. Normally, the following morning the dried material would be sieved down to an 80 mesh size outside in a shaded area and stored in $4 \mathrm{ml} \mathrm{glass}$ vials with screw caps. Within a period of seven days later, the samples were analyzed for mercury using the Model 301 Jerome gold film mercury detector.

\section{Analysis}

For an accurate analysis of geochemical data, it is necessary to differentiate between background and anomalous values. There are various statistical ways of accomplishing this. For those areas where the statistical sample approaches 100 samples and a lognormal distribution can be assumed, a method which looks for a break in the cumulative frequency plot of the mercury data can be used. Hopefully, the break distinguishes the two populations -- the background and the geothermal induced population (Capuano and Bamford, 1978; Lepelitor, 1969; and Levinson, 1974 ).

For those instances where the data was analyzed using a cumulative frequency diagram, the following procedure was used.

1). Determine the number of class intervals by multiplying the logarithm of the number of the samples by 10 .

2). Determine the range of each class interval by dividing the maximum recorded value, by the class interval less one. 
3). Determine logarithm of top end of each interval.

4). Determine class frequency by calculating the number of values in each class.

5). Determine relative frequency by dividing each class frequency value by total number of values.

6). Construct frequency distribution graph by plotting class frequency log values by cumulative frequency.

7). Note where break in slope of graph occurs.

To demonstrate this method, assume that 90 samples had been collected and analyzed with analytical values ranging from $0 \mathrm{ppb}$ to $900 \mathrm{ppb}$. 1) To determine the class interval, multiple the $\log$ of 90 by 10 (C.I. $=10 \log 90=19$ intervals). 2). To determine the range of each class interval divide 900/18. C.I. range $=50 \mathrm{ppb} .3$ ) Determine $10 \mathrm{~g}$ of each class interval: $10 \mathrm{~g} 49=1.69$; $\log 99=2.00 \mathrm{etc}$. for all $19 \mathrm{classes.4)}$. Arrange data in ascending numerical order. Determine number of values within each class interval. Assume that first class interval (0-49 ppb) contained 38 samples; and the second class interval (50-99 ppb) contained 24 samples. 5). Relative frequency of interval no. 1: $38 / 90=.422$. Relative frequency of interval no. $2: 24 / 90=.267 .6$ ) Construct cumulative frequency table by summing relative frequency values; $.422, .422+$ $.267=.689$, etc. Plot relative frequency against cumulative frequency. 7 ). Note where break in slope occurs.

For those cases where the data were sparce and the values were clustered near the lower detection limit of the instrument with a few high values at the opposite extreme, a more empirical method was used. This method called for arranging the data in ascending numerical order then inspecting the data for any gaps. The anomalous values are differentiated from background values. For the lack of a proper sampling design and computer facilities, the gap between background and the anomaly was chosen subjectively, rather than using a statistical test as recommended by Miesh (1976). When background was determined in this manner, sometimes the anomaly criteria of four times typical background was used to see how it compared development. This effort consisted of a literature search, and geologic mapping.

As a further aid in determining background mercury values, sample localities were chosen within a mile or two of the study area. Care was taken to try to sample on the same parent material as in the study area. It was assumed that there were no extreme regional trends. 


\section{APPENDIX G. RESISTIVITY CALCULATIONS}

Table 5. LINE A

COLORADO GEOLOGICAL SURVEY

Geophysical Exploration

(Resistivity Survey)

\begin{tabular}{|c|c|c|c|c|c|c|c|}
\hline \multicolumn{3}{|c|}{$\begin{array}{l}\text { LOCATION } \\
\text { Shaw Springs } \\
\text { CHIEF OPERATOR } \\
\text { Jay Jones }\end{array}$} & \multicolumn{2}{|c|}{$\begin{array}{c}\frac{\text { PROJECT }}{\text { Line A }} \\
\text { FaSSISTANTS } \\
\text { Fargo and Treska }\end{array}$} & Dipol & $\begin{array}{l}\text { DATE } \\
\text { June } \\
\text { METHO } \\
\text { Dipole }\end{array}$ & $\left.\times 100^{\prime}\right)$ \\
\hline Sta. & Range & MA & Voltage & $v_{P}$ & $\mathrm{DV} / \mathrm{I}$ & G.F. & $\mathrm{Pa}_{\mathrm{a}}$ \\
\hline $\begin{array}{l}34-33 \\
32-31 \\
31-30 \\
30-29 \\
29-28 \\
28-27\end{array}$ & $\begin{array}{r}10 \\
1 \\
1 \\
1 \\
1\end{array}$ & $\begin{array}{l}.01 \\
.01 \\
.01 \\
.001 \\
.001\end{array}$ & $\begin{array}{l}66 \\
66 \\
66 \\
66 \\
66\end{array}$ & $\begin{array}{l}1.29 \\
1.18 \\
0.28 \\
1.25 \\
0.71\end{array}$ & $\begin{array}{l}.129 \\
.0118 \\
.00258 \\
.00125 \\
.00071\end{array}$ & $\begin{array}{r}575 \\
2299 \\
5747 \\
11493 \\
20112\end{array}$ & $\begin{array}{l}74.2 \\
27.1 \\
15 \\
14 \\
14\end{array}$ \\
\hline $\begin{array}{l}33-32 \\
31-30 \\
30-29 \\
29-28 \\
28-27 \\
27-26\end{array}$ & $\begin{array}{r}100 \\
10 \\
1 \\
1 \\
1\end{array}$ & $\begin{array}{l}.001 \\
.001 \\
.001 \\
.001 \\
.001\end{array}$ & $\begin{array}{l}66 \\
66 \\
66 \\
66 \\
66\end{array}$ & $\begin{array}{l}2.06 \\
1.73 \\
3.95 \\
1.53 \\
0.78\end{array}$ & $\begin{array}{l}.206 \\
.0173 \\
.00395 \\
.00153 \\
.00078\end{array}$ & $\begin{array}{r}575 \\
2299 \\
5747 \\
11493 \\
20112\end{array}$ & $\begin{array}{r}118 \\
40 \\
23 \\
18 \\
16\end{array}$ \\
\hline $\begin{array}{r}32-31 \\
30-29 \\
29-28 \\
28-27 \\
27-26 \\
26-25 \\
25-24\end{array}$ & $\begin{array}{r}100 \\
10 \\
1 \\
1 \\
1 \\
1\end{array}$ & $\begin{array}{l}.001 \\
.001 \\
.001 \\
.001 \\
.001 \\
.001\end{array}$ & $\begin{array}{l}66 \\
66 \\
66 \\
66\end{array}$ & $\begin{array}{l}3.85 \\
3.58 \\
3.73 \\
1.46 \\
0.65 \\
.55\end{array}$ & $\begin{array}{l}.385 \\
.0358 \\
.00373 \\
.00146 \\
.00065\end{array}$ & $\begin{array}{r}575 \\
2299 \\
5747 \\
11493 \\
20112\end{array}$ & $\begin{array}{r}221 \\
82 \\
21 \\
17 \\
13 \\
18\end{array}$ \\
\hline $\begin{array}{l}31-30 \\
29-28 \\
28-27 \\
27-26 \\
26-25 \\
25-24\end{array}$ & $\begin{array}{r}100 \\
10 \\
1 \\
1 \\
1\end{array}$ & $\begin{array}{l}.001 \\
.001 \\
.001 \\
.001 \\
.001\end{array}$ & $\begin{array}{l}66 \\
66 \\
66 \\
66 \\
66\end{array}$ & $\begin{array}{l}3.35 \\
1.16 \\
3.14 \\
1.22 \\
0.93\end{array}$ & $\begin{array}{l}.335 \\
.0116 \\
.00314 \\
.00122 \\
.00093\end{array}$ & $\begin{array}{r}575 \\
2299 \\
5747 \\
11493 \\
20113\end{array}$ & $\begin{array}{r}193 \\
27 \\
18 \\
14 \\
19\end{array}$ \\
\hline $\begin{array}{l}30-29 \\
28-27 \\
27-26 \\
26-25 \\
25-24 \\
24-23\end{array}$ & $\begin{array}{r}100 \\
10 \\
1 \\
1 \\
1\end{array}$ & $\begin{array}{l}.001 \\
.001 \\
.001 \\
.001 \\
.001\end{array}$ & $\begin{array}{l}66 \\
66 \\
66 \\
66 \\
66\end{array}$ & $\begin{array}{l}1.21 \\
1.00 \\
2.81 \\
1.88 \\
.8430\end{array}$ & $\begin{array}{l}.121 \\
.01 \\
.00281 \\
.00188 \\
.000843\end{array}$ & $\begin{array}{r}575 \\
2299 \\
5747 \\
11493 \\
20113\end{array}$ & $\begin{array}{l}70 \\
23 \\
16 \\
22 \\
17\end{array}$ \\
\hline
\end{tabular}


TABLE 5. LINE A (CONT.)

\begin{tabular}{|c|c|c|c|c|c|c|c|}
\hline Sta. & Range & MA & Voltage & $v_{p}$ & $D V / I$ & $G \cdot F$. & $\mathrm{Pa}$ \\
\hline $29-28$ & & & & & & & \\
\hline $\begin{array}{l}27-26 \\
26-25 \\
25-24 \\
24-23 \\
23-22\end{array}$ & $\begin{array}{r}100 \\
10 \\
10 \\
1 \\
1\end{array}$ & $\begin{array}{l}.001 \\
.001 \\
.001 \\
.001 \\
.001\end{array}$ & $\begin{array}{r}100 \\
100 \\
100 \\
100 \\
66\end{array}$ & $\begin{array}{l}.85 \\
.84 \\
.45 \\
1.61 \\
.78\end{array}$ & $\begin{array}{l}.085 \\
.0084 \\
.0045 \\
.00161 \\
.0078\end{array}$ & $\begin{array}{r}575 \\
2299 \\
5747 \\
11493 \\
20113\end{array}$ & $\begin{array}{l}59 \\
19 \\
26 \\
19 \\
16\end{array}$ \\
\hline $\begin{array}{l}28-27 \\
26-25 \\
25-24 \\
24-23 \\
23-22 \\
22-21\end{array}$ & $\begin{array}{r}100 \\
10 \\
1 \\
1 \\
1\end{array}$ & $\begin{array}{l}.001 \\
.001 \\
.001 \\
.001 \\
.001\end{array}$ & $\begin{array}{l}100 \\
100 \\
100 \\
100 \\
100\end{array}$ & $\begin{array}{r}.46 \\
1.32 \\
3.29 \\
1.35 \\
.67\end{array}$ & $\begin{array}{l}.046 \\
.0132 \\
.00329 \\
.00135 \\
.00067\end{array}$ & $\begin{array}{r}575 \\
2299 \\
5747 \\
11493 \\
20113\end{array}$ & $\begin{array}{l}26 \\
30 \\
19 \\
16 \\
13\end{array}$ \\
\hline $\begin{array}{l}27-26 \\
24-25 \\
25-24 \\
23-22 \\
22-21 \\
21-20 \\
20-19\end{array}$ & $\begin{array}{r}100 \\
10 \\
1 \\
1 \\
1 \\
1\end{array}$ & $\begin{array}{l}.001 \\
.001 \\
.001 \\
.001 \\
.001 \\
.001\end{array}$ & $\begin{array}{l}66 \\
66 \\
66 \\
66 \\
66 \\
66\end{array}$ & $\begin{array}{r}1.60 \\
1.09 \\
3.06 \\
1.26 \\
.72 \\
.51\end{array}$ & $\begin{array}{l}.0109 \\
.00306 \\
.00126 \\
.00072 \\
.00051\end{array}$ & $\begin{array}{r}575 \\
2299 \\
5747 \\
11493 \\
20113\end{array}$ & $\begin{array}{r}6 \\
7 \\
7 \\
8 \\
10\end{array}$ \\
\hline $\begin{array}{l}26-25 \\
24-22 \\
23-22 \\
22-21 \\
21-20 \\
20-19\end{array}$ & $\begin{array}{r}100 \\
10 \\
1 \\
1 \\
1\end{array}$ & $\begin{array}{l}.001 \\
.001 \\
.001 \\
.001 \\
.001\end{array}$ & $\begin{array}{l}66 \\
66 \\
66 \\
66 \\
66\end{array}$ & $\begin{array}{l}.56 \\
.69 \\
2.08 \\
1.02 \\
.64\end{array}$ & $\begin{array}{l}.056 \\
.0069 \\
.00208 \\
.00102 \\
.00064\end{array}$ & $\begin{array}{r}575 \\
2299 \\
5747 \\
11493 \\
20113\end{array}$ & $\begin{array}{l}32 \\
16 \\
12 \\
12 \\
13\end{array}$ \\
\hline $\begin{array}{c}25-24 \\
23-22\end{array}$ & 10 & .001 & & 6.45 & .0645 & & (37) \\
\hline $\begin{array}{l}22-21 \\
21-20 \\
20-19 \\
19-18\end{array}$ & $\begin{array}{r}10 \\
1 \\
1 \\
1\end{array}$ & $\begin{array}{l}.001 \\
.001 \\
.001 \\
.001\end{array}$ & $\begin{array}{l}66 \\
66 \\
66 \\
66\end{array}$ & $\begin{array}{l}1.05 \\
3.48 \\
1.69 \\
1.40\end{array}$ & $\begin{array}{l}.0105 \\
.00348 \\
.00169 \\
.0014\end{array}$ & 11493 & $\begin{array}{l}12 \\
20 \\
19 \\
28\end{array}$ \\
\hline $\begin{array}{r}24-23 \\
22-21 \\
21-20 \\
20-19 \\
19-18 \\
18-17\end{array}$ & $\begin{array}{r}100 \\
10 \\
10 \\
1 \\
1\end{array}$ & $\begin{array}{l}.001 \\
.001 \\
.001 \\
.001 \\
.001\end{array}$ & $\begin{array}{l}66 \\
66 \\
66 \\
66 \\
66\end{array}$ & $\begin{array}{l}1.82 \\
3.36 \\
1.00 \\
3.88 \\
1.50\end{array}$ & $\begin{array}{l}.182 \\
.0336 \\
.010 \\
.00388 \\
.0015\end{array}$ & $\begin{array}{r}575 \\
2299 \\
5747 \\
11493 \\
20113\end{array}$ & $\begin{array}{r}105 \\
77 \\
575 \\
45 \\
30\end{array}$ \\
\hline
\end{tabular}


TABLE 5. LINE A (CONT.)

\begin{tabular}{|c|c|c|c|c|c|c|c|}
\hline Sta. & Range & MA & Voltage & $v_{p}$ & $D V / I$ & G.F. & $\mathrm{Pa}$ \\
\hline $23-22$ & & & & & & & \\
\hline $21-20$ & 100 & .001 & 66 & 1.63 & & & 94 \\
\hline $20-19$ & 10 & .001 & 66 & 3.80 & .038 & 2299 & 87 \\
\hline $19-18$ & 10 & .001 & 66 & 1.22 & .0122 & & 70 \\
\hline $18-17$ & 1 & .001 & 66 & 3.20 & .00320 & & 37 \\
\hline $17-16$ & 1 & .001 & 66 & 1.56 & .00156 & & 32 \\
\hline $22-21$ & & & & & & & \\
\hline $20-19$ & 100 & .001 & 66 & 1.13 & .113 & 575 & 75 \\
\hline $19-18$ & 10 & .001 & 66 & 2.92 & .0292 & 2299 & 67 \\
\hline $18-17$ & 1 & .001 & & 5.66 & .00566 & 5747 & 33 \\
\hline $17-16$ & 1 & .001 & & 2.12 & .00212 & 11493 & 24 \\
\hline $16-15$ & 1 & .001 & & 0.88 & .00088 & 20113 & 18 \\
\hline $21-20$ & & & & & & & \\
\hline $19-18$ & 100 & .001 & 66 & 1.35 & & 575 & 78 \\
\hline $18-17$ & 10 & .001 & 66 & 1.84 & 0.184 & 2299 & 42 \\
\hline $17-16$ & 1 & .001 & 66 & 4.5 & .0045 & 5747 & 26 \\
\hline $16-15$ & 1 & .001 & 66 & 1.56 & 00.156 & & 18 \\
\hline $15-14$ & 1 & .001 & 66 & 0.78 & & & 16 \\
\hline $20-19$ & & & & & & & \\
\hline $18-17$ & 100 & .001 & 66 & 1.21 & .121 & & 70 \\
\hline $17-16$ & 10 & .001 & 66 & 1.67 & .0167 & & 38 \\
\hline $16-15$ & 1 & .001 & 66 & 3.64 & .00364 & & 21 \\
\hline $15-14$ & 1 & .001 & 66 & 1.51 & .00151 & & 17 \\
\hline $14-13$ & 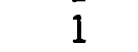 & .001 & 66 & 0.68 & .00068 & & 14 \\
\hline
\end{tabular}

LEGEND: Range $=$ Gain

MA = Dummy TX Current Switch

$V_{p}=$ Balance Control to Null Meter

G.F. = Geometric Factor

$\mathrm{Pa} \quad=$ Apparent Resistivity 
TABLE 6. LINE B.

COLORADO GEOLOGICAL SURVEY

Geophysical Exploration

(Resistivity Survey)

LOCATION

Shaw Springs

CHIEF OPERATOR

Jay Jones $\frac{\text { PROJECT }}{\text { ine B }}$

ASSISTANTS

Fargo and Treska
DATE

1 JuTy 1980

METHOD

Dipole-Dipole (Nx100')

Sta.

Range MA Voltage

$v_{P}$

\section{DV / I}

G.F.

$\mathrm{P}_{\mathrm{a}}$

$2-3$

$4-5$

$5-6$

$6-7$

$7-8$

$8-9$

$3-4$

$5-6$

$6-7$

$7-8$

$7-8$

9-10

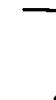

$.01 \quad 100$

.01

100

.01

100

.001

500

.001

500

.01

66

.01

66

$.01 \quad 66$

$.001 \quad 366$

.001

366

4-5

$6-7$

7-8

8-9

9-10

10-11

.01

66

.01

66

.01

66

$.001 \quad 166$

$.001 \quad 166$

7.50

1.15

.38

1.63

.69

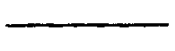

.075

.0115

.0038

.00163

.00069

7.20

1.16

.072

.0116

.0040

.40
.41

.00141

.0007

L.F.

.70

862

3448

8620

17240

30170

65

41

33

28

21

5-6

7-8

8-9

.01

66

.01

66

7.70

.077

.0162

.47

.0047

862

3448

8620

17240

30170

62

40

35

24

21

9-10

.01

66

2.09

.00209

.0018

862

3448

66

55

1.18

41

35

54

10-11

.001

275

275

7.54

1.37

0.0754

.0137

862

65

0.49

.0049

3448

.00241

8620

17240

2.41

.00112

30170

48

42

41

30

6-7

$\begin{array}{cllrrrrr}6-7 & & & & & & & \\ 9-10 & 1 & .01 & 66 & 6.00 & .060 & 862 & 52 \\ 10-11 & 1 & .01 & 66 & 1.48 & .0148 & 3448 & 52 \\ 11-12 & 1 & .01 & 66 & .59 & .0059 & 8620 & 45 \\ 12-13 & 1 & .001 & 300 & 2.44 & .00244 & 17240 & 41 \\ & 1 & .001 & 300 & 1.20 & .00120 & 30170 & 30\end{array}$


TABLE 6. LINE B (CONT.)

\begin{tabular}{|c|c|c|c|c|c|c|c|}
\hline Sta. & Range & MA & Voltage & $v_{p}$ & $\mathrm{DV} / \mathrm{I}$ & G.F. & $\mathrm{P}_{\mathrm{a}}$ \\
\hline $\begin{array}{r}7-8 \\
9-10 \\
10-11 \\
11-12 \\
12-13 \\
13-14\end{array}$ & $\begin{array}{l}1 \\
1 \\
1 \\
1 \\
1\end{array}$ & $\begin{array}{l}.01 \\
.01 \\
.001 \\
.001 \\
.001\end{array}$ & $\begin{array}{r}66 \\
66 \\
166 \\
166 \\
166\end{array}$ & $\begin{array}{l}4.34 \\
1.15 \\
4.33 \\
1.92 \\
1.03\end{array}$ & $\begin{array}{l}.0434 \\
.0115 \\
.00433 \\
.00192 \\
.001\end{array}$ & $\begin{array}{r}862 \\
3448 \\
8620 \\
17240 \\
30170\end{array}$ & $\begin{array}{l}37 \\
40 \\
37 \\
33 \\
30\end{array}$ \\
\hline $\begin{array}{l}8-9 \\
10-11 \\
11-12 \\
12-13 \\
13-14 \\
14-15\end{array}$ & $\begin{array}{l}1 \\
1 \\
1 \\
1 \\
1\end{array}$ & $\begin{array}{l}.01 \\
.01 \\
.01 \\
.001 \\
.001\end{array}$ & $\begin{array}{r}66 \\
66 \\
66 \\
133 \\
133\end{array}$ & $\begin{array}{l}3.40 \\
0.65 \\
0.27 \\
1.20 \\
0.72\end{array}$ & $\begin{array}{l}0.034 \\
0.0065 \\
0.0027 \\
0.00120 \\
0.00072\end{array}$ & $\begin{array}{r}862 \\
3448 \\
8620 \\
17240 \\
30170\end{array}$ & $\begin{array}{l}29 \\
22 \\
23 \\
21 \\
21\end{array}$ \\
\hline $\begin{array}{l}9-10 \\
11-12 \\
12-13 \\
13-14 \\
14-15 \\
15-16\end{array}$ & $\begin{array}{l}1 \\
1 \\
1 \\
1 \\
1\end{array}$ & $\begin{array}{l}.01 \\
.001 \\
.001 \\
.001 \\
.001\end{array}$ & $\begin{array}{r}66 \\
133 \\
133 \\
133 \\
133\end{array}$ & $\begin{array}{l}2.39 \\
4.90 \\
1.95 \\
1.05 \\
0.61\end{array}$ & $\begin{array}{l}0.0239 \\
0.0049 \\
0.00195 \\
0.00105 \\
0.00061\end{array}$ & $\begin{array}{r}862 \\
3448 \\
8620 \\
17240 \\
30170\end{array}$ & $\begin{array}{l}21 \\
17 \\
17 \\
17 \\
18\end{array}$ \\
\hline
\end{tabular}

$10-11$

$\begin{array}{rrrrrlrr}12-13 & 1 & .01 & 66 & 2.45 & 0.0245 & 862 & 21 \\ 13-14 & 1 & .01 & 66 & 0.55 & 0.0055 & 3448 & 17 \\ 14-15 & 1 & .001 & 133 & 2.15 & 0.00215 & 8620 & 17 \\ 15-16 & 1 & .001 & 133 & 1.10 & 0.00110 & 17240 & 17 \\ 16-17 & 1 & .001 & 133 & 0.80 & 0.00080 & 30170 & 24 \\ 8-9 & & & & & & & \\ 10-11 & 1 & .01 & 66 & 3.40 & 0.034 & 862 & 29 \\ 11-12 & 1 & .01 & 66 & 0.65 & 0.0065 & 3448 & 22 \\ 12-13 & 1 & .01 & 66 & 0.27 & 0.0027 & 8620 & 23 \\ 13-14 & 1 & .001 & 133 & 1.20 & 0.00120 & 17240 & 21 \\ 14-15 & 1 & .001 & 133 & 0.72 & 0.00072 & 30170 & 21\end{array}$

9-10

$\begin{array}{rrrrrrrr}11-12 & 1 & .01 & 66 & 2.39 & 0.0239 & 862 & 21 \\ 12-13 & 1 & .001 & 133 & 4.90 & 0.0049 & 3448 & 17 \\ 13-14 & 1 & .001 & 133 & 1.95 & 0.00195 & 8620 & 17 \\ 14-15 & 1 & .001 & 133 & 1.05 & 0.00105 & 17240 & 17 \\ 15-16 & 1 & .001 & 133 & 0.61 & 0.00061 & 30170 & 18 \\ 10-11 & & & & & & & \\ 12-13 & 1 & .01 & 66 & 2.45 & 0.0245 & 862 & 21 \\ 13-14 & 1 & .01 & 66 & 0.55 & 0.0055 & 3448 & 17 \\ 14-15 & 1 & .001 & 133 & 2.15 & 0.00215 & 8620 & 19 \\ 15-16 & 1 & .001 & 133 & 1.10 & 0.00110 & 17240 & 17 \\ 16-17 & 1 & .001 & 133 & 0.80 & 0.00080 & 30170 & 24\end{array}$


TABLE 6. LINE B (CONT.)

\begin{tabular}{|c|c|c|c|c|c|c|c|}
\hline Sta. & Range. & MA & Vol tage & $v_{p}$ & $\mathrm{DV} / \mathrm{I}$ & G.F. & $\mathrm{Pa}$ \\
\hline $\begin{array}{c}11-12 \\
13-14 \\
14-15 \\
15-16 \\
16-17 \\
17-18\end{array}$ & $\begin{array}{l}1 \\
1 \\
1 \\
1 \\
1\end{array}$ & $\begin{array}{l}.01 \\
.001 \\
.001 \\
.001 \\
.001\end{array}$ & $\begin{array}{r}66 \\
133 \\
133 \\
133 \\
133\end{array}$ & $\begin{array}{l}2.11 \\
4.85 \\
1.85 \\
1.10 \\
0.75\end{array}$ & $\begin{array}{l}0.0211 \\
0.00485 \\
0.00185 \\
0.00110 \\
0.00075\end{array}$ & $\begin{array}{r}862 \\
3448 \\
8620 \\
17240 \\
30170\end{array}$ & $\begin{array}{l}18 \\
17 \\
16 \\
17 \\
22\end{array}$ \\
\hline $\begin{array}{l}12-13 \\
14-15 \\
15-16 \\
16-17 \\
17-18\end{array}$ & $\begin{array}{l}1 \\
1 \\
1 \\
1\end{array}$ & $\begin{array}{l}.01 \\
.01 \\
.001 \\
.001\end{array}$ & $\begin{array}{r}66 \\
66 \\
100 \\
100\end{array}$ & $\begin{array}{l}2.25 \\
0.47 \\
2.09 \\
1.20\end{array}$ & $\begin{array}{l}0.0225 \\
0.0047 \\
0.00209 \\
0.00120\end{array}$ & $\begin{array}{r}862 \\
3448 \\
8620 \\
17240\end{array}$ & $\begin{array}{l}19 \\
17 \\
17 \\
17\end{array}$ \\
\hline
\end{tabular}

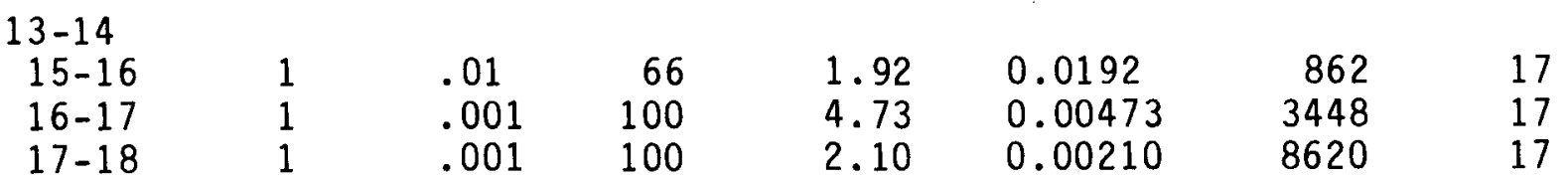

\begin{tabular}{|c|c|c|c|c|c|c|c|}
\hline $14-15$ & & & & & & & \\
\hline $16-17$ & 1 & .01 & $\begin{array}{r}6 \\
66\end{array}$ & $\begin{array}{l}2.00 \\
0.54\end{array}$ & $\begin{array}{l}0.02 \\
0.0054\end{array}$ & $\begin{array}{r}862 \\
3448\end{array}$ & $\begin{array}{l}17 \\
17\end{array}$ \\
\hline
\end{tabular}

$\begin{array}{llllllll}15-16 & & & & & & & \\ 17-18 & 1 & .01 & 66 & 2.07 & 0.0207 & 862 & 17\end{array}$

LEGEND: Range = Gain

$$
\begin{array}{ll}
M A & =\text { Dummy TX Current Switch } \\
V_{p} & \text { Balance Control to Null Meter } \\
\text { G.F. } & \text { Geometric Factor } \\
\mathrm{Pa} & \text { Apparent Resistivity }
\end{array}
$$


TABLE 7. LINE C.

COLORADO GEOLOGICAL SURVEY

Geophysical Exploration

(Resistivity Survey)

LOCATION

Shaw Springs

CHIEF OPERATOR Jay Jones
PROJECT

ASSISTANTS
$1 \mathrm{~J} \frac{\mathrm{DATE}}{\mathrm{UTy} 1980}$

METHOD

Fargo and Treska

Dipole-Dipole $\left(\mathrm{N} \times 100^{\prime}\right)$

\section{$1-2$}

Sta.

$3-4$

$4-5$

$5-6$

$6-7$

$7-8$

$2-3$

$4-5$

$5-6$

$6-7$

$7-8$

8-9

$3-4$

$5-6$

$6-7$

$7-8$

8-9

9-10

4-5

$6-7$

7-8

8-9

9-10

10-11

5-6

7-8

8-9

9-10

10-11

11-12

\section{Range}

MA

\begin{abstract}
Vol tage
\end{abstract}
$V_{P}$

DV /I

G.F.

$\mathrm{P}_{\mathrm{a}}$

.01

.01

66

.001

.001

100

100

.001

100

.01

66

.01

66
166

.001

166

.001

166

.01

66

.01

.001

66

.001

66

.001

100

$100 \quad 1.06$

2.55

0.70

3.46

1.58

1.05

0.0255

0.0070

0.00346

0.00158

.00105

2.90

0.92

3.43

1.95

1.16

0.0290

0.0092

0.00343

0.00195

0.00116

$\longrightarrow$



3.33

0.0333

0.0083

3.77

0.00377

0.00204

.00106

862
3448

8620

17240

30170

22

24

30

18

30

2.04
1.06

862
3448
8620
17240
30170

25

31

30

28

30

862
3448
8620
17240
30170

28

28

32

34

38

$\begin{array}{ll}17240 & 34 \\ 30170 & 38\end{array}$

66

100

2.77

7.92

0.0277

3.62

0.00792

0.00362

1.70

0.00170

0.00139

$.001 \quad 100$

1.39

66

2. 88

0.0288

0.83

3.29

0.0083

0.00329

0.00242

2.42

0.00180

$.001 \quad 100$

1.80

$\begin{array}{lr}.01 & 66 \\ .01 & 66 \\ .001 & 100 \\ .001 & 100 \\ .001 & 100\end{array}$

1.80 
TABLE 7. LINE C (CONT.)

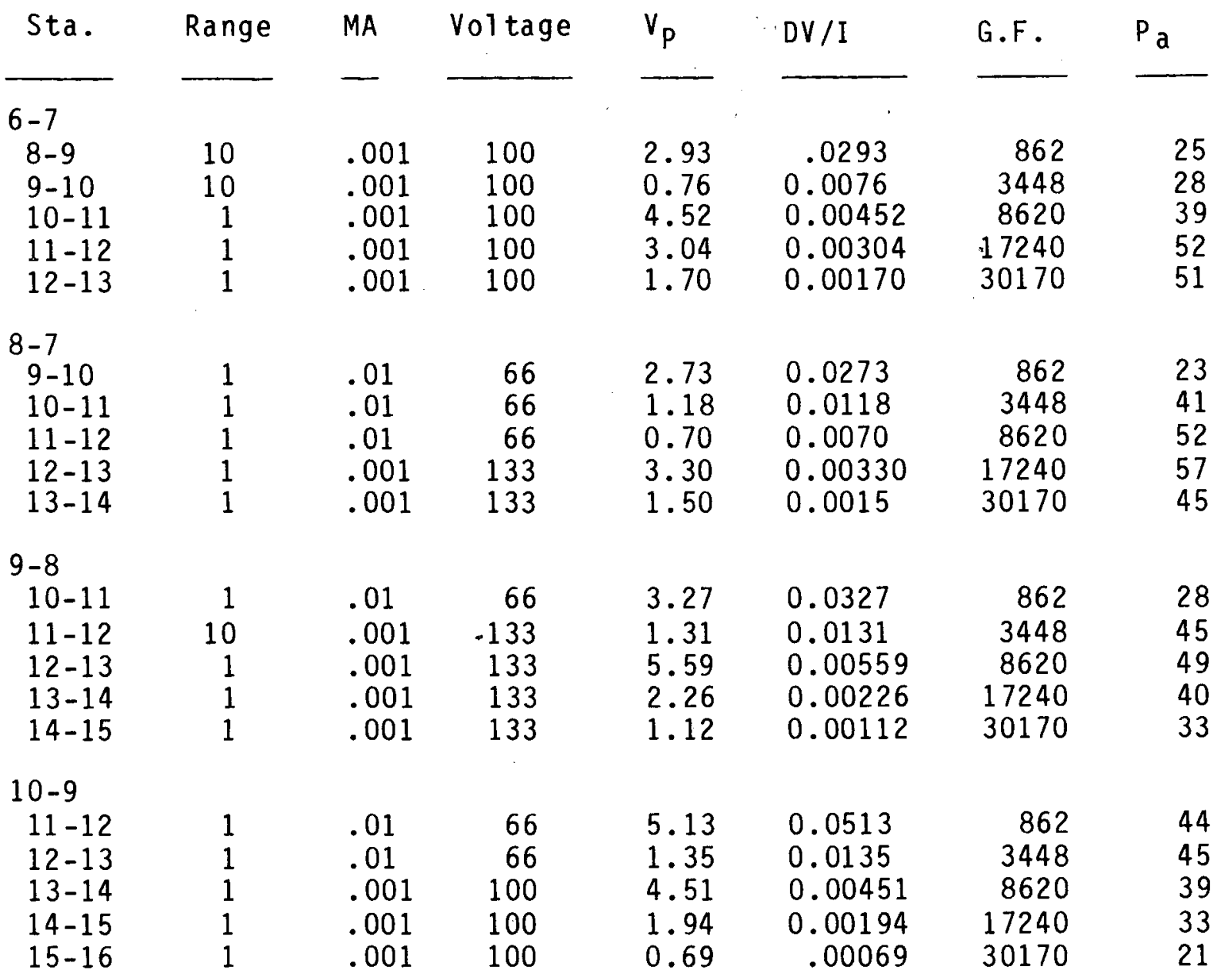

$10-11$

$12-13$

$13-14$

$.01 \quad 100$

7.70

0.770

862

3448

663

$14-15$

$.001 \quad 133$

1.71

0.171

8620

6.10

0.0061

$\begin{array}{ll}0.00176 & 17240 \\ 0.00081 & 30170\end{array}$

$16-17$

$.001 \quad 133$

0.81

59

52

29
24

$11-12$

$13-14$

$14-15$

$15-16$

$16-17$

$17-18$

$.01 \quad 66$

1.00

0.1000

862

86

.01

2.40

0.0240

3448

69

$.01 \quad 6$

0.50

0.0050

8620

1.85

0.00185

17240

43

$\begin{array}{ll}.001 & 200 \\ .001 & 200\end{array}$

0.90

0.00090

30170

27

$12-13$

$14-15$

$15-16$

$16-17$

$17-18$

18-19

$\begin{array}{rrr}10 & .01 & 66 \\ 1 & .01 & 66 \\ 1 & .001 & 133 \\ 1 & .001 & 133 \\ 1 & .001 & 133\end{array}$

1.11
1.62
4.78
1.90
1.01

0.111

862

95

$0.0162 \quad 3448$

55

$0.00478 \quad 8620$

33

29 
TABLE 7. LINE C (CONT.)

\begin{tabular}{|c|c|c|c|c|c|c|c|}
\hline Sta. & Range & MA & Voltage & $v_{p}$ & $\mathrm{DV} / \mathrm{I}$ & G.F. & $\mathrm{P}_{\mathrm{a}}$ \\
\hline $\begin{array}{c}13-14 \\
15-16 \\
16-17 \\
17-18 \\
18-19 \\
19-20\end{array}$ & $\begin{array}{l}1 \\
1 \\
1 \\
1 \\
1\end{array}$ & $\begin{array}{l}.01 \\
.01 \\
.001 \\
.001 \\
.001\end{array}$ & $\begin{array}{r}66 \\
66 \\
166 \\
166 \\
166\end{array}$ & $\begin{array}{l}7.75 \\
1.55 \\
5.00 \\
1.80 \\
0.80\end{array}$ & $\begin{array}{l}0.0775 \\
0.0155 \\
0.0050 \\
0.00180 \\
0.00080\end{array}$ & $\begin{array}{r}862 \\
3448 \\
8620 \\
17240 \\
30170\end{array}$ & $\begin{array}{l}67 \\
52 \\
43 \\
30 \\
24\end{array}$ \\
\hline $\begin{array}{c}14-15 \\
16-17 \\
17-18 \\
18-19 \\
19-20 \\
20-21\end{array}$ & $\begin{array}{l}1 \\
1 \\
1 \\
1 \\
1\end{array}$ & $\begin{array}{l}.01 \\
.001 \\
.001 \\
.001 \\
.001\end{array}$ & $\begin{array}{r}66 \\
200 \\
200 \\
200 \\
225\end{array}$ & $\begin{array}{l}8.50 \\
1.90 \\
5.38 \\
1.70 \\
0.80\end{array}$ & $\begin{array}{c}.0850 \\
0.00190 \\
0.00538 \\
0.00170 \\
0.00080\end{array}$ & $\begin{array}{r}862 \\
3448 \\
8620 \\
17240 \\
30170\end{array}$ & $\begin{array}{l}73 \\
70 \\
41 \\
28 \\
24\end{array}$ \\
\hline $\begin{array}{l}15-16 \\
17-18 \\
18-19 \\
19-20 \\
20-21\end{array}$ & $\begin{array}{l}1 \\
1 \\
1 \\
1\end{array}$ & $\begin{array}{l}.01 \\
.01 \\
.001 \\
.001\end{array}$ & $\begin{array}{r}66 \\
66 \\
100 \\
100\end{array}$ & $\begin{array}{l}9.68 \\
1.89 \\
3.68 \\
1.50\end{array}$ & $\begin{array}{l}.0968 \\
.0189 \\
.00368 \\
.00150\end{array}$ & $\begin{array}{r}862 \\
3448 \\
8620 \\
17240\end{array}$ & $\begin{array}{l}84 \\
65 \\
32 \\
26\end{array}$ \\
\hline $\begin{array}{c}16-17 \\
18-19 \\
19-20 \\
20-21\end{array}$ & $\begin{array}{r}10 \\
10 \\
1\end{array}$ & $\begin{array}{l}.01 \\
.001 \\
.001\end{array}$ & $\begin{array}{r}66 \\
100 \\
100\end{array}$ & $\begin{array}{l}0.93 \\
1.10 \\
2.64\end{array}$ & $\begin{array}{l}0.093 \\
0.0011 \\
0.00264\end{array}$ & $\begin{array}{r}862 \\
3448 \\
8620\end{array}$ & $\begin{array}{l}80 \\
40 \\
23\end{array}$ \\
\hline $\begin{array}{l}17-18 \\
19-20 \\
20-21\end{array}$ & $\begin{array}{l}1 \\
1\end{array}$ & $\begin{array}{l}.01 \\
.01\end{array}$ & $\begin{array}{l}100 \\
100\end{array}$ & $\begin{array}{l}5.50 \\
0.63\end{array}$ & $\begin{array}{l}0.055 \\
0.0063\end{array}$ & $\begin{array}{r}862 \\
3448\end{array}$ & $\begin{array}{l}47 \\
22\end{array}$ \\
\hline $\begin{array}{c}18-19 \\
20-21\end{array}$ & 1 & .01 & 66 & 2.90 & 0.029 & 862 & 25 \\
\hline
\end{tabular}

LEGEND: Range $=$ Gain

MA = Dummy TX Current Switch

$V_{p}=$ Balance Control to Null Meter

G.F. = Geometric Factor

$\mathrm{Pa}=$ Apparent Resistivity 
TABLE 8. LINE D.

COLORADO GEOLOGICAL SURVEY

Geophysical Exploration

(Resistivity Survey)

\begin{tabular}{|c|c|c|c|c|c|c|c|}
\hline \multicolumn{3}{|c|}{$\begin{array}{l}\text { LOCATION } \\
\text { Shaw Springs } \\
\text { CHIEF OPERATOR } \\
\text { Jay Jones } \\
\end{array}$} & \multicolumn{2}{|c|}{$\begin{array}{c}\text { PROJECT } \\
\text { Line D } \\
\text { ASSISTANTS } \\
\text { Fargo and Treska } \\
\end{array}$} & \multicolumn{3}{|c|}{ 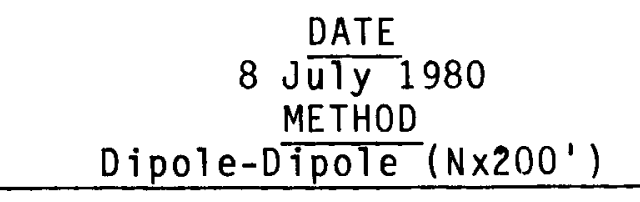 } \\
\hline Sta. & Range & MA & Voltage & $v_{p}$ & $\mathrm{DV} / \mathrm{I}$ & G.F. & $\mathrm{Pa}$ \\
\hline $\begin{array}{c}44-42 \\
38-40 \\
38-36 \\
36-34 \\
34-32 \\
32-30\end{array}$ & $\begin{array}{r}100 \\
1 \\
1 \\
1 \\
-\end{array}$ & $\begin{array}{l}.001 \\
.001 \\
.001 \\
.001 \\
.001\end{array}$ & $\begin{array}{l}133 \\
133 \\
133 \\
133 \\
133\end{array}$ & $\begin{array}{r}1.06 \\
1.26 \\
5.20 \\
1.75 \\
\text { N.R. - - 10st s }\end{array}$ & $\begin{array}{l}0.106 \\
0.00126 \\
0.0052 \\
0.00175 \\
\text { signal }\end{array}$ & $\begin{array}{r}1149 \\
4597 \\
11493 \\
22987 \\
40227\end{array}$ & $\begin{array}{l}121.8 \\
5.8 \\
59 \\
40.2\end{array}$ \\
\hline $\begin{array}{r}42-40 \\
38-36 \\
36-34 \\
34-32 \\
32-30 \\
30-28\end{array}$ & $\begin{array}{r}10 \\
10 \\
1 \\
1 \\
1\end{array}$ & $\begin{array}{l}.001 \\
.001 \\
.001 \\
.001 \\
.001\end{array}$ & $\begin{array}{l}133 \\
133 \\
133 \\
133 \\
133\end{array}$ & $\begin{array}{l}7.91 \\
1.59 \\
4.30 \\
1.72 \\
0.65\end{array}$ & $\begin{array}{l}0.00791 \\
0.00159 \\
0.00430 \\
0.00172 \\
0.00065\end{array}$ & $\begin{array}{l}1149 \\
4597 \\
11493 \\
22987 \\
40227\end{array}$ & $\begin{array}{l}91 \\
73 \\
49.4 \\
39.5 \\
26.15\end{array}$ \\
\hline $\begin{array}{c}40-38 \\
36-34 \\
34-32 \\
32-30 \\
30-28 \\
28-26\end{array}$ & $\begin{array}{r}10 \\
10 \\
1 \\
1 \\
-\end{array}$ & $\begin{array}{l}.001 \\
.001 \\
.001 \\
.001 \\
.001\end{array}$ & $\begin{array}{l}133 \\
133 \\
133 \\
133 \\
133\end{array}$ & $\begin{array}{l}7.40 \\
1.54 \\
4.90 \\
1.50 \\
\text { N.R.--10st }\end{array}$ & $\begin{array}{l}0.0074 \\
0.0154 \\
0.00490 \\
0.00150 \\
\text { t signal -- }\end{array}$ & $\begin{array}{l}1149 \\
4597 \\
11493 \\
22987 \\
20112\end{array}$ & $\begin{array}{l}85.1 \\
70.8 \\
56.3 \\
34.5\end{array}$ \\
\hline $\begin{array}{c}38-36 \\
34-32 \\
32-30 \\
30-28 \\
28-26 \\
26-24\end{array}$ & $\begin{array}{r}10 \\
1 \\
1 \\
1 \\
1\end{array}$ & $\begin{array}{l}.001 \\
.001 \\
.001 \\
.001 \\
.001\end{array}$ & $\begin{array}{l}225 \\
225 \\
166 \\
166 \\
166\end{array}$ & $\begin{array}{l}3.53 \\
8.90 \\
2.45 \\
0.91 \\
0.39\end{array}$ & $\begin{array}{l}0.0353 \\
0.0089 \\
0.00245 \\
0.00091 \\
0.00039\end{array}$ & $\begin{array}{r}11492 \\
4597 \\
11493 \\
22987 \\
40227\end{array}$ & $\begin{array}{l}40.6 \\
41.0 \\
28.1 \\
21.0 \\
15.7\end{array}$ \\
\hline $\begin{array}{l}36-34 \\
32-30 \\
28-30 \\
28-26 \\
26-24\end{array}$ & $\begin{array}{r}10 \\
10 \\
1 \\
1\end{array}$ & $\begin{array}{l}.001 \\
.001 \\
.001 \\
.001\end{array}$ & $\begin{array}{l}166 \\
166 \\
166 \\
166\end{array}$ & $\begin{array}{l}5.02 \\
1.00 \\
2.80 \\
0.94\end{array}$ & $\begin{array}{l}0.0502 \\
0.010 \\
0.0280 \\
0.00094\end{array}$ & $\begin{array}{r}11492 \\
4597 \\
11493 \\
22987\end{array}$ & $\begin{array}{r}57.7 \\
46.0 \\
321.8 \\
21.6\end{array}$ \\
\hline 26 & - & .001 & 166 & & gnal-- & 40227 & \\
\hline
\end{tabular}


TABLE 8. LINE D (CONT.)

\begin{tabular}{|c|c|c|c|c|c|c|c|}
\hline Sta. & Range & MA & Voltage & $v_{p}$ & $\mathrm{DV} / \mathrm{I}$ & G.F. & $\mathrm{Pa}$ \\
\hline \multicolumn{8}{|l|}{$34-32$} \\
\hline $30-28$ & 10 & .001 & 100 & 7.10 & 0.0710 & 11492 & 81.6 \\
\hline $28-26$ & 10 & .001 & 100 & 1.40 & 0.0140 & 4597 & 64.4 \\
\hline $26-24$ & 10 & .001 & 100 & 0.40 & 0.0040 & 11493 & 45.9 \\
\hline $24-22$ & 1 & .001 & 100 & 1.14 & 0.00114 & 22987 & 26.2 \\
\hline $22-20$ & 1 & .001 & 100 & 0.40 & 0.00040 & 40227 & 16.1 \\
\hline \multicolumn{8}{|l|}{$32-30$} \\
\hline $28-26$ & 100 & .001 & 100 & 1.05 & 0.105 & 11497 & 120.7 \\
\hline $26-24$ & 10 & .001 & 100 & 2.20 & 0.022 & 4597 & 101.1 \\
\hline $24-22$ & 10 & .001 & 100 & 0.35 & 0.0035 & 11493 & 40.2 \\
\hline $22-20$ & 1 & .001 & 100 & N.R. - - Lost & Signal-- & 22987 & \\
\hline \multicolumn{8}{|l|}{$28-30$} \\
\hline $26-24$ & 100 & .001 & 100 & 0.98 & 0.098 & 11497 & 112.6 \\
\hline $24-22$ & 10 & .001 & 100 & 1.49 & 0.0149 & 4597 & 68.5 \\
\hline $22-20$ & 1 & .001 & 100 & 3.77 & 0.00377 & 11493 & 43.3 \\
\hline $20-18$ & 1 & .001 & 100 & 1.26 & 0.00126 & 22987 & 51.0 \\
\hline $18-16$ & 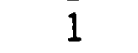 & .001 & 100 & 0.71 & 0.00071 & 40227 & 28.6 \\
\hline
\end{tabular}

$26-28$

$\begin{array}{llll}24-22 & 10 & .01 & 66\end{array}$

$\begin{array}{rrrr}22-20 & 1 & .01 & 66\end{array}$

$\begin{array}{llll}20-18 & 1 & .001 & 166\end{array}$

$\begin{array}{llll}18-16 & 1 & .001 & 166\end{array}$

$\begin{array}{llll}16-14 & 1 & .001 & 166\end{array}$

1.00

1.67

4.05

1.55

0.54

0.100

11497

$\begin{array}{lr}0.0167 & 4597 \\ 0.00405 & 11493\end{array}$

$0.00155 \quad 22987$

$0.00054 \quad 40227$

1114.9

76.77

46.5

35.6

21.7

$24-26$

$20-22$

$8-20$

$16-18$

$14-16$

$12-14$

$10 \quad .01$

.001

66

0.93

0.093

11492

0.0167

4597

4.42

0.00442

11493

$.001 \quad 166$

1.09

0.00109

22987

0.60

0.0006

40227

106.9

76.7

50.8

25.1

24.1

$24-22$

20-18

18-16

16-14

$14-12$

$12-10$

$10 \quad .01$

.001

0.97

0.097

11492

$0.0176 \quad 4597$

111.4

1.76

0.00311

11493

1. 31

$0.00130 \quad 22987$

0.55

$0.00055 \quad 40227$

80.9

36.0

29.9

$.001 \quad 166$

22.1

$22-20$

18-16

16-14

$14-12$

$12-10$

$\begin{array}{rlr}10 & .01 & 66 \\ 10 & .001 & 200 \\ 1 & .001 & 200 \\ 1 & .001 & 166 \\ 1 & .001 & 166\end{array}$

0.88
1.04
3.45
1.17
0.54

0.088

11492

$0.0104 \quad 4597$

101.1

$0.00345 \quad 11493$

$0.00117 \quad 22987$

47.8

39.6

26.9

10-8

$.001 \quad 166$

$.00054 \quad 40227$

21.7 
TABLE 8. LINE D (CONT.)

\begin{tabular}{|c|c|c|c|c|c|c|c|}
\hline Sta. & Range & MA & Voltage & $v_{p}$ & $\mathrm{DV} / \mathrm{I}$ & G.F. & $\mathrm{Pa}$ \\
\hline $\begin{array}{l}20-18 \\
16-14 \\
14-12 \\
12-10 \\
10-8\end{array}$ & $\begin{array}{r}1 \\
10 \\
1 \\
1\end{array}$ & $\begin{array}{l}.01 \\
.001 \\
.001 \\
.001\end{array}$ & $\begin{array}{r}66 \\
166 \\
166 \\
166\end{array}$ & $\begin{array}{l}5.68 \\
1.18 \\
2.70 \\
0.96\end{array}$ & $\begin{array}{l}0.0568 \\
0.0118 \\
0.0027 \\
0.00096\end{array}$ & $\begin{array}{r}11492 \\
4597 \\
11493 \\
22987\end{array}$ & $\begin{array}{l}65.3 \\
54.2 \\
31.0 \\
22.1\end{array}$ \\
\hline $\begin{array}{l}18-16 \\
14-12 \\
12-10 \\
10-8\end{array}$ & $\begin{array}{r}10 \\
10 \\
1\end{array}$ & $\begin{array}{l}.01 \\
.001 \\
.001\end{array}$ & $\begin{array}{r}66 \\
133 \\
133\end{array}$ & $\begin{array}{l}1.05 \\
1.67 \\
4.06\end{array}$ & $\begin{array}{l}0.105 \\
0.0167 \\
0.00406\end{array}$ & $\begin{array}{r}11492 \\
4597 \\
11493\end{array}$ & $\begin{array}{r}120.7 \\
76.7 \\
46.6\end{array}$ \\
\hline $\begin{array}{c}16-14 \\
12-10 \\
10-8\end{array}$ & $\begin{array}{r}100 \\
10\end{array}$ & $\begin{array}{l}.001 \\
.001\end{array}$ & $\begin{array}{l}133 \\
133\end{array}$ & $\begin{array}{l}1.05 \\
1.75\end{array}$ & $\begin{array}{l}0.105 \\
0.0175\end{array}$ & $\begin{array}{r}11492 \\
4597\end{array}$ & $\begin{array}{c}120.6 \\
80.45\end{array}$ \\
\hline $\begin{array}{r}14-12 \\
10-8\end{array}$ & 100 & .001 & 133 & 1.03 & 0.103 & 11492 & 118.4 \\
\hline $\begin{array}{r}50-48 \\
46-44 \\
44-42 \\
42-40 \\
40-38 \\
38-36\end{array}$ & $\begin{array}{r}10 \\
10 \\
1 \\
1\end{array}$ & $\begin{array}{l}.001 \\
.001 \\
.001 \\
.001 \\
.001\end{array}$ & $\begin{array}{l}133 \\
133 \\
133 \\
133 \\
133\end{array}$ & $\begin{array}{r}8.15 \\
1.81 \\
5.38 \\
1.74 \\
-.\end{array}$ & $\begin{array}{l}0.00815 \\
0.0181 \\
0.00538 \\
0.00174 \\
. \text { R. -- }\end{array}$ & $\begin{array}{r}11492 \\
4597 \\
11493 \\
22987 \\
40227\end{array}$ & $\begin{array}{l}93.7 \\
83.2 \\
61.8 \\
39.9\end{array}$ \\
\hline $\begin{array}{r}48-46 \\
44-42 \\
42-40 \\
40-38 \\
38-36 \\
36-34\end{array}$ & $\begin{array}{r}100 \\
10 \\
1 \\
1 \\
1\end{array}$ & $\begin{array}{l}.001 \\
.001 \\
.001 \\
.001 \\
.001\end{array}$ & $\begin{array}{l}200 \\
200 \\
200 \\
200 \\
200\end{array}$ & $\begin{array}{l}1.08 \\
2.38 \\
6.40 \\
1.60 \\
0.75\end{array}$ & $\begin{array}{l}0.108 \\
0.0128 \\
0.0064 \\
0.00160 \\
0.00075\end{array}$ & $\begin{array}{r}11492 \\
4597 \\
11493 \\
22987 \\
40227\end{array}$ & $\begin{array}{c}124.1 \\
109.4 \\
73.5 \\
36.7 \\
30.17\end{array}$ \\
\hline $\begin{array}{c}46-44 \\
42-40 \\
40-38 \\
38-36 \\
36-34 \\
34-32\end{array}$ & $\begin{array}{r}100 \\
10 \\
1 \\
1 \\
1\end{array}$ & $\begin{array}{l}.001 \\
.001 \\
.001 \\
.001 \\
.001\end{array}$ & $\begin{array}{l}200 \\
200 \\
200 \\
200 \\
200\end{array}$ & $\begin{array}{l}1.09 \\
2.35 \\
4.80 \\
1.85 \\
0.78\end{array}$ & $\begin{array}{l}0.109 \\
0.00235 \\
0.0048 \\
0.00185 \\
0.00078\end{array}$ & $\begin{array}{r}11492 \\
4597 \\
11493 \\
22987 \\
40227\end{array}$ & $\begin{array}{r}125.3 \\
108.0 \\
55.1 \\
42.5 \\
31.4\end{array}$ \\
\hline
\end{tabular}

LEGEND: Range = Gain

$$
\begin{array}{ll}
M A & =\text { Dummy TX Current Switch } \\
V_{p} & =\text { Balance Control to Null Meter } \\
G . F & \text { Geometric Factor } \\
\mathrm{Pa} & \text { Apparent Resistivity }
\end{array}
$$


TABLE 9. LINE E

COLORADO GEOLOGICAL SURVEY

Geophysical Exploration

(Resistivity Survey)

LOCATION

Shaw Springs CHIEF OPERATOR Jay Jones
PROJECT

Line E

ASSISTANTS
$9 \frac{\text { DATE }}{\text { JUly } 1980}$

METHOD

Fargo and Treska Dipole-Dipote $\left(\mathrm{N} \times 200^{\prime}\right)$

Sta. Range MA Voltage

--

---.-

$v_{p}$

DV $/ I$

G.F.

-...-

$\mathrm{P}_{\mathrm{a}}$

$1-3$

5-7

7-9

9-11

$11-13$

13-15

$\begin{array}{ll}1 & .01 \\ 1 & .01 \\ 1 & .001\end{array}$

66

6.50

0.0650

1149

4597

133

.001

133

.001

133

1.76

0.010

0.00176

11493

1.18

0.00118

22987

0.45

0.00045

40227

3-5

7-9

9-11

11-13

13-15

15-17

$\begin{array}{rl}100 & .001 \\ 10 & .001 \\ 1 & .001 \\ 1 & .001 \\ 1 & .001\end{array}$

66

1.11

0.111

0.010

1149

$66 \quad 1.00$

0.00245

4597

2.45

0.00104

11493

$66 \quad 1.04$

0.00055

22987

0.55

40227

5-7

9-11

11-13

13-15

15-17

17-19

$\begin{array}{ll}1 & .01 \\ 1 & .01 \\ 1 & .001 \\ 1 & .001 \\ 1 & .001\end{array}$

66

5.50

0.055

0.70

0.0070

2.17

0.00217

0.00091

0.91

0.00041

1149

4597

66

11493

22987

66

40227

7-9

$11-13$

13-15

15-17

17-19

19-21

$\begin{array}{lll}1 & .01 & 66 \\ 1 & .001 & 133 \\ 1 & .001 & 133 \\ 1 & .001 & 133 \\ 1 & .001 & 133\end{array}$

66

133
133

133

6.30

0.0630

8.50

0.00850

11493

4597

2.40

0.00240

11493

1.08

0.00108

22987

0.64

0.00064

40227

127.5

46.0

28.1

24.0

22.12

9-11

$\begin{array}{lllr}13-15 & 1 & .01 & 66 \\ 15-17 & 1 & .001 & 133 \\ 17-19 & 1 & .001 & 133 \\ 19-21 & 1 & .001 & 133 \\ 21-23 & 1 & .001 & 133\end{array}$

3.90

0.0390

11493

4597

11493

1.84

0.00540

22987

0.95

0.00095

0.48

0.00048

40227

63.2

32.18

25.0

20.9

16.5

72.4

39.0

27.6

24.8

25.7

133

40227

44.8
24.8
21.15
21.84
19.3


TABLE 9 LINE E (CONT.)

\begin{tabular}{|c|c|c|c|c|c|c|c|}
\hline Sta. & Range & MA & Voltage & $v_{p}$ & $\mathrm{DV} / \mathrm{I}$ & $G . F$. & $\mathrm{P}_{\mathrm{a}}$ \\
\hline $\begin{array}{l}11-13 \\
15-17 \\
17-19 \\
19-21 \\
21-23 \\
23-25\end{array}$ & $\begin{array}{l}1 \\
1 \\
1 \\
1 \\
1\end{array}$ & $\begin{array}{l}.01 \\
.001 \\
.001 \\
.001 \\
.001\end{array}$ & $\begin{array}{r}66 \\
133 \\
133 \\
133 \\
133\end{array}$ & $\begin{array}{l}3.08 \\
5.08 \\
2.00 \\
0.91 \\
0.50\end{array}$ & $\begin{array}{l}.0308 \\
0.00508 \\
0.0020 \\
0.00091 \\
0.00050\end{array}$ & $\begin{array}{r}11493 \\
4597 \\
11493 \\
22987 \\
40227\end{array}$ & $\begin{array}{l}43.7 \\
23.4 \\
23.0 \\
20.9 \\
20.1\end{array}$ \\
\hline $\begin{array}{l}13-15 \\
17-19 \\
19-21 \\
21-23 \\
23-25 \\
25-27\end{array}$ & $\begin{array}{l}1 \\
1 \\
1 \\
1 \\
1\end{array}$ & $\begin{array}{l}.01 \\
.001 \\
.001 \\
.001 \\
.001\end{array}$ & $\begin{array}{r}66 \\
133 \\
133 \\
133 \\
133\end{array}$ & $\begin{array}{l}2.68 \\
4.56 \\
1.78 \\
0.81 \\
0.45\end{array}$ & $\begin{array}{l}0.0268 \\
0.00456 \\
0.00178 \\
0.00081 \\
0.00045\end{array}$ & $\begin{array}{r}1149 \\
4597 \\
11493 \\
22987 \\
40227\end{array}$ & $\begin{array}{l}31.0 \\
21.0 \\
20.5 \\
18.6 \\
18.10\end{array}$ \\
\hline $\begin{array}{c}15-17 \\
19-21 \\
21-23 \\
23-25 \\
25-27 \\
27-29\end{array}$ & $\begin{array}{r}10 \\
1 \\
1 \\
1 \\
1\end{array}$ & $\begin{array}{l}.001 \\
.001 \\
.001 \\
.001 \\
.001\end{array}$ & $\begin{array}{l}133 \\
133 \\
133 \\
133 \\
133\end{array}$ & $\begin{array}{l}2.90 \\
4.30 \\
1.82 \\
1.00 \\
0.48\end{array}$ & $\begin{array}{l}0.0240 \\
0.00430 \\
0.00182 \\
0.0010 \\
0.00048\end{array}$ & $\begin{array}{r}1149 \\
4597 \\
11493 \\
22987 \\
40227\end{array}$ & $\begin{array}{l}33.3 \\
19.7 \\
20.9 \\
22.9 \\
19.3\end{array}$ \\
\hline $\begin{array}{c}17-19 \\
21-23 \\
23-25 \\
25-27 \\
27-29 \\
29-31\end{array}$ & $\begin{array}{l}1 \\
1 \\
1 \\
1 \\
1\end{array}$ & $\begin{array}{l}.01 \\
.001 \\
.001 \\
.001 \\
.001\end{array}$ & $\begin{array}{r}66 \\
133 \\
133 \\
133 \\
133\end{array}$ & $\begin{array}{l}1.31 \\
3.67 \\
1.78 \\
0.85 \\
0.36\end{array}$ & $\begin{array}{l}0.0131 \\
0.00367 \\
0.00178 \\
0.00085 \\
0.00036\end{array}$ & $\begin{array}{r}1149 \\
4597 \\
11493 \\
22987 \\
40227\end{array}$ & $\begin{array}{l}15.2 \\
16.8 \\
20.45 \\
19.5 \\
14.48\end{array}$ \\
\hline $\begin{array}{c}19-21 \\
25-23 \\
27-25 \\
29-27 \\
31-29 \\
33-31\end{array}$ & $\begin{array}{l}1 \\
1 \\
1 \\
1 \\
1\end{array}$ & $\begin{array}{l}.01 \\
.001 \\
.001 \\
.001 \\
.001\end{array}$ & $\begin{array}{r}66 \\
166 \\
166 \\
166 \\
166\end{array}$ & $\begin{array}{l}1.15 \\
4.32 \\
1.86 \\
0.76 \\
0.30\end{array}$ & $\begin{array}{l}0.0115 \\
0.00432 \\
0.00186 \\
0.00076 \\
0.00030\end{array}$ & $\begin{array}{r}1149 \\
4597 \\
11493 \\
22987 \\
40227\end{array}$ & $\begin{array}{l}13.2 \\
19.8 \\
21.4 \\
17.5 \\
12.06\end{array}$ \\
\hline $\begin{array}{l}21-23 \\
25-27 \\
27-29 \\
29-31 \\
31-33 \\
33-35\end{array}$ & $\begin{array}{l}1 \\
1 \\
1 \\
1 \\
1\end{array}$ & $\begin{array}{l}.01 \\
.001 \\
.001 \\
.001 \\
.001\end{array}$ & $\begin{array}{r}66 \\
250 \\
250 \\
250 \\
250\end{array}$ & $\begin{array}{l}1.22 \\
4.40 \\
1.53 \\
0.54 \\
0.27\end{array}$ & $\begin{array}{l}0.0122 \\
0.00440 \\
0.00153 \\
0.00054 \\
0.00027\end{array}$ & $\begin{array}{r}1149 \\
4597 \\
11493 \\
22987 \\
40227\end{array}$ & $\begin{array}{l}14.0 \\
20.2 \\
17.5 \\
12.4 \\
10.87\end{array}$ \\
\hline $\begin{array}{r}23-25 \\
27-29 \\
29-31 \\
31-33 \\
33-35 \\
35-37\end{array}$ & $\begin{array}{l}1 \\
1 \\
1 \\
1 \\
1\end{array}$ & $\begin{array}{l}.01 \\
.001 \\
.001 \\
.001 \\
.001\end{array}$ & $\begin{array}{r}66 \\
166 \\
166 \\
166 \\
166\end{array}$ & $\begin{array}{l}1.43^{\circ} \\
4.04 \\
1.31 \\
0.65 \\
0.28\end{array}$ & $\begin{array}{l}0.0143 \\
0.00404 \\
0.00131 \\
0.00065 \\
0.00028\end{array}$ & $\begin{array}{r}1149 \\
4597 \\
11493 \\
22987 \\
40227\end{array}$ & $\begin{array}{l}16.4 \\
18.5 \\
15.1 \\
14.94 \\
11.3\end{array}$ \\
\hline
\end{tabular}


TABLE 9. LINE E (CONT.)

\begin{tabular}{|c|c|c|c|c|c|c|c|}
\hline Sta. & Range & MA & Vol tage & $v_{p}$ & $\mathrm{DV} / \mathrm{I}$ & G.F. & $\mathrm{P}_{\mathrm{a}}$ \\
\hline $\begin{array}{r}25-27 \\
29-31 \\
31-33 \\
33-35 \\
35-37 \\
37-39\end{array}$ & $\begin{array}{l}1 \\
1 \\
1 \\
1 \\
1\end{array}$ & $\begin{array}{l}.01 \\
.001 \\
.001 \\
.001 \\
.001\end{array}$ & $\begin{array}{r}66 \\
066 \\
066 \\
066 \\
66\end{array}$ & $\begin{array}{l}1.36 \\
3.52 \\
1.39 \\
0.48 \\
0.27\end{array}$ & $\begin{array}{l}0.0136 \\
0.00352 \\
0.00139 \\
0.00048 \\
.00027\end{array}$ & $\begin{array}{r}1149 \\
4597 \\
11493 \\
22987 \\
40227\end{array}$ & $\begin{array}{l}15.6 \\
16.2 \\
16.0 \\
11.0 \\
10.9\end{array}$ \\
\hline $\begin{array}{r}27-29 \\
31-33 \\
33-35 \\
35-37 \\
37-39 \\
39-41\end{array}$ & $\begin{array}{l}1 \\
1 \\
1 \\
1 \\
1\end{array}$ & $\begin{array}{l}.01 \\
.001 \\
.001 \\
.001 \\
.001\end{array}$ & $\begin{array}{l}66 \\
66 \\
66 \\
66 \\
66\end{array}$ & $\begin{array}{l}1.39 \\
3.58 \\
1.04 \\
0.48 \\
0.24\end{array}$ & $\begin{array}{l}0.0139 \\
0.00358 \\
0.00104 \\
0.00048 \\
0.00024\end{array}$ & $\begin{array}{r}1149 \\
4597 \\
11493 \\
22987 \\
40227\end{array}$ & $\begin{array}{c}16.0 \\
16.5 \\
11.95 \\
11.0 \\
9.6\end{array}$ \\
\hline $\begin{array}{l}29-31 \\
33-35 \\
35-37 \\
37-39 \\
39-41 \\
41-43\end{array}$ & $\begin{array}{l}1 \\
1 \\
1 \\
1 \\
1\end{array}$ & $\begin{array}{l}.01 \\
.001 \\
.001 \\
.001 \\
.001\end{array}$ & $\begin{array}{r}66 \\
100 \\
100 \\
100 \\
100\end{array}$ & $\begin{array}{l}1.49 \\
3.21 \\
0.95 \\
0.38 \\
0.22\end{array}$ & $\begin{array}{l}0.0149 \\
0.00321 \\
0.00095 \\
.00038 \\
.00022\end{array}$ & $\begin{array}{r}1149 \\
4597 \\
11493 \\
22987 \\
40227\end{array}$ & $\begin{array}{c}17.1 \\
14.8 \\
11.0 \\
8.7 \\
8.85\end{array}$ \\
\hline $\begin{array}{r}31-33 \\
35-37 \\
37-39 \\
39-41 \\
41-43 \\
43-45\end{array}$ & $\begin{array}{l}1 \\
1 \\
1 \\
1 \\
1\end{array}$ & $\begin{array}{l}.01 \\
.001 \\
.001 \\
.001 \\
.001\end{array}$ & $\begin{array}{r}66 \\
133 \\
133 \\
133 \\
133\end{array}$ & $\begin{array}{l}2.11 \\
3.41 \\
0.84 \\
0.44 \\
0.20\end{array}$ & $\begin{array}{l}0.0211 \\
0.00341 \\
0.00084 \\
0.00044 \\
0.00020\end{array}$ & $\begin{array}{r}1149 \\
4597 \\
11493 \\
22987 \\
40227\end{array}$ & $\begin{array}{r}24.3 \\
15.7 \\
9.7 \\
10.1 \\
8.0\end{array}$ \\
\hline $\begin{array}{l}33-35 \\
37-39 \\
39-41 \\
41-43 \\
43-45\end{array}$ & $\begin{array}{l}1 \\
1 \\
1 \\
1\end{array}$ & $\begin{array}{l}.01 \\
.001 \\
.001 \\
.001\end{array}$ & $\begin{array}{l}66 \\
66 \\
66 \\
66\end{array}$ & $\begin{array}{l}2.46 \\
2.07 \\
0.77 \\
0.32\end{array}$ & $\begin{array}{l}0.0246 \\
0.00207 \\
0.00077 \\
0.00032\end{array}$ & $\begin{array}{r}1149 \\
4597 \\
11493 \\
22987\end{array}$ & $\begin{array}{c}28.3 \\
9.5 \\
8.8 \\
7.35\end{array}$ \\
\hline $\begin{array}{r}35-37 \\
39-41 \\
41-43 \\
43-45\end{array}$ & $\begin{array}{l}1 \\
1 \\
1\end{array}$ & $\begin{array}{l}.01 \\
.001 \\
.001\end{array}$ & $\begin{array}{r}66 \\
133 \\
133\end{array}$ & $\begin{array}{l}1.63 \\
2.39 \\
0.72\end{array}$ & $\begin{array}{l}0.0163 \\
0.00239 \\
0.00072\end{array}$ & $\begin{array}{r}1149 \\
4597 \\
11493\end{array}$ & $\begin{array}{r}18.7 \\
10.9 \\
8.3\end{array}$ \\
\hline $\begin{array}{r}37-39 \\
41-43 \\
43-45\end{array}$ & $\begin{array}{l}1 \\
1\end{array}$ & $\begin{array}{l}.01 \\
.001\end{array}$ & $\begin{array}{r}66 \\
166\end{array}$ & $\begin{array}{l}2.41 \\
3.09\end{array}$ & $\begin{array}{l}0.0241 \\
0.00309\end{array}$ & $\begin{array}{l}1149 \\
4597\end{array}$ & $\begin{array}{l}27.7 \\
14.2\end{array}$ \\
\hline $\begin{array}{c}39-41 \\
43-45\end{array}$ & 1 & .01 & 66 & 3.50 & 0.0350 & 1149 & 40.2 \\
\hline END: & $\begin{array}{l}=G \\
=G \\
=A\end{array}$ & ric & $\begin{array}{l}\text { tor } \\
\text { stivi }\end{array}$ & $\begin{array}{l}=D \\
=B\end{array}$ & $\begin{array}{l}\text { TX } \\
e^{c o n}\end{array}$ & $\begin{array}{l}\text { t Swi } \\
\text { to nu }\end{array}$ & eter \\
\hline
\end{tabular}


TABLE 10. LINE F.

COLORADO GEOLOGICAL SURVEY

Geophysical Exploration

(Resistivity Survey)

LOCATION

Shaw Springs

CHIEF OPERATOR
PROJECT

Line F

ASSISTANTS

Fargo and Treska
DATE

10 JUTY 1980

METHOD

\section{Jay Jones \\ C}

$\longrightarrow$

MA Voltage $V_{p}$

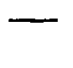

$1-3$

$5-7$

$7-9$

$9-11$

$11-13$

$13-15$

\begin{abstract}
Range
\end{abstract}
.01

.01

.001

.001

.001
3-5

7-9

$9-11$

11-13

13-15

15-17

5-7

9-11

11-13

13-15

15-17

17-19

7-9

$\begin{array}{lllr}11-13 & 1 & .01 & 66 \\ 13-15 & 1 & .001 & 200 \\ 15-17 & 1 & .001 & 200 \\ 17-19 & 1 & .001 & 200 \\ 19-21 & 1 & .001 & 200\end{array}$

9-11

13-15

15-17

17-19

19-21

21-23
.01

.01

.001

.001

.001

.01

.001

.001

.001

.001

66
66
466
466
466

66
100
100
100
100

66

66

100

100

133

66

200

200

200

200
6.00

8.50

2.64

1.29

0.74

0.060

0.00850

0.00264

0.00129

0.00074

7.55

0.85

2.68

1.39

0.75

0.0755

0.0085

0.00268

0.00139

0.00075

5. 35

0.0535

6.21

2.35

1.22

0.61

0.00621

0.00235

0.00122

0.00061

G.F.

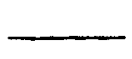

1149

4597

11493

22987

40227

1149

4597

11493

22987

40227

1149

4597

11493

22987

40227

1149

4597

11493

22987

40227

4. 72

5.91

0.0472

0.00591

0.00252

2.52

1.19

0.00119

0.00063

0.63

1149
4597
11493
22987
40227

54

27

29

27

25 
TABLE 10. LINE $F$ (CONT.)

\begin{tabular}{|c|c|c|c|c|c|c|c|}
\hline Sta. & Range & MA & Voltage & $v_{p}$ & $\mathrm{DV} / \mathrm{I}$ & G.F. & $\mathrm{Pa}_{\mathrm{a}}$ \\
\hline $\begin{array}{c}11-13 \\
15-17 \\
17-19 \\
19-21 \\
21-23 \\
23-25\end{array}$ & $\begin{array}{l}1 \\
1 \\
1 \\
1 \\
1\end{array}$ & $\begin{array}{l}.01 \\
.001 \\
.001 \\
.001 \\
.001\end{array}$ & $\begin{array}{r}66 \\
133 \\
133 \\
133 \\
133\end{array}$ & $\begin{array}{l}2.90 \\
5.70 \\
2.31 \\
1.13 \\
0.65\end{array}$ & $\begin{array}{l}0.0290 \\
0.00570 \\
0.00231 \\
0.00113 \\
0.00065\end{array}$ & $\begin{array}{r}1149 \\
4597 \\
11493 \\
22987 \\
40227\end{array}$ & $\begin{array}{l}33 \\
26 \\
27 \\
26 \\
26\end{array}$ \\
\hline $\begin{array}{c}13-15 \\
17-19 \\
19-21 \\
21-23 \\
23-25 \\
25-27\end{array}$ & $\begin{array}{l}1 \\
1 \\
1 \\
1 \\
1\end{array}$ & $\begin{array}{l}.01 \\
.001 \\
.001 \\
.001 \\
.001\end{array}$ & $\begin{array}{r}66 \\
100 \\
100 \\
100 \\
100\end{array}$ & $\begin{array}{l}2.06 \\
5.14 \\
2.25 \\
1.16 \\
0.65\end{array}$ & $\begin{array}{l}0.0206 \\
0.00514 \\
0.00225 \\
0.00116 \\
.00065\end{array}$ & $\begin{array}{r}1149 \\
4597 \\
11493 \\
22987 \\
40227\end{array}$ & $\begin{array}{l}24 \\
24 \\
26 \\
27 \\
26\end{array}$ \\
\hline
\end{tabular}

$15-17$

\begin{tabular}{|c|c|c|c|c|c|c|}
\hline $\begin{array}{l}19-21 \\
21-23 \\
23-25 \\
25-27 \\
27-29\end{array}$ & $\begin{array}{l}1 \\
1 \\
1 \\
1 \\
1\end{array}$ & $\begin{array}{l}.01 \\
.001 \\
.001 \\
.001 \\
.001\end{array}$ & $\begin{array}{r}66 \\
100 \\
100 \\
100 \\
100\end{array}$ & $\begin{array}{l}1.64 \\
5.28 \\
2.40 \\
1.24 \\
0.60\end{array}$ & $\begin{array}{l}0.0164 \\
0.00528 \\
0.00240 \\
0.00124 \\
0.00060\end{array}$ & $\begin{array}{r}1149 \\
4597 \\
11493 \\
22987 \\
40227\end{array}$ \\
\hline
\end{tabular}

$17-19$

$21-23$

$23-25$

$25-27$

$27-29$

29-31

$\begin{array}{rrr}1 & .01 & 66 \\ 1 & .001 & 100 \\ 1 & .001 & 100 \\ 1 & .001 & 100 \\ 1 & .001 & 100\end{array}$

1.73

0.0173

1149

5.75

0.00575

4597

2.58

0.00258

11493

1.15

0.00115

22987

$0.00075 \quad 40227$

24

28

28

29

19-21

$23-25$

25-27

$27-29$

29-31

$31-33$

$\begin{array}{rlr}1 & .01 & 66 \\ 1 & .001 & 133 \\ 1 & .001 & 133 \\ 1 & .001 & 133 \\ 1 & .001 & 133\end{array}$

1.84

6.21

0.0184

0.00621

1149

2. 50

0.00250

4597

1.20

0.00120

11493

22987

20

26

30

26

30

$21-23$

25-27

27-29

0.65

0.00065

40227

21

29

29

28

26

29-31

.01

66

1.95

0.0195

1149

22

6.24

0.00624

4597

2.63

0.00263

11493

1.18

0.00118

22987

0.51

0.00051

40227

29

30

$\begin{array}{ll}.001 & 200 \\ .001 & 200\end{array}$

2.16

.021

1149

25

27-29

.01

66

7.05

0.00705

4597

11493

32

$33-35$

200

2.78

0.00278

$\begin{array}{ll}0.00110 & 22987 \\ 0.00052 & 40227\end{array}$

1.10
0.52

32
25

200

0.00052

21 
TABLE 10. LINE $F$ (CONT.)






\author{
APPENDIX H \\ TABLE 11 \\ GEOMETRIC FACTOR TABLE \\ SCHLUMBERGER METHOD
}

\begin{tabular}{|c|c|c|c|c|c|c|}
\hline$L(f t)$ & 25 & 50 & 75 & 100 & 200 & 300 \\
\hline 50 & 95.78 & 47.89 & 31.93 & 23.94 & 11.97 & 7.98 \\
\hline 75 & 215.5 & 107.75 & 71.83 & 53.87 & 26.94 & 17.96 \\
\hline 100 & 383.11 & 191.55 & 127.70 & 95.78 & 47.89 & 31.93 \\
\hline 200 & 1532.44 & 766.22 & 510.81 & 383.11 & 191.56 & 127.70 \\
\hline 300 & 3447.99 & 1724 & 1149.33 & 862 & 431 & 287.33 \\
\hline 400 & 6129.87 & 3064.89 & 2043.26 & 1532.44 & 766.22 & 510.81 \\
\hline 500 & 9577.77 & 4788.89 & 3192.59 & 2394.44 & 1197.22 & 798.15 \\
\hline 600 & 1391.99 & 6896 & 4597.33 & 3447.99 & 1724 & 1149.33 \\
\hline 700 & 18772.43 & 9386.22 & 6257.48 & 4693.11 & 2346.55 & 1564.37 \\
\hline 800 & 24519.1 & 12259.54 & 8173.03 & 6129.77 & 3064.89 & 2043.26 \\
\hline 900 & 31031.99 & 15515.99 & 10344 & 7758 & 3879 & 2586 \\
\hline 1000 & 38311.1 & 19155.55 & 12770.36 & 9577.77 & 4788.89 & 3192.59 \\
\hline 1100 & 46356.42 & 23178.21 & 15452.14 & 11589.11 & 5794.55 & 3863.04 \\
\hline 1200 & 55167.97 & 27583.99 & 18389.32 & 13791.99 & 6896 & 4597.33 \\
\hline 1300 & 64745.74 & 32372.87 & 21581.91 & 16186.44 & 8093.22 & 5395.48 \\
\hline 1400 & 75083.74 & .87 & 25029.91 & 18772.44 & 9386.22 & 6257.48 \\
\hline 1500 & 86199.96 & 43099.98 & 28733.32 & 21548.98 & 10774.99 & 7183.3 \\
\hline
\end{tabular}

TABLE 12. DIPOLE-DIPOLE GEOMETRIC FACTOR TABLE

\begin{tabular}{rccrrrr} 
na $(\mathrm{ft})$ & \multicolumn{1}{c}{25} & 50 & 100 & 150 & \multicolumn{1}{c}{200} & \multicolumn{1}{c}{300} \\
\cline { 2 - 6 } 1 & 143.67 & 287.33 & 574.67 & 862 & 1149.33 & 1724 \\
2 & 574.67 & 1149.32 & 2298.67 & 3448 & 4597.32 & 6896 \\
3 & 1436.7 & 2873.3 & 5746.7 & 8620 & 11493.3 & 17240 \\
4 & 2873.4 & 5746.6 & 11493.4 & 17240 & 22986.6 & 3480 \\
5 & 5028.45 & 1056.55 & 20113.45 & 30170 & 40226.55 & 60340 \\
6 & 8045.52 & 16090.48 & 32181.52 & 48272 & 64362.48 & 96544 \\
7 & 11924.61 & 23848.39 & 47697.61 & 71546 & 95394.39 & 143092 \\
8 & 17240.4 & 34479.6 & 68960.4 & 103440 & 137913.6 & 206880 \\
9 & 23705.55 & 47409.45 & 94820.55 & 14230 & 189639.45 & 284460 \\
10 & 31607.4 & 63212.6 & 126429.4 & 189640 & 252852.6 & 379280
\end{tabular}

TABLE 13. WENNER GEOMETRIC FACTOR TABLE

\begin{tabular}{|c|c|c|c|c|c|c|c|}
\hline $2 \operatorname{II} a(f t)$ & 25 & 50 & 100 & 200 & 300 & 400 & 500 \\
\hline 6.2 & 157 & 314.16 & 628.32 & 1256.64 & 1884.64 & 2513.27 & 3141.6 \\
\hline
\end{tabular}



Special Pub. 10, HYDROGEOLOGICAL AND GEOTHERMAL INVESTIGATIONS OF PAGOSA SPRINGS, COLORADO, by M.A. Galloway WITH A SECTION ON MINERALOGICAL AND PETROGRAPHIC INVESTIGATIONS OF. SAMPLES FROM GEOTHERMAL WELLS 0-1 AND P-1, PAGOSA SPRINGS, COLORADO, by W.W. Atkinson, $1980,95 \mathrm{p} . \$ 10.00$

Special Pub. 16, GEOTHERMAL RESOURCE ASSESSMENT OF WAUNITA HOT SPRINGS, COLORADO, ed. by T. G. Zacharakis, $1981,69 \mathrm{p}$., Free over the counter.

Special Pub. 18, GROUNDWATER HEAT PUMPS IN COLORADO, AN EFFICIENT AND COST EFFECTIVE WAY TO HEAT: AND COOL YOUR HOME, by K.L. Garing and F.R. Connor, 1981,32 p., Free over the counter.

Map Series 14, GEOTHERMAL RESOURCES OF COLORADO, by R.H. Pearl, Scale 1:500,000, Free over the counter.

Map Series 18, REVISED HEA'T FLOW MAP OF COLORADO, by T.G. Zacharakis, Scale 1:1,000,000, Free over the counter.

Map Series 20, GEOTHERMAL GRADIENT MAP OF COLORADO, by F.N. Repplier and R.L. Fargo, 1981, Scalle 1: 1,000,000, Free over the counter.

Info. Series 4, MAP SHOWING THERMAL SPRINGS, WELLS, AND HEAT FLOW CONTOURS IN COLORADO, by J.K. Barrett, R.H. Pearl and A.J. Pennington, 1976, Scale 1:1,000,000, out of print.

Info. Series 6, HYDROGEOLOGICAL DATA OF THERMAL SPRINGS AND WELLS IN COLORADO, by J.K. Barrett and R.H. Pearl, 1976, 124 p. $\$ 4.00$

Info. Series 9, GEOTHERMAL ENERGY DEVELOPMENT IN COLORADO, PROCESSES, PROMISES AND PROBLEMS, by B.A. Coe, 1978, $51 \mathrm{p} ., \$ 3.00$

Info. Series 15 , REGULATION OF GEOTHERMAL ENERGY DEVELOPMENT IN COLORADO, by B.A. Coe and N.A. Forman, 1980, Free over the counter.

Open-File Report 80-10, GEOTHERMAL POTENTIAL IN CHAFFEE COUNTY, COLORADO, by. F.C? Healy, $47 \mathrm{p}$ !, Free over the counter.

(8)

Open-File Report 80-11, COMMUNITY DEVELOPMENT OF GEOTHERMAL ENERGY IN PAGOSA SPRINGS, COLORADO, by B.A. Coe, 1980, Free over the counter.

Open-File Report 80-12, TEMPERATURE-DEPTH PROFILES IN THE SAN LUIS VALLEY AND CANON CITY AREA, COLORADO, by C.D. Ringrose, Free over the counter.

Open-File Report 80-13, GEOTHERMAL ENERGY POTENTIAL IN THE SAN LUIS VALLEY, COLORADO, by B.A. Coe, $1980,44 \mathrm{p}$. . Free over the counter.

Open-File Report 81-2, GEOTHERMAL ENERGY OPPORTUNITIES AT FOUR COLORADO. TOWNS, by B.A. Coe and Judy Zimmerman, 1981, Free over the counter.

Open-File Report $81-3$, APPENDICES OF AN APPRAISAL FOR THE USE OF GEOTHERMAL ENERGY IN STATE-OWNED BUILDINGS IN COLORADO: SECTION A, Al amOSa; SECTION B, BUENA VISTA; SECTION C, BURLINGTON: SECTION D, DURANGO; SECTION E, GLENWOOD SPRINGS; SECTION F, STEAMBOAT SPRINGS, $1981, \$ 1.50$ each or $\$ 8.00$ for the set.

Pamphlet, GEOTHERMAL ENERGY-COLORADO'S UNTAPPED RESOURCE, Free over the counter.

In addition to the above charges there is an additional charge for all mail orders. Contact the colorado Geol. Survey for exact amount. To order publications specify series and number, title and quantity desired. Prepayment is required. Make Checks payable to: Colorado Geological Survey, Rm. 7.15, 1313 Sherman St., Denver, Colorado 80203 (303/866-2611). 
Following is a list of publications relating to the geothermal energy resources of Colorado published by the Colorado Geological Survey.

BU11. 11, MINERAL WATERS OF COLORADO, by R.D. George and others, 1920 , 474 P., out of print.

BU11. 35, SUMMARY OF GEOLOGY OF COLORADO RELATED TO GEOTHERMAL ENERGY POTENTIAL, PROCEEDINGS OF A SYMPOSI UM ON GEOTHERMAL ENERGY AND COLORADO, ed. by R.H. Pearl, $1974, \$ 3.00$

BU1 1. 39, AN APPRAISAL OF COLORADO'S GEOTHERMAL RESOURCES, by J.K. Barrett and R.H. Pearl, 1978,224 P., $\$ 7.00$

BU11. 44, BIBLIOGRAPHY OF GEOTHERMAL REPORTS IN COLORADO, by R. H. PearI, T.G.Zacharakis, F.N. Reppl Ier and K.P. MCCarthy, 1981, 24 p, $\$ 2.00$.

Resource Ser. 6, COLORADO'S HYDROTHERMAL RESOURCE BASE-AN ASSESSNENT, by R.H. Pearl, $1979,144 \mathrm{p},, \$ 2.00$.

Resource Ser. 14, AN APPRAISAL FOR THE USE OF GEOTHERMAL ENERGY IN STATE OWNED BUILOINGS IN COLORADO, by R.T. Meyer, B.A. COE and J.D. Dick, $1981,63 \mathrm{p}, \$ 5.00$.

Re source Ser, 15, GEOTHERMAL RESOURCE ASSESSMENT DF OURAY, COLORADO, by T.G. Zacharakis, C.D. Ringrose and R.H. Pear 1, 1981, 70 p., Free over the counter.

Resource Ser. 16, GEOTHERMAL RESOURCE ASSESSMENT OF IDAHO SPRINGS, COLORADO. by F.N. Repplier, T.G. Zacharakis, and C.D. Ringrose, 1982, Free over the counter.

Re sourCe Ser. 17, GEOTHERMAL RESNURCE ASSESSMENT OF THE ANIMAS VALLEY, COLORADO, by K.P. MCCarthy,.J.G. Zacharakis and C.D. Bingrose, 1982 , Free over the counter.

Resource Ser 18 , GEOTHERMAL RESOURCE ASSESSMENT OF HARTSEL, COLORADO, by K.P. McCarthy, T.G. Zacharakis, and R.H. Pearl, 1982, Free over the counter.

Resource Ser, 19, GEOTHERMAL RESOURCE ASSESSMENT OF WESTERN SAN LUIS VALLEY, by T.G. Zahcarakis, R.H. Pearl and C.D. Ringrose, 1982, Free over the counter.

Resource Ser. 20, GEOTHERMAL RESOURCE ASSESSMENT OF CANON CITY AREA, COLORADO, BY T.G. Zacharakis and R. H. Pear1, 1982, Free over the counter.

Resource Ser. 22, GEOTHERMAL RESOURCE ASSESSMENT OF STEAMBOAT SPRINGS AREA, COLORABO, by R.H. Pear1, T.G. Zacharakis and C.D. Ringrose, 198:2, Free over the counter.

Ré source Ser. 23, GEOTHERIML RESOURCE ASSESSMENT OF HOT SULPHUR SPRINGS, COLORADO, by R.H. Pearl, T.G. Zacharkis and C.D. Ringrose 1982 , Free over the counter.

Re sourCe Ser 24, GEOTHERMAL RESOURCE ASSESSMENT OF RANGER HOT SPRINGS, COLORADO, by T.G. Zacharakis and R.H. Pear1, 1982, Free over the counter.

Special Pub. 2, GEOTHERMAL RESOURCES OF COLORADO, by R.H. Pear1, 1972, 54 p. $\$ 2.00$.

(CONTINUED ON INSIDE OF BACK COVER) 